\title{
Trace elements at the intersection of marine biological and geochemical evolution
}

Leslie J. Robbins ${ }^{1 *}$, Stefan V. Lalonde ${ }^{2}$, Noah J. Planavsky ${ }^{3}$, Camille A. Partin ${ }^{4}$, Christopher T. Reinhard ${ }^{5}$, Brian Kendall ${ }^{6}$, Clint Scott ${ }^{7}$, Dalton S. Hardisty ${ }^{8}$, Benjamin C. Gill $^{9}$, Daniel S. Alessi ${ }^{1}$, Christopher L. Dupont ${ }^{10}$, Mak A. Saito ${ }^{11}$, Sean A. Crowe ${ }^{12,13}$, Simon W. Poulton ${ }^{14}$, Andrey Bekker ${ }^{15,16}$, Timothy W. Lyons ${ }^{15}$, Kurt O. Konhauser ${ }^{1}$

${ }^{1}$ Department of Earth and Atmospheric Sciences, University of Alberta, Edmonton, AB T6G 2E3, Canada

${ }^{2}$ European Institute for Marine Studies, CNRS-UMR6538 Laboratoire Domaines Océaniques, Technopôle Brest-Iroise, 29280 Plouzané, France

${ }^{3}$ Department of Geology and Geophysics, Yale University, New Haven, CT 06520, USA

${ }^{4}$ Department of Geological Sciences, University of Saskatchewan, Saskatoon, SK S7N 5E2, Canada

${ }^{5}$ School of Earth and Atmospheric Sciences, Georgia Institute of Technology, Atlanta, GA 30332, USA

${ }^{6}$ Department of Earth and Environmental Sciences, University of Waterloo, Waterloo, ON, Canada

${ }^{7}$ United States Geological Survey, National Center, Reston, VA 20192, USA

${ }^{8}$ Department of Geology and Geophysics, Woods Hole Oceanographic Institution, Woods Hole, MA 02542

${ }^{9}$ Department of Geosciences, Virginia Polytechnic Institute and State University, Blacksburg, VA 24061, USA

${ }^{10}$ Microbial and Environmental Genomics Group, J. Craig Venter Institute, La Jolla, CA 92121, USA

${ }^{11}$ Marine Chemistry and Geochemistry Department, Woods Hole Oceanographic Institution, Woods Hole, MA 02543, USA

${ }^{12}$ Department of Microbiology and Immunology, University of British Columbia, Vancouver, BC V6T 1Z3, Canada

${ }^{13}$ Department of Earth, Ocean, and Atmospheric Sciences, University of British Columbia, Vancouver, BC V6T 1Z3, Canada

${ }^{14}$ School of Earth and Environment, University of Leeds, Leeds LS2 9JT, UK

${ }^{15}$ Department of Earth Sciences, University of California Riverside, Riverside, CA 92521, USA

${ }^{16}$ Department of Geology, University of Johannesburg, P.O. Box 524, Aukland Park, 2006, South Africa

*corresponding author: Leslie J. Robbins, Department of Earth and Atmospheric Sciences, University of Alberta, 1-26 University of Alberta, Edmonton, AB, Canada Phone: 1-780-492-6532,Email: 1robbins@ualberta.ca 


\begin{abstract}
Life requires a wide variety of bioessential trace elements to act as structural components and reactive centers in metalloenzymes. These requirements differ between organisms and have evolved over geological time, likely guided in some part by environmental conditions. Until recently, most of what was understood regarding trace element concentrations in the Precambrian oceans was inferred by extrapolation, geochemical modeling, and/or genomic studies. However, in the past decade, the increasing availability of trace element and isotopic data for sedimentary rocks of all ages have yielded new, and potentially more direct, insights into secular changes in seawater composition - and ultimately the evolution of the marine biosphere. Compiled records of many bioessential trace elements (including $\mathrm{Ni}, \mathrm{Mo}, \mathrm{P}, \mathrm{Zn}, \mathrm{Co}, \mathrm{Cr}$, Se, and I) provide new insight into how trace element abundance in Earth's ancient oceans may have been linked to biological evolution. Several of these trace elements display redox-sensitive behavior, while others are redox-sensitive but not bioessential (e.g., Cr, U). Their temporal trends in sedimentary archives provide useful constraints on changes in atmosphere-ocean redox conditions that are linked to biological evolution, for example, the activity of oxygen-producing, photosynthetic cyanobacteria. In this review, we summarize available Precambrian trace element proxy data, and discuss how temporal trends in the seawater concentrations of specific trace elements may be linked to the evolution of both simple and complex life. We also examine several biologically relevant and/or redox-sensitive trace elements that have yet to be fully examined in the sedimentary rock record (e.g., $\mathrm{Cu}, \mathrm{Cd}, \mathrm{W}$ ) and suggest several directions for future studies.
\end{abstract}


Key words: Iron formations, black shales, eukaryotes, prokaryotes, evolution, trace elements, biolimitation, Precambrian

\section{Introduction}

The trace elements utilized in metalloenzymes today are commonly thought to reflect, to some degree, the availability of trace elements in ancient seawater when those metalloenzymes first evolved. It was first realized in 1988 that trace metal availability exerted significant control over phytoplankton productivity (Martin and Fitzwater, 1988). In the mid 1990's, as part of the first edition of their seminal book, Frausto da Silva and Williams (2001) suggested that a cell's trace element inventory was directly related to the conditions under which the host organism evolved. This profound suggestion, along with increasing recognition that trace element availability exerted control on primary productivity and other metabolic activities, stimulated a new generation of studies examining trace element use and limitation in marine microorganisms (e.g., Sunda and Huntsman, 1995; Saito et al., 2002). Indeed, Sunda and Huntsman (1995) arguably provide the first experimental evidence for absolute Co requirements in cyanobacteria.

The idea that an organism's trace element requirements are dependent on the environment in which it evolved stems from the simple observation that the biogeochemical cycling of many bioessential elements can vary dramatically under different aqueous conditions (see also Williams and Rickaby, 2012). In this light, some trace element limitations observed in the modern ocean might be thought of as an evolutionary legacy of earlier life adapted to more replete conditions. This idea is easily 
illustrated with iron, which is the most common metal co-factor and a limiting micronutrient in large regions of the oceans today, especially high-nutrient low chlorophyll (HNLC) regions (for reviews see Zahariev et al., 2008; Moore et al., 2013). By contrast, iron would have been much more abundant in surface waters on a more reducing Earth when basic microbial metabolic machinery was being established (e.g., Poulton and Canfield, 2011; David and Alm, 2011). Thus, modern iron demand can be thought of as an evolutionary relict, stemming from the emergence of lineages under ancient environmental conditions of relative Fe abundance. The leading alternative to this model is that organismal elemental requirements are driven almost entirely by utility, i.e., cellular function, with shifts in biological requirements decoupled from corresponding environmental abundances (Scott et al., 2013; Robbins et al., 2013; Stüeken et al., 2015a). Some continuum likely exists between these two scenarios.

If biological trace element requirements are related to changes in their paleoseawater concentrations, then comparative microbial phylogenomics should provide some insight into paleomarine chemistry. Zerkle et al. (2005) surveyed multiple microbial genomes to track the distribution of metalloenzymes in prokaryotes over geological time and evaluated biogeochemical signatures from which inferences about paleomarine trace element concentrations could be made. Further, Zerkle et al. (2005) proposed an evolutionary trajectory for the use of several metals in metalloenzymes, highlighting instances that matched inferred seawater chemistry and several that did not. Using an alternative approach, Dupont et al. (2006) examined the diversification of structural domains in metal-binding proteins across modern proteomes, and similarly suggested that their trace element evolutionary path tracks to some degree changes in paleomarine 
geochemistry. Dupont et al. (2010) furthered this idea by linking increased atmosphereocean oxygenation during the late Neoproterozoic to increased reliance on certain bioessential trace metals, such as $\mathrm{Zn}, \mathrm{Cu}$, and Mo. This transition, in turn, may have been a contributing factor to the evolution and diversification of eukaryotes at that time. In at least one case, careful examination of the rock record reveals that biological innovation, rather than evolving marine trace element concentrations, may have guided biological dependency (Zn, c.f. section 3.4; Scott et al., 2012; Robbins et al., 2013). As both these studies indicate a relatively constant marine reservoir of $\mathrm{Zn}$, the rapid proliferation observed in Zn metalloenzymes in the Neoproterozoic (e.g., Dupont et al., 2010) may instead be attributable to the utility of $\mathrm{Zn}$ in eukaryotic metalloenzymes rather than evolving environmental conditions (see also section 4.4).

Regardless of which factors have shaped the elemental stoichiometry of microorganisms, constraining trace element abundances in seawater through time is of paramount importance for understanding the evolution of marine biogeochemistry on a mechanistic level. The potential for evolving marine geochemistry to affect the bioavailability of biologically critical trace elements was popularized, at least from an Earth Sciences perspective, by Anbar and Knoll (2002). These authors proposed that Proterozoic ocean chemistry and biological evolution may be viewed as linked via a 'bioinorganic bridge', whereby high concentrations of dissolved sulfide in the marine environment during much of the Proterozoic limited the bioavailability of critical trace elements in seawater, such as Mo. This not only had a negative impact on global primary productivity, but it delayed the evolution of early eukaryotes. Not surprisingly, there has been an increased focus in recent years on exploring Precambrian sedimentary rocks for 
direct proxies of paleomarine chemistry and redox conditions. Much of this work has been directed towards the iron formation (IF), black shale, and pyrite records of the marine paleoenvironment; although carbonates also provide important information, their complex diagenetic histories and susceptibility to overprinting complicates their use.

As iron- and silica-rich chemical sedimentary deposits, IF have proven useful because the trace metal content in the least metamorphosed units are almost entirely derived from seawater (see Bjerrum and Canfield, 2002; Konhauser et al., 2007; 2009; 2015; Robbins et al., 2013). This is further supported by intense filtering of the IF record to remove samples showing indications of detrital inputs (e.g., $>1 \% \mathrm{Al}_{2} \mathrm{O}_{3}$ or $>0.1 \%$ $\mathrm{TiO}_{2}$; see Konhauser et al., 2009, 2011; Robbins et al., 2013; Partin et al., 2013a; Swanner et al., 2014 for further discussion). Therefore, it is thought that their chemical composition directly reflects availability in the water column at the time of mineral precipitation and deposition.

Another powerful source of information is the shale record, especially organic matter-rich, fine-grained, siliciclastics (with $>0.5 \mathrm{wt} \%$ total organic carbon, TOC), which are attractive because (1) they have modern analogues in anoxic basins (e.g., Black Sea, Cariaco Basin), (2) they provide a more continuous temporal record since shale is relatively common in the geologic record, (3) several trace elements (e.g., Mo, U) are known to scale with organic carbon during deposition and burial in euxinic water columns (Algeo and Lyons, 2006), and (4) a direct relationship between concentrations in organic-rich sediments and dissolved concentrations in overlying anoxic and sulfidic bottom waters has been demonstrated for some trace elements (e.g., Mo, Zn; Algeo and Lyons, 2006; Scott et al., 2013). 
Recently, several other sedimentary rock types are receiving increased attention for their trace element proxy potential, including chert (Baldwin et al., 2011) and diagenetic pyrite (e.g., Swanner et al., 2013; 2014; Large et al., 2014; Gallagher et al., 2015). Each of these archives has the potential to provide unique insights into past marine trace element concentrations, but as outlined below, they also have obvious limitations.

The IF and shale trace element records published to date generally support the idea that redox chemistry played a central role in the evolution of marine elemental cycling, with two particular events standing out: the Great Oxidation Event (GOE) 2.4 billion years ago $(\mathrm{Ga})$, and the Neoproterozoic oxygenation event (NOE) $\sim 0.7 \mathrm{Ga}$. The GOE represents the permanent rise of oxygen to above $10^{-5}$ of present atmospheric levels [PAL], an upper limit for the production of large isotopic signatures by sulfur massindependent fractionation (S-MIF) (Pavlov and Kasting, 2002) that effectively disappeared from the sedimentary record between 2.45 and 2.32 Ga (e.g., Bekker et al., 2004; Farquhar et al., 2000; 2011). Recent studies based on the trace element proxies of $\mathrm{Cr}$ and $\mathrm{U}$, as indicators for continental oxidative weathering have pushed the onset of the GOE back to 2.48-2.47 Ga (Konhauser et al. (2011) and Partin et al. (2013a), respectively. The period surrounding the GOE is likely better thought of as a long-lived dynamic transition rather than a discrete event (Lyons et al., 2014a). However, for the purpose of this review, we will refer to the age of the GOE as $\sim 2.4 \mathrm{Ga}$.

In this review, we first provide a brief description of the geochemical modeling (Fig. 1) and genomic work done thus far, as well as the IF and black shale records, highlighting the features that make trace elements useful as paleomarine proxies. Subsequently, we discuss several bioessential trace elements in the order in which they 
were first explored in the literature. Finally, we identify several trace elements that have yet to be investigated in detail and, in this light, outline several opportunities for future work. Although the primary purpose of this paper is to review our knowledge of the records of trace element evolution in seawater, we will also highlight trace metal evidence for Earth's protracted redox evolution. Given the control exerted on many metals by the prevailing redox condition and the requirement of oxygen for complex life to evolve, these trace metal redox signals speak directly to the activity of the biosphere, and more specifically that of photosynthetic cyanobacteria.

\subsection{Evidence for early life}

It is now generally accepted that life evolved relatively early in Earth history, with putative evidence pointing to the existence of a biosphere as early $4.1 \mathrm{Ga}$ (see Bell et al., 2015) and more convincingly by $3.7 \mathrm{Ga}$. The evidence for early life comes in a variety of forms that include ${ }^{13} \mathrm{C}$-depleted organic carbon residues (e.g., Mojzsis et al., 1996; Rosing, 1999; Rosing and Frei, 2004; McKeegan et al., 2007), microfossils (e.g., Schopf and Packer, 1987; Schopf, 1993; 2006), purported ichnofossils (Furnes et al., 2004; Banerjee et al., 2006; 2007), stromatolites or other microbially induced sedimentary structures (MISS) (Walter et al., 1980; Hofmann et al., 1999; Grotzinger and Knoll, 1999; Allwood et al., 2006; Van Kranendonk et al., 2003; 2008; Heubeck, 2009; Noffke, 2009; Noffke et al., 2013; Nutman et al., 2016), and molecular biomarkers (Brocks et al., 1999; 2003a,b,c; Eigenbrode and Freeman, 2006; Waldbauer et al., 2009). Each of these indicators for early life has been challenged, generally by invoking abiogenic mechanisms or contamination by younger material to explain their origins (e.g., carbon 
isotopes: van Zuilen et al., 2002; Lepland et al., 2011; microfossils: Brasier et al., 2002; Garcia-Ruiz et al., 2003; ichnofossils: Grosch and McLoughlin, 2014; stromatolites: Lowe, 1994; biomarkers: Rasmussen et al., 2008; French et al., 2015). Despite these challenges, however, there is a growing consensus that favors an origin of life on Earth before $\sim 3.5 \mathrm{Ga}$, and perhaps much earlier.

For reasons still debated, complex animal life did not evolve until almost three billion years later in the Neoproterozoic (e.g., Pecoits et al., 2012). Following the evolution of stem group eukaryotes in the early mid-Proterozoic (Butterfield, 2000; Knoll, 2014), there is a relatively static period in eukaryotic diversity lasting from 1.8 to $0.8 \mathrm{Ga}$. This relative evolutionary stasis was punctuated by two critical events that occurred in relatively short order: first, the evolution of metazoans in the Cryogenian (e.g., Love et al., 2009; Erwin et al., 2011), and second, the rapid diversification of complex animal life in the Ediacaran and into the Cambrian - although this event also likely has roots in the Cryogenian (Fedonkin, 2003; Love et al., 2009; Erwin et al., 2011). This billion-year stagnation in eukaryotic diversification is often attributed to the late rise of atmospheric oxygen (e.g., Nursall, 1959; Knoll and Carrol, 1999; Fedonkin, 2003; Planavksy et al., 2014a) to levels required by metazoans (i.e. 0.5\% to 4\% PAL; Mills et al., 2014). Recent work by Mills et al. (2014), however, suggests that primitive metazoans, such as sponges, may have needed very little oxygen in the water column in order to thrive. Additionally, changes in the availability of critical trace elements (Fig. 1 and 2) - themselves linked to the evolving redox state of the Earth - have been suggested to have influenced eukaryotic diversification (e.g., Anbar and Knoll, 2002; Williams and Frausto da Silva, 2003; Saito et al., 2003; Dupont et al., 2010; Williams and Rickaby, 
2012). The slow rate of eukaryotic evolution, limited variation in the carbon isotope record (e.g., Brasier and Lindsay, 1998), and a paucity of evidence for glaciation on Earth during this time period (Eyles and Young, 1994) have ultimately led to the midProterozoic (1.8 to $0.8 \mathrm{Ga}$ ) being termed the 'boring billion' (e.g., Brasier and Lindsay 1998).

As life likely emerged in the Eoarchean $(4.1-3.7 \mathrm{Ga})$, it would have been subjected to geochemical conditions in the oceans that were fundamentally different to those present today. Earth's history has been marked by the advent of plate tectonics, growth of the continental crust, and protracted oxygenation of the atmosphere-ocean system — among other fundamental transitions. All these events likely had major impacts on seawater chemistry. To understand the interplay between ocean chemistry and the emergence and diversification of life, it is necessary to examine both predictive models for ancient ocean chemistry and the chemical record of ancient sedimentary rocks. Accordingly, such efforts can be divided into the two broad areas emphasized in the review: (1) modeling, cultures, and modern observations, and (2) the sedimentary proxy records.

\section{Modeling and experimental views on trace element limitations}

\subsection{Geochemical and biological modeling approaches}

The notion that changes in seawater composition (Figs. 1 and 2) drove evolution was initially championed in the works of Frausto da Silva and Williams (e.g., Frausto da Silva and Williams, 2001; Williams and Frausto da Silva, 2002; 2003; 2004). In their 2001 book The Biological Chemistry of the Elements, Frausto da Silva and Williams suggested 
that trace element concentrations could have been significantly different on the early Earth (Fig. 2) and that trace element bioavailability may have been controlled by changes in the paleomarine concentration of dissolved sulfide. They pointed to the biological utilization of $\mathrm{Ni}$ and $\mathrm{Co}$ as examples, suggesting that prokaryotes evolved in a reducing environment where these trace elements could have acted as catalysts for early metabolisms, consistent with their use in methanogenesis and by hyperthermophiles. The idea that evolution could be chemically constrained was furthered by Williams and Frausto da Silva (2003) who suggested that changes in mineral solubility may have driven increasing availability of trace elements, such as $\mathrm{V}, \mathrm{Cu}$, and $\mathrm{Zn}$ (amongst others), as the Earth became more oxidizing (Fig. 2). Williams and Frausto da Silva (2004) classified the genome, proteome, and environmental chemistry as "the trinity of life", inextricably linking these three factors to biological evolution. A more recent view of this work has been provided by Williams and Rickaby (2012), where they further suggested that organisms may be grouped into chemotypes depending on similarities in their trace metal requirements.

Saito et al. (2003) modeled the solubility of a suite of biologically essential trace elements ( $\mathrm{Fe}, \mathrm{Mn}, \mathrm{Zn}, \mathrm{Ni}, \mathrm{Cu}, \mathrm{Cd}$, and $\mathrm{Co}$ ) to evaluate plausible concentrations in ancient seawater under ferruginous (anoxic and Fe-rich), euxinic (anoxic and sulfide-rich), and oxic conditions (Fig. 1). The predicted concentrations of trace elements available in the Archean oceans were in line with proposed cyanobacterial nutritional requirements but less so with the eukaryotes, which evolved much later. These authors also found that if Proterozoic oceans were characterized by expanded euxinia (e.g., Canfield, 1998), many of these trace elements (e.g., $\mathrm{Cd}, \mathrm{Cu}, \mathrm{Zn}$ ) could have been drawn down to concentrations 
that were biolimiting. These limitations, in turn, would have effectively attenuated the carbon and oxygen fluxes from the biosphere prior to the extensive oxygenation of the deep oceans in the late Neoproterozoic. Conversely, $\mathrm{Fe}, \mathrm{Mn}, \mathrm{Ni}$, and $\mathrm{Co}$ form weaker aqueous complexes with dissolved sulfide, and are more soluble in metal sulfide form. This would have permitted higher seawater concentrations under anoxic or euxinic conditions relative to $\mathrm{Cd}, \mathrm{Cu}$, and $\mathrm{Zn}$. Following increasing oxygenation in late Neoproterozoic (Canfield et al., 2007; Scott et al., 2008; Sahoo et al., 2012; Lyons et al., 2014a, Planavsky et al., 2014a; Sahoo et al., 2016), these sulfide complexes would have become less abundant, resulting in greater availability of $\mathrm{Cd}, \mathrm{Cu}$, and $\mathrm{Zn}$. Under more oxic conditions first observed in the Cryogenian and continuing to develop into the Cambrian-Ordovician (Large et al., 2014; Sperling et al., 2015; Sahoo et al., 2016), the models of Saito et al. (2003) indicated that Fe and Mn concentrations in seawater would have been drawn down to modern levels as the result of oxide mineral precipitation. This would have presented a challenge for many microbial clades, as Fe is the most common metal co-factor for both prokaryotes and eukaryotes (Dupont et al., 2010). The models of Saito et al. (2003) support the hypothesis that modern cyanobacterial trace element nutrient requirements may be viewed as the direct result of their early evolution in ancient oceans limited in certain trace elements $(\mathrm{Cu}, \mathrm{Cd}, \mathrm{Zn})$ and enriched in others $(\mathrm{Fe}$, $\mathrm{Mn}, \mathrm{Co}, \mathrm{Ni})$. Inverse modeling based on the utilization of trace elements in metalloenzymes (Zerkle et al., 2005) further supports a strong linkage between evolving ocean chemistry and biological trace element dependency. This work suggests that the utilization of trace metals in biology generally follows the pattern of $\mathrm{Fe}>>\mathrm{Zn}>\mathrm{Mn}>>$ $\mathrm{Mo}, \mathrm{Co}, \mathrm{Cu}>>\mathrm{Ni}>\mathrm{W}, \mathrm{V}$. 
Links between the chemical evolution of the early oceans and the trace element complement of organisms are also informed by the emergence or disappearance of metalbinding protein fold families (FF) or fold super families (FSF). Fold families are groups of proteins that are related by structure, function, and sequence, and are considered to have a common evolutionary origin (Dupont et al., 2006). For families whose proteins contain metal-binding domains, it is possible to predict which metals occupy these domains, such that evolutionary relationships between protein structures may be used to reveal trends in metal acquisition in biological systems. The loss or gain of these FF or FSF can be viewed as key evolutionary events that in many cases appear to track fundamental shifts in paleomarine redox chemistry (Dupont et al., 2006; 2010).

Much of the current work focused on trace element proxy records (Fig. 3) has been inspired by the idea that trace metal biolimitation may have been significantly different in the deep past (Javaux et al., 2001; Anbar and Knoll, 2002). In Anbar and Knoll's (2002) 'bio-inorganic bridge', changes in early ocean redox chemistry directly affected the bioavailability of trace elements and, in turn, the evolutionary trajectory of life. Inspired by arguments for widespread marine euxinia during the Mesoproterozoic (1.8-1.0 Ga) (Canfield, 1998), they suggested that such conditions would have limited the seawater Mo reservoir. As nitrogenases containing a Mo-Fe metal cofactor are more efficient than alternative Fe-Fe and V-Fe versions (Eady, 1996), low Mo concentrations would have negatively impacted the ability of primary producers to fix $\mathrm{N}_{2}$. Consequently, Mo limitation could have stifled primary productivity and perhaps even eukaryote evolution (Anbar and Knoll, 2002). 
Indeed, the genomic record for several trace metals has been linked to evolving marine geochemistry. Molybdenum utilization in organisms may have developed in tandem with increasing Mo availability following the early stages of biospheric oxygenation, at which point it became critical to nitrogen fixation (Williams and Frausto da Silva, 2002; 2004; Zerkle et al., 2005; Boyd et al., 2011); although Zerkle et al. (2006) and Glass et al. (2009) have both shown that very low Mo concentrations are capable of supporting near modern levels of nitrogen fixation. Similarly, based on eukaryotic cellular requirements, geochemical modeling, and the late emergence of eukaryotic $\mathrm{Zn}$ metalloenzymes, it was believed that $\mathrm{Zn}$ concentrations in the early oceans would have been a possible barrier to eukaryotic evolution (Williams and Frausto da Silva 2002; 2003; Saito et al., 2003; Dupont et al., 2006; 2010; Williams and Rickaby, 2012). However, recent studies have suggested that the link between trace element availability, utilization, and metallome requirements may have been more complex. For instance, Stüeken et al. (2015a) presented nitrogen isotope data from $\sim 3.0$ Ga sedimentary units suggesting the activity of Mo-Fe nitrogenase, which might indicate that Mo was present at low but physiologically-sufficient levels in the early ocean. This is a scenario supported by the culture studies of Zerkle et al. (2006) and Glass et al. (2009). In the case of $\mathrm{Zn}$, the records of enrichments in both black shales and IFs suggest that the size of the oceanic $\mathrm{Zn}$ reservoir has been relatively constant since the Archean (Scott et al., 2013; Robbins et al., 2013). Thus, in some cases in the deep past, trace elements may have been employed in biological systems despite strongly limiting seawater concentrations (the case of Mo), while in others, sedimentary records are at odds with marine trace metal 
histories suggested by geochemical models and protein structural phylogeny (the case of $\mathrm{Zn})$.

Saito et al. (2003) emphasized that their projections of Precambrian seawater metal concentrations (Fig. 1) are based on thermodynamic models of mineral solubility and speciation in simulated seawater and are thus inherently limited. For many elements, seawater abundances are subject to kinetic controls (e.g., Broecker, 1971) where the dissolved reservoir scales with input/output fluxes without approaching solubility limits. A further limitation is that many of these models assume a homogenous ocean, which is at odds with observations of the modern oceans. In today's oceans, trace element abundances vary both laterally and with depth, and these may vary over several orders of magnitude (Bruland and Lohan, 2003). As well, Moore et al. (2013) have highlighted spatial heterogeneity on a global scale in surface waters with regards to both major limiting nutrients such as nitrate or phosphate, as well as trace metals. Further, studies of ancient environments have already shown that there can be basin scale differences in water column chemistry that as the result of stratification with depth or proximity to shoreline (e.g., Poulton et al., 2010). Given our knowledge regarding spatial variation both in modern oceans and as recorded by the sedimentary record, the assumption of a homogenous ocean is certainly incorrect. However, many aspects of modeling approaches have yet to be fully explored for trace elements in the modern ocean, much less under ancient ocean conditions with dramatically different chemical and redox regimes.

\subsection{Culture experiments and modern environmental observations}


A number of studies have utilized either pure cultures, industrial samples, or natural environments to test and examine the limiting effects of trace metals on biology; for a comprehensive example we draw the reader's attention to Glass and Orphan (2012) who discuss the trace metal limitations of methanogens and methanotrophs. In modern marine environments, Morel and Price (2003) have demonstrated how plankton are able to utilize very low levels of trace metals via complexing ligands that likely evolved to be highly efficient at extracting low levels of these micronutrients from seawater. As well, Morel (2008) related the elemental stoichiometry of modern phytoplankton to the cycling of trace elements in the oceans, and further suggested that the trace metal cycles may have been affected by the advent of strong biological recycling in order to fulfill microbial needs.

Several critical ideas may be gleaned from these reviews and the works that they are based on. First, although trace metals may be biolimiting, levels vary between different organisms, and a universally biolimiting concentration for trace metals may not exist. Second, most prokaryotes and single celled eukaryotes seem to favor trace metal concentrations on the order of $\mathrm{nM}$ to $\mu \mathrm{M}$ levels. Indeed, Glass and Orphan (2012) discuss how the production of methane can be stimulated by the addition of $0.2-2 \mu \mathrm{M}$ of trace metals such as $\mathrm{Fe}, \mathrm{Cu}$, or $\mathrm{Mo}$ to some methanogen communities. In laboratory cultures with freshwater cyanobacteria, Zerkle et al. (2006) suggest that nitrogen assimilation through molybdenum-nitrogenase can occur at Mo levels as low as $5 \mathrm{nM}$, suggesting that these enzymes can be active over a broad range of concentrations. Third, trace metal concentrations do have an upper limit, after which they become toxic as opposed to being beneficial for the organism. Finally, given the low levels of trace metals in modern 
oceans, organisms have had to develop strategies for dealing with the possibility of micronutrient limitation (e.g., Morel and Price, 2003; Morel, 2008). This may include the development of siderophores to assist in scavenging any Fe present, or even the exclusion of certain trace metals traditionally used in a metalloenzymes in favor of a metal free variety. Such strategies lead to the question of whether they are a more recent development or a hold-over from evolution in an ocean with similarly low levels of trace metals, effectively comparable to modern? Ongoing research in these areas will be fundamental to understanding microbial evolution and our interpretation of the sedimentary record.

\section{Proxy records}

\subsection{Traditional proxy records for redox conditions}

Two more traditional and key proxy records that have informed our understanding of the Earth's redox evolution include S-MIF and Fe speciation. Increasingly, these are being augmented with metal stable isotopes, such as Mo and $\mathrm{Cr}$ (see sections 4.2 and 4.6). Here we will provide a brief overview of these records, and the redox constraints they have placed on the evolution of the Earth. This will provide a basic framework for the reader to interpret the newer, and often more controversial, trace metal isotope and proxy records for evolving oxygen levels. We have included these redox considerations for two reasons. First, trace metal isotopes are becoming increasingly used in the field of geochemistry and new datasets are being rapidly generated. Second, and perhaps more important for the purposes of this review, even if the metals themselves do not have a direct biological role (i.e., Cr as opposed to Mo), they shed light on the production and trajectory of oxygen in 
the water column. The latter is fundamentally tied to the activity and evolution of the biosphere. As such, we feel it imperative to discuss the trace element records in IF and black shale, in light of the associated chemical context that controls ambient redox potential.

\subsubsection{Sulfur mass-independent fractionations}

The disappearance of S-MIF is perhaps the most accepted evidence for the onset of widespread and permanent oxygenation of the Earth's surface to levels above $10^{-5}$ times present atmospheric levels (PAL) (see Pavlov and Kasting, 2002; Bekker et al., 2004; Farquhar et al., 2000; 2011). Below this threshold, photolytic reactions between ultraviolet rays and sulfur gases in the atmosphere produce isotopic anomalies that deviate from mass dependent behavior and are subsequently recorded in marine sedimentary rocks. However, once oxygenic photosynthesis leads to an accumulation of

appreciable oxygen, above $10^{-5} \mathrm{PAL}$, this allows an ozone layer to form, shielding the Earth from harmful UV rays and suppressing S-MIF. Although modeling has suggested that the S-MIF signal may be carried forward for 10-100 Ma through sedimentary recycling (Reinhard et al., 2013a), it remains a definitive marker for the first major rise in atmospheric oxygen and a fundamental change in the redox state of the Earth.

\subsection{Iron speciation}

Iron speciation, a technique developed by Berner, Canfield, and colleagues (e.g., Berner, 1970; Canfield, 1989) and refined by Poulton and Canfield (2005) for application to ancient sediments, has offered many new insights into the evolving redox state of the 
early Earth. Iron speciation is predicated on determining the amount of Fe in a given sample that has been partitioned into various phases - carbonates, ferric oxyhydroxides, magnetite, and sulfide - relative to the total amount in a sample; see Poulton and Canfield (2011) for a brief review. The ratio of Fe in highly reactive phases (the sum of the four aforementioned phases) to total Fe effectively diagnoses sediment deposition from anoxic water column settings. Combining this further with the ratio of pyrite extractable Fe to highly reactive Fe allows samples deemed anoxic to be further categorized as ferruginous or euxinic. Fe speciation analyses have shed new light on the spatial complexity of water column redoxclines (e.g., Poulton et al., 2010), and have shown that the Proterozoic was likely dominated by ferruginous conditions (Planavksy et al., 2011; Poulton and Canfield, 2011). Poulton and Canfield (2011) highlight several fundamental shifts based on a number of Fe-speciation analyses. They suggest that the oceans were dominantly ferruginous until the late Archean after which a surface oxic layer likely formed. During the Paleoproterozoic to Neoproterozoic, this surface oxic layer probably persisted, but with a euxinic wedge on the shelf with underlying ferruginous waters (Li et al., 2010). A recent assessment of a compilation of Fe speciation data suggests that bottom waters may have remained ferruginous well into the Paleozoic (Sperling et al., 2015).

\subsection{Proxy records for trace element evolution}

\subsubsection{Iron formations}

Iron formations (IF) are iron-rich (15-40 wt \%) and siliceous (40-60 wt \%) sedimentary deposits that precipitated from seawater throughout much of the Archean and Paleoproterozoic (3.75-1.85 Ga) (James, 1954; Trendall, 2002; Klein, 2005). Deposition 
of IF appears tied to periods of enhanced magmatic and hydrothermal activity (associated with large igneous province emplacement; Isley and Abbot, 1999) that delivered large amounts of ferrous iron to anoxic deep oceans (Bekker et al., 2010; 2014). Low concentrations of $\mathrm{Al}_{2} \mathrm{O}_{3}(<1 \mathrm{wt} \%)$ and incompatible elements ( $\mathrm{Ti}, \mathrm{Zr}$, Th, Hf and $\mathrm{Sc}<20$ ppm) are commonly observed in IF, indicating minimal detrital input during deposition, although this is not universal for all iron formations.

Iron formations may be divided into two petrographic affinities: banded iron formation (BIF) and granular iron formation (GIF). BIF are characterized by distinctive layering of variable thickness, from macrobands (meters in thickness), to the more characteristic mesobands (centimeter-thick units) from which they draw their name, to millimeter and submillimeter microbands (e.g., Trendall and Blockley, 1970; Morris, 1993; Krapež et al., 2003). GIF typically lack banding and consist of granules of chert or other silicates and iron oxides with early diagenetic chert cement filling pore spaces (e.g., Simonson, 1985). BIF dominate the Archean and are more important in terms of total IF tonnage (Bekker et al., 2010). GIF first appear in the rock record at ca. $2.4 \mathrm{Ga}$ (Simonson and Goode, 1989) and are the most common type of iron formation in the Paleoproterozoic, reaching their peak abundance ca. $1.88 \mathrm{Ga}$. After a $1.88 \mathrm{Ga}$ pulse of IF deposition, which appears to have been globally synchronous (Rasmussen et al., 2012), they effectively disappear in the middle Proterozoic, returning in the Neoproterozoic in association with widespread "Snowball Earth" glaciation (Hoffman et al., 1998). While the Phanerozoic is devoid of the IF resembling those of the Precambrian, the iron oxiderich sedimentary record is continued into the Phanerozoic in the form of ironstones (see 
Mücke and Farshad, 2005 for review) and exhalative deposits (see Lyons et al., 2006 for review).

Iron formation deposition spans several major redox changes in Earth's surface composition-from an early anoxic atmosphere to an atmosphere that became at least partially oxygenated (e.g., Klein, 2005; Bekker et al., 2010). Therefore, it is likely that IF formed via different mechanisms throughout the Precambrian. A number of recent reviews detail IF occurrence, mineralogy, mechanisms of formation, depositional environments, and diagenetic history (see Klein, 2005; Bekker et al., 2010, 2014; Posth et al., 2014). For the purpose of this review, the importance of IF is its ability to record marine signatures, and specifically archive trace element concentrations in the Precambrian.

Evidence supporting the idea that IFs record authigenic marine signatures includes marine-like rare earth element and yttrium (REE+Y) patterns and small-scale chemical variations that argue for the preservation of environmental signals (e.g., Bau and Möller, 1993; Bau and Dulski, 1996; Bolhar et al., 2004; Alexander et al., 2008; Pecoits et al., 2009; Planavsky et al., 2010a; Haugaard et al., 2013, 2016). A concern potentially compromising the IF record is the possibility of post-depositional mobilization of trace elements, which can overprint or even eradicate authigenic marine signatures. However, limited post-depositional mobilization or addition of trace elements in IF is indicated by small-scale REE and Fe isotope variations, both within and between Fe-rich mesobands despite experiencing diagenetic and metamorphic conditions up to amphibolite facies (e.g., Bau, 1993; Frost et al., 2007; Whitehouse and Fedo, 2007; Steinhoefel et al., 2010). Trace element compilation efforts for IF have often limited their 
scope to samples falling at greenschist facies or below in an effort to provide the most robust estimates possible of trace element abundances.

Recently, the use of IF as paleomarine proxies for trace element abundances has been questioned because laboratory studies of Fe(II)-redox driven recrystallization suggest that this process may overprint authigenic trace element records (Frierdrich et al., 2011; Frierdich and Catalano, 2012). These studies focused largely on the initial sorption of trace metals and subsequent remobilization that occurs upon further interaction with Fe(II)-rich fluids. They also specifically highlighted the potential for the mobilization of Ni (Frierdich et al., 2011) and Zn (Frierdich and Catalano, 2012). Generally, losses were less than $10 \%$ when ferrihydrite doped with $\mathrm{Ni}$ or $\mathrm{Zn}$ was placed in a $\mathrm{Fe}(\mathrm{II})$ solution that contained no Ni or Zn. However, further experimental work (Frierdich et al., 2012) has shown that when impurities of $\mathrm{Al}, \mathrm{Cr}$, or $\mathrm{Sn}$ are present in the ferrihydrite, $\mathrm{Ni}$ and $\mathrm{Zn}$ remobilization is attenuated. Such a scenario is likely more comparable to natural iron oxyhydroxides formed in the Precambrian oceans that were the precursors to the minerals presently found in IFs, as they would have incorporated various trace metals and other minor impurities from the water column. Ultimately, the studies of Frierdich et al. (2011) and Frierdich and Catalano (2012) are based on systems inherently at disequilibrium and that are unlikely to be truly representative of the formation of IF particles in equilibrium with contemporaneous ferruginous seawater. Further, none of these studies have assessed the potential for the mobility of trace elements during later diagenetic mineral phase transitions. In this regard, recent experimental work using diagenetic capsule experiments (Robbins et al., 2015) demonstrated limited mobility for $\mathrm{Ni}$ and $\mathrm{Zn}$ during simulated diagenetic treatments at high temperature and pressure that capture the transformation 
from ferrihydrite to hematite. Overall, when all lines of evidence are considered, it is reasonable to conclude that IF do indeed preserve authigenic signatures and thus record the abundances of biologically critical trace elements in ancient oceans with high fidelity.

Recent attempts to connect the record of trace metals in IF to coeval trace element abundances in seawater may be hampered by the empirical sorption models (e.g., linear partitioning, or $\mathrm{K}_{\mathrm{D}}$, models) typically employed to determine metal partitioning between seawater, microbes, mineral colloids, and organic ligands in the water column. These partitioning models are only applicable at the experimental conditions tested and say nothing about the chemical mechanisms of trace metal uptake (Sposito, 1982; Goldberg and Criscenti, 2007). Erel and Stolper (1993), improving on earlier $K_{D}$ studies such as those of Byrne and Kim (1990) and Koeppenkastrop and De Carlo (1992), proposed a semi-empirical model that linked the binding of marine REE to microbes and particulate matter to their first hydroxide thermodynamic binding constants (e.g., constants for hydrous ferric oxides found in Dzombak and Morel, 1990). Aqueous REE concentrations were successfully modeled by employing REE-carbonate complexation mass action constants. While admitting that their model could not account for factors including $\mathrm{pH}$ and binding site concentrations, Erel and Stolper (1993) found that the model was able to predict REE concentrations in modern seawater and approximate REE patterns observed in Archean BIF.

More recently the surface complexation modeling (SCM) approach, grounded in equilibrium thermodynamics through mass action expressions, has been extended beyond minerals to successfully model trace metal adsorption onto microbial surfaces (Fein et al., 1997, 2005), including marine cyanobacteria (Liu et al., 2015) and anoxygenic 
photosynthesizers (Martinez et al., 2016). Although data-intensive, the SCM approach allows us to predict the impacts of the aqueous speciation of metals, redox transitions, $\mathrm{pH}$, the precipitation and dissolution of solid phases, competition of multiple metals for specific types of surface binding sites, varying metal-to-sorbent ratios, and ionic strength on the final distribution of trace metals in a system (Davis et al., 1998; Koretsky, 2000)without conducting additional experiments. For example, SCM studies allow for systematic investigation of the impacts of paleoseawater salinity (Sanford et al., 2013), pH (Pearson and Palmer, 1999; Ohnemueller et al., 2014) and competition on the uptake of trace metals to particles in the photic zone, for instance, Fe-Mn-oxyhydroxides and planktonic microbes. Binding constants from disparate studies in the literature could be combined, unlike in empirical approaches such as the $\mathrm{K}_{\mathrm{D}}$ model. Ultimately, the further application of SCM promises to better connect paleoseawater geochemistry and microbiology to trace metals trends observed in the rock record.

A final limitation on the use of the IF record is the lack of direct modern analogues. However, several studies have used Phanerozoic ironstones and hydrothermal exhalites to extend the record from the Precambrian to the modern (e.g., Konhauser et al., 2009; 2011; 2015; Partin et al., 2013a; Robbins et al., 2013; Swanner et al., 2014). Such hydrothermal deposits provide an opportunity to test experimental and hypothesized partitioning scenarios for trace elements onto IF-but only to a limited extent. As these partitioning scenarios are sensitive to matrix effects, such as different Si concentrations (e.g., Konhauser et al. $(2007,2009)$ and the presence of additional cations, (Jones et al. (2015), see also section 4.1), they cannot be directly equated. Although the $K_{D}$ value for $\mathrm{P}$ adsorbing to $\mathrm{Fe}$ in modern hydrothermal particles (Bjerrum and Canfield, 2002) is very 
close to the experimentally-derived value for Si-free seawater developed by Konhauser et al. (2007), further refinement of these partitioning scenarios is needed, and SCM may be a useful tool for future work. Additionally, the broad scaling between trace metals and $\mathrm{Fe}$ in IF suggest that first order partitioning trends are largely preserved (e.g., Robbins et al., 2013; Konhauser et al., 2015). The observed scaling between $\mathrm{Zn}$ and $\mathrm{Fe}$ in modern hydrothermal deposits falls just above that for IF $\mathrm{Zn} / \mathrm{Fe}$ ratios (Robbins et al., 2013). Collectively, these considerations suggest that the use of modern hydrothermal exhalites to extend the IF record is justified.

\subsubsection{Shales}

The shale record is another powerful source of information, especially organic matterrich mudrocks, also known as black shales (with $>0.5 \mathrm{wt} \%$ TOC). Shales are fine-grained sedimentary rocks containing variable amounts of organic matter that are typically deposited in low energy environments and can provide key information regarding local bottom-water redox conditions and the extent of primary paleo-productivity. The latter may be inferred from trace element enrichments that are intimately associated with organic carbon burial fluxes, which are in turn favored under anoxic depositional conditions (e.g., Ni, Cu, Zn, Cd; Tribovillard et al, 2006; Algeo and Rowe, 2012). Local bottom water redox conditions are indicated by enrichments in redox sensitive trace metals. Such trace metals are generally soluble in oxygenated seawater but are removed in anoxic seawater or sediment pore waters though authigenic mineral formation and/or uptake by organic matter (e.g., U, V, Mo, Re, $\mathrm{Cr}$, and $\mathrm{Co}$ ). 
Organic-poor shales deposited from well-oxygenated bottom waters typically have low metal burial rates (with possible exceptions, such as $\mathrm{Mn}$ and $\mathrm{Co}$ ) and thus they have generally muted metal enrichments. By contrast, organic-rich black shales deposited under anoxic and sulfidic pore waters may become enriched in redox-sensitive trace metals, especially Mo (Algeo and Lyons, 2006; März et al., 2008; Scott and Lyons, 2012). It is possible for black shales to form beneath oxygenated bottom waters if sedimentation rates are sufficiently high for organic matter to be buried rapidly and escape oxidation or if productivity rates are sufficiently high (e.g., Sageman et al., 2003). Elevated Re and U enrichments without Mo enrichment in black shales are particularly useful indicators for mild bottom water oxygenation and limited oxygen penetration below the sediment-water interface (Crusius et al., 1996; Morford and Emerson, 1999; Morford et al., 2005; Algeo and Tribovillard, 2009). Deposition from anoxic and nonsulfidic bottom waters can also be inferred from trace metal contents, in particular mild Mo enrichments that indicate dissolved sulfide was confined to sediment pore waters (Scott and Lyons, 2012).

The utility of black shales as paleomarine proxies has grown in recent years. In addition to trace metal contents, sedimentary $\mathrm{Fe}$ speciation analysis (Poulton and Canfield, 2005) serves as an indicator of local paleoredox conditions on the ocean floor (i.e., oxic; anoxic, ferruginous; or euxinic) (e.g., Poulton et al., 2004; Canfield et al., 2007; 2008; Lyons et al., 2009; Reinhard et al., 2009; Poulton et al., 2010; Planavsky et al., 2011; Asael et al., 2013). The trace element concentrations of anoxic and euxinic black shales have been used to track corresponding elemental concentrations in the oceans through time (e.g., Scott et al., 2008; 2013; Partin et al., 2013b; Reinhard et al., 
2013b). If black shales can independently be determined to have been deposited under specific redox conditions (by Fe speciation), the degree of metal enrichment (Mo, U, Re, $\mathrm{V}, \mathrm{Cr}$ ) can then be used to track first order shifts in metal concentrations and the global marine redox state (Emerson and Huested, 1991; Lyons et al., 2009). This idea builds from two key principles (explored below): (1) the dominant marine redox condition is the primary control on the size of the dissolved ocean inventory of redox sensitive elements (Emerson and Huested, 1991) and (2) the marine metal reservoir exerts a first order control on enrichments in euxinic and anoxic sediments (Algeo and Lyons, 2006; Lyons et al., 2009; Scott et al., 2008; Reinhard et al., 2013b).

Trace element enrichments in the organic-rich sediments of modern anoxic basins provide the foundation for interpreting ancient seawater metal inventories from organicrich black shales. Algeo and Lyons (2006) showed that the dissolved Mo concentration in euxinic bottom waters is proportional to the observed Mo/TOC ratios in the underlying organic-rich sediments. A similar relationship was demonstrated for Zn (Scott et al., 2013) and likely exists for most trace metals (e.g., Large et al., 2014). Such observations were derived by comparison of data from modern anoxic basins with various degrees of water mass restriction from the open ocean. Isolated anoxic basins typically have lower dissolved metal concentrations because of slow recharge of trace metals from ocean circulation, and a largely anoxic ocean would similarly be expected to have low concentrations due to widespread trace metal draw down (Emerson and Huested, 1991). A temporal compilation of metal enrichments from black shales deposited in sedimentary basins with relatively unrestricted connection to the open ocean should therefore reveal the evolution of seawater metal reservoirs through time. 
For some trace elements, the black shale record provides valuable independent information about the evolution of seawater trace element reservoirs, such as $\mathrm{Zn}$, complementing the IF record (c.f. Scott et al., 2013 and Robbins et al., 2013). A significant advantage of the black shale record over the IF archives is that examples from modern settings, such as the Cariaco Basin and the Black Sea (e.g., Lyons and Berner, 1992; Lyons et al., 2003; Algeo and Lyons, 2006; Scott et al., 2008; 2013; Reinhard et al., 2013b), can be used as analogues to understand the processes underpinning the formation and the pathways of trace metal uptake for their ancient counterparts. Furthermore, the distribution of black shales in the rock record is more continuous compared to IFs and ironstones, whose deposition was limited to certain periods of the geologic record.

One of the additional advantages of black shales is that they have low permeability, which contributes to the retention of primary depositional signatures despite the potential for metals to be remobilized during diagenetic processes. While the possibility for diagenetic mobilization does exist, several lines of geochemical evidence can be used to indicate a primary depositional signature. For instance, Tribovillard et al. (2006) indicated that unless black shales are exposed to an influx of oxidizing agents after deposition, a number of trace elements commonly associated with sulfides should remain relatively immobile during diagenesis; these include $\mathrm{Mo}, \mathrm{Zn}, \mathrm{Ni}$, and $\mathrm{Co}$, amongst others. Further, the Re-Os radioactive isotope system can provide precise and accurate depositional ages for black shales and, at the same time, confirm that redox-sensitive trace elements have not been significantly affected by post-depositional processes (e.g., Kendall et al., 2009). 


\subsubsection{Sedimentary to early diagenetic pyrite}

The sedimentary pyrite record can also prove useful for tracking trace element abundances. Pyrite $\left(\mathrm{FeS}_{2}\right)$ can form in sediments contemporaneous with deposition or during early diagenesis, and it may therefore incorporate trace element signatures characteristic of seawater (see Large et al., 2014). Focusing on in situ analysis of pyrite grains from black shales, Large et al. (2014) documented the temporal variability of several trace elements, including Mo, $\mathrm{Co}, \mathrm{Ni}$, As, and Se, through geological time. Those authors suggested that in the same way that hydrothermal pyrite can track the chemistry of ore-forming fluids (Large et al., 2009), syngenetic to early diagenetic pyrite can track changes in seawater composition. Large et al. (2014) also provided an assessment of the importance of pyrite versus matrix trace element incorporation, sulfide recrystallization, and the location in the water column or sediment where pyrite forms, which suggest the record is favorable to recording seawater signatures; a result further supported by several additional studies (Gregory et al., 2014; Large et al., 2015; Mukherjee and Large, 2016). Indeed, pyrite framboids formed in the water column may prove to be most useful, but this possibility remains to be tested further. The use of the pyrite records has recently found support in the work of Gallagher et al. (2015) who reported a suite of trace element data (Mo, Ni, As, Co, Zn) from Precambrian to Ordovician carbonate-hosted pyrite deposited in shallow marine environments. Their data were centered on the ArcheanProterozoic and Proterozoic-Phanerozoic transitions and were largely consistent with previous assertions from the shale-hosted pyrite, IF, and black shale records. 
Large et al. (2015) have also used laser ablation analysis of sedimentary pyrite in shales to identify cyclical variations in several key trace elements, including Mo, Se, and $\mathrm{Cd}$, in the late Precambrian through the Phanerozoic. The cyclical pattern in trace element abundances are ascribed to changes in continental uplift and weathering fluxes, and it appears that mass extinction events seem to coincide with periods of anoxia and oceanic nutrient depletion. However, such large changes in input fluxes could be compensated for by relatively minor increases in the extent of anoxia, which would have contributed to the extinction (e.g., Sahoo et al., 2012; Reinhard et al., 2013b). As with the black shale and IF records, the greatest value of the pyrite record likely lies in its ability to produce broad first-order trends.

\subsubsection{Carbonates}

Carbonate rocks can also capture and preserve records of ancient marine chemistry. For example, carbonate-associated sulfate (CAS) has been used to study the oxygenation of the early Earth by tracking seawater sulfate levels and their isotopic properties (e.g., Kah et al., 2004; Gellatly and Lyons, 2005; Gill et al., 2007; Guo et al., 2009; Gill et al., 2011; Planavsky et al., 2012; Guilbaud et al., 2015). In terms of redox sensitive trace elements, a recent study has examined $\mathrm{I} /(\mathrm{Ca}+\mathrm{Mg}$ ) ratios (Hardisty et al., 2014) in order to track surface oxidation of the ocean. The authors showed evidence for an increase in iodate, the oxidized version of iodine, following the GOE and attribute this to the development of an aerobic iodine cycle.

In general, the most important hurdle for any carbonate-specific redox proxy is a thorough understanding of the behavior of the proxy during marine, meteoric, and burial 
diagenesis. These processes can alter carbonate $\delta^{13} \mathrm{C}$ and $\delta^{18} \mathrm{O}$, as well as the trace element compositions (e.g., Schrag et al., 2013; Swart and Kennedy, 2012), limiting their use for paleoenvironmental proxies. For instance, CAS concentrations have been shown to decrease by orders of magnitude during meteoric aragonite-to-calcite alteration, but $\delta^{34}$ S CAS values are preserved during the same process (Gill et al., 2008). A similar study found that seawater $\delta^{34} \mathrm{~S}$ is also preserved even after extensive authigenic carbonate precipitation in pore waters with active sulfate reduction (Lyons et al., 2004), again indicating that original marine isotope ratios are retained through this process.

\subsubsection{Chert as a possible trace element archive}

To date IF and black shales have been the dominant rock types, with sedimentary pyrite being increasingly used to infer evolution of paleomarine trace element reservoirs and redox conditions. A further potential archive that has yet to receive much attention is the Precambrian chert record, with Baldwin et al. (2011) recently discussing the potential for Precambrian cherts to record paleomarine signatures. Abiogenic cherts are predominantly formed in the Precambrian due to high marine silica concentrations in the absence of a biological sink (Siever, 1992; Maliva et al., 2005). Several mechanisms have been proposed for the primary formation of abiogenic Precambrian cherts, including direct precipitation of amorphous silica from seawater (Siever, 1992; Maliva et al., 2005) and more recently sedimentation of sand-sized silica granules (Stefurak et al., 2014; 2015). Thus far, Precambrian cherts have mainly been used to examine paleomarine temperatures from their oxygen and silicon isotope compositions (e.g., Knauth and Lowe, 2003; Knauth, 2005; Robert and Chaussidon, 2006; Marin-Carbonne et al., 2014). 
However, questions remain as to whether these are truly primary marine signals. MarinCarbonne et al. (2014) outlined a set of criteria, both petrographic and geochemical, that can be used to help identify pristine sedimentary cherts. Trace element abundances themselves may also help resolve primary versus secondary signals preserved in cherts (Baldwin et al. 2011; Marin-Carbonne et al., 2014). If appropriate samples are identified, the trace element record in cherts could be a powerful complement, both spatially and temporally, to existing trace element datasets.

\section{Bioessential trace elements, their records, and implications for changes in seawater chemistry and prevailing redox conditions}

\subsection{Phosphorus}

Phosphorus (P) is key for all life and fills a variety of biological roles, including the formation of phospholipids, cellular membranes, and nucleic acids. Due to strong biological scavenging and sorption to $\mathrm{Fe}$ oxyhydroxides, $\mathrm{P}$ is typically present at fairly low concentrations in seawater (0.001-3.5 $\mu \mathrm{M}$; Bruland and Lohan (2003)). In modern oceans $\mathrm{P}$ shows a strong nutrient-type profile, and can often be found below the average marine concentration of $\sim 2.3 \mu \mathrm{M}$ in surface waters (Bruland, 1980; Bruland and Lohan, 2003).

Phosphorus is typically considered to be the limiting nutrient for marine productivity on geologic time scales (Tyrell, 1999). Based on P/Fe ratios in IF (Fig. 4), Bjerrum and Canfield (2002) suggested that prior to $1.9 \mathrm{Ga}$, P sorption to precipitating iron oxyhydroxides would have drawn down the marine P reservoir to levels of around 0.15 to $0.6 \mu \mathrm{M}$, thus limiting primary productivity in the surface oceans. Those authors 
argued that IF acted as a major sink for P, and consequently, their deposition resulted in a $\mathrm{P}$ crisis. Their argument has its roots in the observed drawdown of $\mathrm{P}$ by Fe precipitates near modern hydrothermal vents and the fact that the IF record is characterized by $\mathrm{P} / \mathrm{Fe}$ ratios significantly lower than those observed in iron-rich plume particles today (e.g., Feely et al., 1991; 1998).

However, silica concentrations in the Precambrian oceans were likely much higher (up to $2.2 \mathrm{mM}$, effectively saturated with respect to amorphous silica; c.f. Siever, 1992; Maliva et al., 2005) than in modern oceans (up to $\sim 0.1 \mathrm{mM}$; Bruland and Lohan, 2003). The presence of aqueous silica can greatly affect the partitioning of $\mathrm{P}$ onto $\mathrm{Fe}$ oxyhydroxides. Konhauser et al. (2007) demonstrated that a high silica ocean would have attenuated phosphate adsorption to precipitating Fe oxyhydroxides, thereby keeping $\mathrm{P}$ in solution while still accounting for low $\mathrm{P} / \mathrm{Fe}$ ratios in IF (Fig. 4) —and casting doubt on the idea of an Archean P crisis. Subsequently, Planavsky et al. (2010b) combined the partitioning coefficients derived by Konhauser et al. (2007) with $\mathrm{P} / \mathrm{Fe}$ ratios in the IF record and suggested that $\mathrm{P}$ levels in the Precambrian oceans were at least similar to modern seawater, and perhaps even higher, although this remains debated. Furthermore, they identified a large influx of $\mathrm{P}$ into the oceans coincident with the end of global Neoproterozoic glaciations. More recently, it has been argued that the Neoproterozoic influx of $\mathrm{P}$ to the oceans may instead be directly attributed to the weathering of large igneous provinces (LIPs) (Horton, 2015). This idea is based on compiled P concentrations in LIPs and average mid-ocean ridge basalts, as well as the emplacement of several LIPs that occurred just prior to Neoproterozoic global glaciations and the NOE. 
It should be pointed out, however, that there is renewed debate on the partitioning of $\mathrm{P}$ in the early oceans and its implications for the early biosphere. For instance, Jones et al. (2015) suggested that divalent cations, such as $\mathrm{Ca}^{2+}$ and $\mathrm{Mg}^{2+}$, may also play a strong role in governing the partitioning of $\mathrm{P}$ in ancient silica-rich oceans, renewing the possibility of an Archean, and possibly Proterozoic phosphate crisis. By contrast, it has been suggested that if the ferrihydrite precipitates were not a major flux of sedimenting trace elements, perhaps it was the biomass itself that contributed (via intracellular assimilation) to the P inventory of BIF (Li et al., 2011).

Reconstructing the ancient $\mathrm{P}$ biogeochemical cycle from the shale record is generally restricted to the Phanerozoic. For instance, März et al. (2008) investigated the P and redox sensitive metal content of a Cretaceous black shale interval from the ca. $86 \mathrm{Ma}$ old Coniacian-Santonian ocean anoxic event (OAE). These authors found that $\mathrm{P}$ concentrations were relatively low during deposition from euxinic waters, unlike redox sensitive trace metals, such as $\mathrm{Zn}, \mathrm{V}$, or $\mathrm{Cd}$. By contrast, high $\mathrm{P}$ concentrations were found in black shales deposited from anoxic and non-sulfidic waters where P burial was coupled to Fe oxyhydroxide formation. This strong coupling of $\mathrm{P}$ and Fe during burial suggests that the black shale record in deep time can be used to distinguish anoxic/nonsulfidic versus euxinic deposition. This relationship offers the potential to shed light not only on paleomarine $\mathrm{P}$ abundances but could also in resolving the ongoing debate regarding the interpretation of $\mathrm{P} / \mathrm{Fe}$ ratios in IF. Additionally, Large et al. (2015) measured P in a suite of fifty Phanerozoic black shales and found a cyclical variation in P that seemed to coincide with changes in other trace elements, including Se and Mo. Large et al. (2015) further correlated these nutrient peaks to periods of rapid evolutionary 
change, such as the Cambrian explosion and the rise of tetrapods, whereas periods of nutrient depletion in the Phanerozoic record seem to coincide with mass extinctions. Overall, the Phanerozoic shale studies of P highlight the potential power of the black shale record in elucidating temporal trends in P availability.

\subsection{Molybdenum}

Molybdenum (Mo) is important in a number of vital enzymes, including nitrogenase (used for nitrogen fixation), nitrate reductase (reduction of nitrate to nitrite), and a eukaryotic enzyme for nitrate assimilation (e.g., Kisker et al., 1997; Williams and Frausto da Silva, 2002). Because dissolved Mo is efficiently removed from sulfidic seawater, it was suggested that $\mathrm{Mo}$, amongst other elements (e.g., $\mathrm{Fe}, \mathrm{Cu}$ ), would have been biolimiting in the Proterozoic (Javaux et al., 2001; Anbar and Knoll, 2002) if the seafloor was covered by euxinic waters, as originally hypothesized by Canfield (1998). The authors referred to this relationship as a 'bio-inorganic bridge' through which the geochemistry of the early oceans is linked to the evolution of the biosphere. Molybdenum was considered by those authors to be the best example of how a 'bio-inorganic bridge' could be reflected in the sedimentary record and was the first of many metals examined from this perspective (Scott et al., 2008).

Molybdenum is sourced to the oceans primarily though oxidative weathering of the continents. Under oxic conditions Mo is largely conservative, and in modern oceans it is the most abundant transition metal in seawater ( $\sim 105 \mathrm{nM}$; Collier, 1985). However, in the presence of abundant $\left(10^{-3}-10^{-4} \mathrm{M}\right)$ free hydrogen sulfide, Mo is converted to a series of particle-reactive thiomolybdates and is efficiently removed from seawater (the so- 
called Mo "geochemical switch"; Helz et al., 1996). On a global scale, most Mo is removed to anoxic sediments where sulfide is restricted to the pore waters. However, the rate of Mo burial is an order of magnitude higher under euxinic conditions where hydrogen sulfide is present in the bottom water column. Algeo and Lyons (2006) demonstrated that the Mo/TOC ratio of sediments in modern euxinic settings is positively correlated with the concentration of dissolved Mo in the water column, which scales with local controls and/or the global extent of euxinia. For these reasons, the concentration of Mo in sediments deposited under well-constrained water column redox conditions can be used to track the oxygenation of the oceans through time. For instance, following the GOE, when the Mo weathering flux is assumed to have been robust, concentrations of Mo in euxinic sediments can provide a useful constraint on the spatial extent of ocean euxinia on a global scale, with higher euxinic sediment Mo concentrations expected in oceans that were otherwise well-oxygenated and Mo replete (e.g., Scott et al., 2008; Dahl et al., 2010; Scott and Lyons, 2012; Kendall et al., 2015a).

Scott et al. (2008) identified two distinct first-order increases in the Mo concentrations of black shales related to stepwise increases in atmospheric oxygenation. The first is a diffuse boundary at $\sim 2 \mathrm{Ga}$ that corresponds to an initial rise in Mo/TOC ratios following the GOE. This likely resulted from an increased riverine Mo flux coupled to surface ocean oxygenation, but with subsequently suppressed enrichments related to widespread euxinia (Fig. 5). The second, sharper boundary at $\sim 551 \mathrm{Ma}$ is coincident with increased ocean oxygenation in the late Neoproterozoic. A temporal trend roughly similar to that of the black shale record (Fig. 5) was also observed in a compilation of Mo concentrations in synsedimentary to early diagenetic pyrite through 
time (Large et al., 2014). In the pyrite record, Large et al. (2014; 2015) identify the Mo increase in the Neoproterozoic at $\sim 660 \mathrm{Ma}$. This boundary has since been pushed back to ca. 800 Ma following the discovery of high Mo concentrations in earlier Neoproterozoic black shales (Sahoo et al., 2012; 2016; Chen et al., 2015; Thomson et al., 2015). However, this earlier pulse in Mo appears to be transient, with Mo enrichments showing a systematic stratigraphic drop (Sahoo et al., 2016).

Scott et al. (2008) suggested that the abundance of Mo and Mo/TOC ratios in Proterozoic black shales are consistent with a paleomarine Mo reservoir that was only 10$20 \%$ of the modern ocean. Such a reduced reservoir is close to concentrations that are biolimiting for nitrogen-fixing cyanobacteria ( $\sim 5 \%$ of modern seawater; Zerkle et al., 2006). Importantly, Scott et al. (2008) pointed out that the lower Mo levels indicated for the Proterozoic did not necessarily require widespread euxinic conditions. Expansion of less Mo-reactive, non-euxinic sediments (where sulfide is present but restricted to the pore waters; Scott and Lyons, 2012) to just 10\% of the seafloor could accomplish the observed drawdown. Recent work emphasizing an updated mass-balance model for the Mo geochemical cycle coupled with other geochemical data (e.g., sedimentary $\mathrm{Fe}$ speciation; Cr concentrations) point to a redox-stratified Proterozoic ocean with a greater extent of water column euxinia (up to $1-10 \%$ of the seafloor) compared to today-but also containing a wide expanse of anoxic and ferruginous deep waters where Mo burial rates were likely lower than those under euxinic conditions (Planavsky et al., 2011; Reinhard et al., 2013b). This scenario explains the moderate size of the Proterozoic ocean Mo reservoir without the need for widespread euxinic conditions. Interestingly, Mo limitation of primary productivity prior to the Neoproterozoic may have minimized the 
extent of euxinia in the early ocean because a large pool of organic carbon (itself related to primary productivity) is essential for exhausting the available pool of oxidants and enabling the establishment and maintenance of euxinic conditions (Scott et al., 2008).

Molybdenum (Fig. 5) has also been used to track early stages of photosynthetic $\mathrm{O}_{2}$ production since its primary source to the oceans is through oxidative weathering of the continents (Siebert et al., 2005; Anbar et al., 2007; Wille et al., 2007; Kendall et al., 2010). Following river transport of Mo to the oceans, Mo accumulates in surface waters if they have been mildly oxygenated. In deeper anoxic waters, Mo reacts with sulfide to form oxythiomolybdate complexes (e.g., $\mathrm{MoO}_{4-\mathrm{x}} \mathrm{S}_{\mathrm{x}}{ }^{2-}$ ), which are scavenged from solution by organic matter and sulfide minerals (Erickson and Helz, 2000; Algeo and Lyons, 2006; Helz et al., 2011; Chappaz et al., 2014). Therefore, the availability of Mo in Archean black shales, similar to rhenium (Re), can be used as evidence for mild surface ocean oxygenation and possibly brief "whiffs" of atmospheric oxygen (Anbar et al., 2007). Similar logic was applied to mild Mo enrichments observed in ca. 2.7-2.5 Ga black shales from other sedimentary sections, such as in the Griqualand West Basin, South Africa (Siebert et al., 2005; Wille et al., 2007). An alternative explanation is provided by Lalonde and Konhauser (2015) who suggested that the oxidative weathering responsible for these brief mobilizations of Mo may be due to local oxidation of crustal material by microbial mats on land, a scenario not reliant on atmospheric oxygenation. This remains an area of intense interest and ongoing research.

Kendall et al. (2010) used the coupled geochemical behavior of Mo and Re to show that mild oxygenation, possibly spanning hundreds of meters of the upper water column, occurred on the slope of the 2.6-2.5 Ga Campbell-Malmani carbonate platform. 
This interpretation stems from the similar ease by which Mo and Re are mobilized from the readily oxidized crustal sulfide minerals, yet they exhibit different burial rates when deposited in sediments where oxygen penetration and dissolved sulfide concentrations in pore waters are low (Crusius et al., 1996; Morford and Emerson, 1999; Morford et al., 2005). Such conditions result in authigenic Re enrichment in sediments without Mo because Mo sequestration requires free sulfide, either in the water column or sediment pore waters.

Molybdenum isotopes have also been used to reconstruct the oxygenation of the oceans through time. Duan et al. (2010) used Mo isotope data from the ca. 2.5 Ga Mt. McRae shale to infer that small amounts of oxygen mobilized Mo from crustal sulfide minerals and that some Mo was subsequently adsorbed to oxide mineral surfaces on land or in the surface oceans $\sim 50$ Ma before the GOE. Similarly, Czaja et al. (2012) used coupled Mo and Fe isotope data from 2.68-2.50 Ga carbonates and black shales deposited on the slope of the Campbellrand-Malmani platform to confirm the presence of free dissolved $\mathrm{O}_{2}$ in the water column at the time of deposition. This relationship suggests that Fe oxyhydroxides formed on the Campbellrand-Malmani carbonate platform were likely the result of $\mathrm{Fe}$ (II) oxidation by dissolved $\mathrm{O}_{2}$ rather than by photoferrotrophs, and importantly, that photosynthetic $\mathrm{O}_{2}$ production by cyanobacteria was initiated by $\sim 2.7$ Ga. However, an alternative plausible explanation for the observed isotopic variations of Czaja et al. (2012) is the precipitation of isotopically heavy Fe oxyhydroxides as the result of anoxygenic photosynthesis and carrying isotopically light Mo sorbed to the mineral surface - thereby not definitively indicating the process of oxygenic photosynthesis. 
Recently, Planavsky et al. (2014b) examined the Mo isotope record of Mn-rich IF of the ca. $2.95 \mathrm{Ga}$ Sinqeni Formation, Pongola Supergroup (South Africa) and found evidence for small amounts of oxygen that likely would have existed in the form of a transient oxygen oasis at the ocean's surface (as per Olson et al., 2013). Planavsky et al. (2014b) further argued that the Mo isotope data of the Sinqeni Formation preserves the expression of Mo isotope fractionation during adsorption of Mo to Mn(IV)-oxides in shallow marine settings. The inferred presence of $\mathrm{Mn}(\mathrm{IV})$ oxides requires that free oxygen was available in shallow marine waters because $\mathrm{O}_{2}$ is the only oxidizing agent other than $\mathrm{H}_{2} \mathrm{O}_{2}$ strong enough for oxidation of $\mathrm{Mn}$ (II) to $\mathrm{Mn}(\mathrm{IV})$; however, see Johnson et al. (2013) for an alternative view. Hence, the Mo enrichment and isotope records suggest that oxygenic photosynthesis likely evolved by more than 500 million years prior to the GOE.

Molybdenum isotope data has also been used in conjunction with $\mathrm{U}$ and $\mathrm{Fe}$ isotope data and sedimentary $\mathrm{Fe}$ speciation to demonstrate that a dramatic decline in ocean oxygenation occurred following the GOE (Asael et al., 2013; Partin et al., 2013b). Asael et al. (2013) calculated the seawater Mo isotope composition $\left(\delta^{98} \mathrm{Mo}\right)$ to be $0.85 \pm$ $0.20 \%$, which is significantly lighter than modern seawater $(2.3 \%)$ and thus consistent with an appreciable extent of euxinic waters in the Proterozoic ocean. The interpretation of euxinia was further supported by the iron speciation analysis conducted on their samples. A similar conclusion was drawn for the late Paleoproterozoic and early Mesoproterozoic ocean based on sedimentary Fe speciation and Mo concentration and isotope data from the ca. 1.8 Ga Rove Formation (Canada) and ca. 1.4 Ga Velkerri Formation (Australia) (Arnold et al., 2004; Kendall et al., 2009; 2011). Similar Mo 
isotope signatures for expanded ocean euxinia have also been documented from Neoproterozoic black shales, including the $\sim 750$ Ma Walcott Member of the Chuar Group, Grand Canyon (Dahl et al., 2011) and the ca. 640 Ma Black River Dolomite (Kendall et al., 2015a). It is not until ca. 560 Ma that seawater Mo isotope compositions similar to modern seawater are first inferred from the sedimentary rock record (see Sahoo et al., 2016).

A recent compilation of Mo isotope data for euxinic black shales also reveals that significant oscillations in ocean redox conditions, and hence the seawater Mo inventory, may have occurred across the Precambrian-Phanerozoic transition before the advent of permanent widespread ocean oxygenation (Dahl et al., 2010; Kendall et al., 2015a; Sahoo et al., 2016). This view adds a new dimension to existing evidence for predominantly ferruginous deep ocean conditions in the Proterozoic (e.g. Canfield et al., 2007; 2008; Poulton et al., 2010; Poulton and Canfield, 2011; Johnston et al., 2010; Planavsky et al. 2011; Reinhard et al., 2013b; Li et al., 2015; Guilbaud et al., 2015), whereby transient ocean oxygenation events (OOEs) may have punctuated periods of relative redox stasis (Sahoo et al., 2016). However, some caution must be exercised when viewing the Mo isotope record in black shales as a consistent tracer of seawater signatures. This is due to variability observed in the modern sediments of the euxinic Black Sea, where Mo isotope fractionations vary as a function of sulfide concentration (Neubert et al., 2008). Essentially, in order to record a seawater signature, a critical level of at least $11 \mu \mathrm{mol} \mathrm{L} \mathrm{L}^{-1}$ $\mathrm{H}_{2} \mathrm{~S}_{(\mathrm{aq})}$ is required. Under more weakly euxinic conditions, Mo removal may not be quantitative, which can result in variable isotopic fractionation between the sediment and overlying water column. This isotopic fractionation is due, at least in part, to the 
fractionation of Mo isotopes amongst various aqueous species (Tossell, 2005), and accordingly a critical amount of sulfide is required to ensure that all Mo is in the tetrathiomolybdate phase and that Mo is quantitatively scavenged. Under such a scenario, the Mo isotope composition of sediment deposited under non- to weakly-euxinic conditions would depart from that of the source (i.e., contemporaneous seawater), thereby affecting the ability of euxinic sediments to track the Mo isotope composition of the early oceans. Accordingly, in order to track the Mo isotope composition of the early oceans, black shales need to be deposited under conditions with persistent and appreciable levels of dissolved sulfide (Neubert et al., 2008; Gordon et al., 2009; Arnold et al., 2012).

The paleomarine Mo record (Fig. 5) also has important implications for biological evolution in the Neoproterozoic. In line with related suggestions by Anbar and Knoll (2002), Boyd et al. (2011) suggested that the emergence of Mo-Fe nitrogenases appears to correlate with, at least transiently, increasing seawater Mo concentrations around the GOE. However, this timing has recently been challenged on geochemical evidence. Stüeken et al. (2015a) report a suite of fluvial to marine sedimentary rocks at 3.2 Ga that have an average nitrogen isotopic composition $\left(\delta^{15} \mathrm{~N}\right)$ of $0.0 \pm 1.2 \%$. They argue that the only way to record such a signal is through a biological pathway utilizing Mo-nitrogenase and that any abiological pathway of nitrogen fixation or an alternative nitrogenase would inherently impart a substantially different $\mathrm{N}$ isotope fractionation. These studies suggest not only a relatively early origin for Mo-nitrogenase but also have implications for the bioavailability of Mo at very low dissolved concentrations in the Mesoarchean. This would be physiologically consistent with observations of Mo-nitrogenase activity at very low Mo levels in culture studies (Zerkle et al., 2006; Glass et al., 2009). By contrast, 
Sánchez-Baracaldo et al. (2014) used phylogenomic reconstruction to suggest the Cryogenian $(0.85$ to $0.635 \mathrm{Ga})$ as the origin of $\mathrm{N}$-fixing cyanobacteria. However, the history of Mo as recorded by the chemical sedimentary record is more consistent with an early origin for Mo-nitrogenase, or at least its precursor, and a subsequently consistent limitation of N-fixation by a Mo-depleted Proterozoic ocean (i.e., Lyons et al., 2014b).

\subsection{Nickel}

Nickel (Ni) is critical for many prokaryotic metalloenzymes. It is utilized in carbon reduction by both acetogenic and methanogenic bacteria, as well as the cofactors methylcoenzyme M reductase and acetyl-CoA synthase, both of which are critical for methane production (Hausinger, 1987; Zerkle et al., 2005, and references therein). Furthermore, Ni is used in hydrogenases, carbon monoxide dehydrogenase, and catalyzes the reduction of $\mathrm{CO}_{2}$ to $\mathrm{CO}$ and the resultant production of acetyl-CoA (e.g., Ragsdale and Kumar, 1996). In non-methanogens, $\mathrm{Ni}$ may be used in urease and in a recently evolved superoxide dismutase found in many marine organisms (Frausto da Silva and Williams, 2001; Dupont et al., 2008).

Initial estimates of $\mathrm{Ni}$ concentrations in the early ocean were derived from geochemical modeling (Saito et al., 2003) and microbial genomics (Zerkle et al., 2005). These studies suggested that seawater Ni concentrations were fairly uniform from the Archean through to the modern (Fig. 1). The presumed consistency largely stems from $\mathrm{Ni}$ behaving conservatively in waters under various redox conditions (Saito et al., 2003). However, a compilation of $\mathrm{Ni}$ contents in IF through time (Konhauser et al., 2009) revealed a unidirectional and rapid decrease in Ni just prior to the GOE (Fig. 6). This 
trend remained clear after a near-doubling of the available IF data (Konhauser et al., 2015), suggesting that the observed decline in Ni in IF is robust. Using experimentally derived Ni partitioning coefficients to Si-rich ferrihydrite (in light of assumed elevated Precambrian silica concentrations), it was estimated that paleomarine Ni concentrations dropped by more than half between 2.7 and $2.5 \mathrm{Ga}$ (Fig. 6), from close to $400 \mathrm{nM}$ to less than $200 \mathrm{nM}$. This decline would have strongly impacted methanogenic bacteria, since they are highly dependent on dissolved Ni availability over this range. This decline was attributed to mantle cooling and, with that, the decreasing frequency of Ni-rich ultramafic eruptions. This subsequently limited the amount of $\mathrm{Ni}$-source rocks susceptible to weathering, and perhaps even impacted atmospheric oxygenation by its effect on biological carbon cycling (Konhauser et al., 2009; 2015; see Kasting, 2013 for an alternative view).

Eickhoff et al. (2014) re-examined the partitioning of nickel to both biogenic and abiogenic ferrihydrite in the presence of silica. Although estimates from Eickhoff et al. (2014) are not directly comparable to that of Konhauser et al. (2009) due to differences in their respective experimental approaches, they nonetheless found that when biomass was present, the sorption of $\mathrm{Ni}$ onto ferrihydrite decreased, and therefore estimates for the paleomarine Ni concentrations based on IF may be too low. This has led to the suggestion that the collapse of the paleomarine Ni reservoir and the resultant methanogenic famine at 2.7 Ga as described by Konhauser et al. (2009) may have actually occurred closer to the initiation of the GOE shortly before $2.45 \mathrm{Ga}$. Regardless, changes in the paleomarine $\mathrm{Ni}$ reservoir would likely have had profound impacts on the Precambrian biosphere. 
Interestingly, the first-order trends in $\mathrm{Ni}$ abundances observed in the IF record (Fig. 6) are also recorded in sedimentary pyrite. Large et al. (2014) presented a suite of $\mathrm{Ni}$ analyses in sedimentary to early diagenetic pyrite that mirrored the observed temporal trend in $\mathrm{Ni} / \mathrm{Fe}$ ratios observed in IF. Such agreement between two distinct proxy records is encouraging and supports the interpretation that they reflect first-order trends in paleomarine bioavailability. Large et al. (2014) further noted a correlation between Ni and Co in the pyrite record, and suggested that this may be tied to the emplacement and subsequent erosion of large igneous provinces. An observation that supports this assertion is the high Ni and Co values observed in pyrites in the Late Permian (Large et al., 2014), in which case the Ni and Co may be associated with the Siberian traps volcanism and Permian mass extinction (Rothman et al., 2014).

Studies of the Permian mass extinction have also invoked links between the temporal evolution of the paleomarine Ni reservoir and its effects on the methanogenic community in efforts to constrain the cause of this event. An expansion of the marine nickel reservoir, coincident with massive eruptions of the Siberian flood basalts around 252.8 Ma, is suggested to have contributed to the severity of the mass extinction (Rothman et al., 2014). Siberian volcanism would have provided a large transient flux of Ni to the oceans and stimulated methane fluxes to the oceans and atmosphere. Those authors found three different lines of proxy evidence for this expansion: (1) an increase in the size of the marine inorganic carbon reservoir and an isotopic signal suggestive of methanogenic activity, (2) molecular clock analyses indicating the emergence of an efficient acetoclastic methanogenic pathway in Methanosarcina, and (3) significantly elevated Ni concentrations in sediments from South China. All three of these signals 
correlate with the Permian mass extinction and highlight how relatively short-scale perturbations in the bioavailability of trace elements may have potentially affected the biosphere.

Studies in the ferruginous ocean analogue Lake Matano, Indonesia, have shown that green rust may play an important role in scavenging $\mathrm{Ni}$ from ferruginous water columns (Zegeye et al. 2012). Further, production of trace hydrogen sulfide through microbial sulfate reduction may play a strong role in governing aqueous $\mathrm{Ni}$ concentrations, even under ferruginous conditions (Crowe et al. 2008, Zegeye et al. 2012). In Lake Matano, Ni and Co exhibit divergent behavior implying that different biogeochemical process govern concentrations of each metal (Crowe et al. 2008).

\subsection{Zinc}

Zinc ( $\mathrm{Zn})$ is amongst the most biologically important trace metals, particularly for eukaryotes, and is a component in a wide variety of metallo-peptides and polymerases (see Lipscomb and Sträter, 1996 for a review on Zn enzymology). Many Zn metalloenzymes are used in processes involving DNA or RNA synthesis (e.g., Lipscomb and Sträter, 1996; Berg and Shi, 1996). In eukaryotes, $\mathrm{Zn}$ is also used in $\mathrm{Zn}$-fingers, small protein structural motifs which act as signaling agents in processes centralized in the nucleus and are thought to have emerged relatively late (e.g., Berg and Shi, 1996; Dupont et al., 2006, 2010).

Prior to compilations of $\mathrm{Zn}$ data from the sedimentary proxy record, the only estimates for $\mathrm{Zn}$ concentrations and bioavailability came from geochemical modeling (e.g., Saito et al., 2003) (Fig. 1). This modeling work was consistent with the emergence 
of eukaryotic metalloenzymes and rapid diversification of eukaryotes in the Neoproterozoic following a transition from a widely anoxic ocean with expanded euxinia to a well-oxygenated ocean (Dupont et al., 2010). This view provides a possible explanation for the delay in eukaryotic diversification.

Recently, however, two studies have reevaluated paleomarine concentrations through time, and thereby $\mathrm{Zn}$ bioavailability, using the sedimentary rock record. Scott et al. (2013) focused on black shales, building from the observation that $\mathrm{Zn} / \mathrm{Al}$ ratios in sediments from modern euxinic basins are positively correlated with dissolved $\mathrm{Zn}$ concentrations in bottom waters. Scott et al. (2013) found there was no evidence in the Precambrian black shale record to infer a depleted paleomarine Zn reservoir-because the average $\mathrm{Zn}$ concentration in Precambrian and Phanerozoic euxinic shales are not significantly different. Accordingly, they suggested that seawater $\mathrm{Zn}$ levels remained broadly uniform throughout time at near modern levels and several orders of magnitude above concentrations that would be biolimiting. This finding was bolstered by Robbins et al. (2013) who examined $\mathrm{Zn}$ concentrations and $\mathrm{Zn} / \mathrm{Fe}$ ratios in IF (Fig. 7) and found generally constant $\mathrm{Zn}$ enrichments through time. When viewed alongside updated geochemical models for $\mathrm{Zn}$ speciation, and considering hypothesized partitioning scenarios for Zn and Fe co-precipitation, Robbins et al. (2013) estimated a paleomarine $\mathrm{Zn}$ reservoir on the order of $10 \mathrm{nM}$. This value is several orders of magnitude above the $\sim 10^{-13} \mathrm{M}$ concentration considered as biolimiting (Brand et al., 1983) and in excellent agreement with the black shale record (Scott et al., 2013). However, Zn displays nutrienttype behavior in modern seawater, and it is possible that $\mathrm{Zn}$ drawdown also occurred in ancient surface waters; sedimentary proxy records are generally considered to reflect the 
overall size of the paleomarine reservoir without addressing the finer details of its vertical structure.

The updated view of a relatively static paleomarine $\mathrm{Zn}$ reservoir (Fig. 7) contradicts the findings of earlier geochemical models that linked (1) the low $\mathrm{Zn}$ requirements of cyanobacteria to the predicted low levels of total $\mathrm{Zn}$ in the Precambrian oceans, and also (2) the proliferation of eukaryotes to an increase in total $\mathrm{Zn}$ during the Phanerozoic (e.g., Saito et al., 2003; Dupont et al., 2010). This disparity can be linked to an overestimation of the effects of $\mathrm{Zn}$ aqueous complexation by sulfides during the Precambrian by early geochemical models (e.g. Saito et al., 2003). Additionally, this model directly contradicts the behavior of $\mathrm{Zn}$ in some modern anoxic aqueous systems. For instance, in some conditions where a strong redoxcline exists, such as in Jellyfish Lake, Palau, total dissolved $\mathrm{Zn}$ concentrations increase with depth due to the formation of aqueous sulfide complexes (Landing et al., 1991; Dierssen et al., 2001). Alternatively, Robbins et al. (2013) proposed that an increased proportion of hydrothermal fluxes relative to riverine fluxes and the transport of hydrothermal $\mathrm{Fe}$ - and $\mathrm{Zn}$-rich fluids to more distal environments in anoxic Archean and Paleoproterozoic oceans could have helped maintain a large marine $\mathrm{Zn}$ reservoir.

This view of severe Zn limitation (e.g., Saito et al., 2003) was also based the assumption that its availablility for biological use was limited to free dissolved $\mathrm{Zn}^{2+}$. In the modern oceans, the majority of $\mathrm{Zn}$ in surface waters is complexed with organic ligands (90-98\%). This organic ligand pool has traditionally been viewed as being a nonbioavailable component of the total $\mathrm{Zn}$ pool (Bruland, 1989). This framework was based on culture work that has either not applied synthetic ligands to culture or introduced 
EDTA (a strongly binding organic ligand), neither of which are an accurate representative of natural waters. In contrast, it was noted more recently by Lohan et al., (2005) that marine phytoplankton appear to be much more tolerant of low dissolved $\mathrm{Zn}$ concentrations than in culture studies. The authors then went on to propose that $\mathrm{Zn}$ binding organic ligands may be produced by phytoplankton in order to facilitate biological uptake, and to regulate ambient $\mathrm{Zn}$ concentrations. Consistent with this idea is recent culture work after Xu et al. (2012) and Aristilde et al. (2012), where it was demonstrated that weakly binding organic ligands can in fact increase $\mathrm{Zn}$ uptake rates in phytoplankton. This work highlights a gap in our understanding of $\mathrm{Zn}$ forms available for biological use, and complicates predictions on its past bioavailability. As such, debate of Zn bioavailability calls for new methods and data so as to directly test this in future work.

There is also potential for further inferences to be drawn from the stable isotope record of $\mathrm{Zn}$ in chemical sediments, such carbonates. A study on a Neoproterozoic (Marinoan) cap carbonate sequence shows variations in $\delta^{66} \mathrm{Zn}$ that are suggested to record an increase in surface runoff and continental weathering coincident with the onset of deglaciation and a subsequent increase in primary productivity caused by development of nutrient-rich surface waters (Kunzmann et al., 2013). A single study on $\mathrm{Zn}$ isotopes in IF (Pons et al., 2013) found some of the most enriched $\delta^{66} \mathrm{Zn}$ values between $2.7 \mathrm{Ga}$ and 1.8 Ga. Variations were considered to be rapid and governed by two factors: preferential incorporation of isotopically heavy $\mathrm{Zn}$ into carbonates and a significant increase in the amount of marine sediments exposed to weathering around $2.7 \mathrm{Ga}$ coincident as the result of increased continental land mass. These studies highlight the potential of the $\mathrm{Zn}$ stable 
isotope record for understanding links between trace metal in past environments availability and biological productivity, as well as examining source-sink relationships.

\subsection{Cobalt}

The most recognized biochemical role of cobalt (Co) is its participation as a cofactor in cobalamin (vitamin $\mathrm{B}_{12}$ ), which is essential for a number of metalloenzymes, including methionine synthase and ribonucleotide reductase (e.g., Marsh, 1999; Frausto da Silva and Williams, 2001). In previous modeling work, researchers have pointed to the antiquity of the cobalamin cofactor, suggesting that its origin somewhere between 3.5 and 2.7 Ga is consistent with the evolution of cyanobacteria in a Co-rich ocean (Saito et al., 2003). Additional biochemical functions of Co exist (Kobayashi and Shimizu 1999), including in cambialistic carbonic anhydrases enzymes (Morel et al., 1994; Roberts et al., 1997), and perhaps more will be discovered with emerging metalloproteomic techniques (e.g., Waldron et al., 2007; Aguirre et al. 2013). Modeling efforts have indicated that seawater Co concentrations could have been relatively high in the Archean, decreased in the Proterozoic, and then further decreased following Neoproterozoic ocean oxygenation (Saito et al., 2003). Despite the predicted decreases in the seawater concentration of Co over time, the biological utilization of Co is suggested to have increased over time, and remains relatively high (David and Alm, 2011; Swanner et al., 2014). This may be related to the occurrence of Co-binding ligands in Co-limited waters, which exerts strong control over the speciation of Co in the modern ocean (Saito and Moffett, 2001; Saito et al., 2005). Indeed, a high degree of Co complexation may favor cyanobacteria over 
eukaryotic phytoplankton in modern settings containing picomolar levels of dissolved Co, for example in the Costa Rica upwelling dome (Saito et al. 2005; Ahlgren et al., 2014).

An examination of Co concentrations in IF and pyrite through time suggests an expansion of the paleomarine Co reservoir between 2.8 and 1.8 Ga (Swanner et al., 2014). This conclusion is indicated by a large increase in Co/Ti ratios in IF (Fig. 8), euxinic shales, and pyrite relative to the evolving continental crust, with a peak in $\mathrm{Co} / \mathrm{Ti}$ values observed at $\sim 2.4 \mathrm{Ga}$. The expansion of the Co reservoir between 2.8 and $1.8 \mathrm{Ga}$ (Fig. 8) may be coincident with increased mantle plume activity and associated hydrothermal inputs (Swanner et al., 2014). This expansion is also broadly consistent with an increase in genes that bind Co around this time (David and Alm, 2011). Such conditions simultaneously allow for the establishment of the ferruginous conditions necessary for IF precipitation and an increase in the amount of Co introduced to the ocean. Pervasive anoxic conditions would help keep Co in solution, and as such the residence time of Co would be higher in more anoxic oceans compared to modern, welloxygenated oceans (c.f., Swanner et al., 2014; also Saito and Moffett, 2002). This is consistent with the relatively high Co concentrations in the anoxic ferruginous waters of Lake Matano compared to its oxic surface waters (Crowe et al. 2008). However, the syngenetic and early diagenetic pyrite record for Co presented by Large et al. (2014) indicates a steadier decline in Co levels from $3 \mathrm{Ga}$ to present. Resolving the discrepancy between the IF and pyrite records would be of great interest, and is an area where a more complete black shale record may prove useful in resolving the temporal trends in marine Co from the Archean through to the modern. If the pyrite record for Co proves correct in predicting the overall trajectory, it will be quite telling, as this would then mirror the 
general trajectories for $\mathrm{Fe}$ and $\mathrm{Mn}$ as well, and may offer support for trace element variations as correlative to large igneous province events.

\subsection{Chromium}

Although chromium $(\mathrm{Cr})$ has been identified as a biological component in some higherlevel organisms, it is generally regarded as a toxin (Frausto da Silva and Williams, 2001). As such, temporal trends in seawater are unlikely to mirror direct evolutionary controls. Rather, investigations in the sedimentary record have focused on $\mathrm{Cr}$ abundances and isotope compositions for tracking oxygenation as well as the impact of anaerobes in the surface environment. This utility is due to reduced $\mathrm{Cr}$ in the form of $\mathrm{Cr}(\mathrm{III})$ being effectively immobile at neutral to alkaline $\mathrm{pH}$; $\mathrm{Cr}$ becomes mobile when it is oxidized to $\mathrm{Cr}(\mathrm{VI})$. Furthermore, $\mathrm{Cr}$ is subject to strong stable isotope fractionation during redox reactions, especially reduction (Ellis et al., 2002). As such, variations in $\mathrm{Cr}$ abundances and isotopic compositions are likely to represent changes in the redox state of the oceans or atmosphere, as well as associated changes in the mechanisms of $\mathrm{Cr}$ mobility and changes in sediment provenance.

Reinhard et al. (2013b) investigated $\mathrm{Cr}$ and Mo enrichments in anoxic and euxinic shales, coupling these two elemental systems in order to constrain the extent of anoxia versus euxinia in the early oceans. For $\mathrm{Cr}$, there are no significant authigenic enrichments in middle Proterozoic black shales and this was taken to indicate pervasive anoxia (Fig. 9). Conversely, Mo is enriched in middle Proterozoic black shales to an intermediate degree relative to Archean and Phanerozoic samples (Fig. 5), which indicates the

presence of euxinic conditions that were relatively limited on the seafloor-although still 
far greater than the extents observed today. This distinction is the result of differences in the geochemistry of $\mathrm{Cr}$ and Mo. Efficient burial of $\mathrm{Cr}$ can occur in sediments deposited under anoxic and ferruginous waters. By contrast, Mo burial, as discussed above, is most efficient in sediments deposited from euxinic waters. Together, these two elements can constrain the relative extent of ferruginous and euxinic conditions. In this regard, Reinhard et al. (2013b) estimated at least $30-40 \%$ of the middle Proterozoic seafloor was anoxic, and possibly much more, with only $1-10 \%$ of the seafloor being euxinic. Large et al. (2014) also investigated $\mathrm{Cr}$ and Mo concentrations in sedimentary pyrite and found patterns consistent with the dominance of anoxic settings in the Proterozoic from 2.15 to $0.7 \mathrm{Ga}$, with euxinic settings more prevalent between 1.2 and $0.8 \mathrm{Ga}$. Large et al. (2014) attributed a decrease in Cr concentrations, from the Archean to the Proterozoic (Fig. 9), as reflective of a change in source availability. They argued that $\mathrm{Cr}$ should be sourced from ultramafic rocks similar to $\mathrm{Ni}$ and $\mathrm{Co}$, and that this decrease may reflect a decrease in the abundance of the source (Fig. 9; also see their Fig. 8c).

Chromium isotope enrichments have also been used to track the oxygenation of the atmosphere and oceans. For instance, small variations in $\mathrm{Cr}$ isotope composition in 2.8-2.6 Ga IF were first suggested to document brief pulses in atmospheric oxygen, which mobilized $\mathrm{Cr}$ via oxidative weathering and led to $\mathrm{Cr}$ sequestration in IF prior to the GOE (Frei et al., 2009). Those authors argued that increases in $\delta^{53} \mathrm{Cr}$ of +0.04 to $+0.29 \%$ in IFs at 2.7 , and again at $1.8 \mathrm{Ga}$, are the direct result of $\mathrm{Cr}(\mathrm{III})$ being oxidized to $\mathrm{Cr}(\mathrm{VI})$ and that oxidation of $\mathrm{Cr}$ must have been catalyzed by oxidized $\mathrm{Mn}^{2+}$ in the form of $\mathrm{MnO}_{2}$. Subsequently, Konhauser et al. (2011) examined temporal trends in the degree of $\mathrm{Cr}$ enrichment in IF and found a peak at 2.48-2.32 Ga (Fig. 10). This peak was suggested 
to indicate the onset of acidic weathering triggered by microaerophilic iron-oxidizing bacteria which accelerated the weathering of pyrite as soon as some atmospheric oxygen became available. Muted $\delta^{53} \mathrm{Cr}$ variations $(-0.3$ to $+0.3 \%$ ) at this time were taken as being indicative of $\mathrm{Cr}$ cycling in reduced form (Konhauser et al., 2011), in contrast with highly variable values coincident with ocean oxygenation in the Neoproterozoic (up to +4.9\%; Frei et al., 2009).

Chromium isotope data were also acquired from rocks from the Pongola Supergroup, South Africa, in an effort to seek evidence for earlier signs of photosynthetic oxygen production. Crowe et al. (2013) found that the $\delta^{53} \mathrm{Cr}$ isotope compositions of 2.96 Ga paleosols were fractionated relative to the crustal values, indicating oxidative mobilization of $\mathrm{Cr}$ and the presence of low levels of atmospheric oxygen $\left(\sim 10^{-4} \mathrm{PAL}\right.$; the level required to prevent reduction of $\mathrm{Cr}[\mathrm{VI}]$ by $\mathrm{Fe}[\mathrm{II}]$ during transport to the ocean). This conclusion would suggest the presence and activity of oxygenic photosynthesis about $\sim 600$ million years prior to S-MIF disappearance during the GOE. The idea of early $\mathrm{O}_{2}$ production is supported by the Mo isotope composition of IF also obtained from within the Pongola Supergroup, where scaling between Mo isotope composition and $\mathrm{Mn} / \mathrm{Fe}$ ratio indicate the presence of a Mn(IV) oxide exit channel for Mo at that time (Planavsky et al., 2014b). However, it is also plausible that the Cr isotope fractionation observed by Crowe et al. (2013) in the $2.96 \mathrm{Ga}$ paleosols is due to the localized production of oxygen by cyanobacteria within a microbial mat (see Lalonde and Konhauser, 2015). In either case, the sedimentary Cr record, in terms of abundance and especially in isotopic composition, appears to provide important clues regarding oxygen production due to photosynthesis either in the early oceans, or on land, and corresponding 
oxidative weathering on the early continents. Investigations into the isotopic record of $\mathrm{Cr}$ in black shales and IF may continue to be a useful tracer for paleoredox conditions in the Precambrian oceans.

Recently, Planavsky et al. (2014a) presented $\delta^{53} \mathrm{Cr}$ data from Precambrian and Phanerozoic ironstones, as well as Neoproterozoic to Phanerozoic black shales and mudstones. Collectively, this record shows that $\delta^{53} \mathrm{Cr}$ values in Precambrian black shales are similar in composition to crustal $\mathrm{Cr}$ until the Neoproterozoic. Beginning approximately $0.8 \mathrm{Ga}$, relatively large positive $\delta^{53} \mathrm{Cr}$ values are observed in black shales and mudstones, as well as in some Phanerozoic ironstones. Those authors interpreted these trends in $\delta^{53} \mathrm{Cr}$ to suggest that atmospheric oxygen levels were $<0.1 \%$ PAL (below this level, $\mathrm{Cr}[\mathrm{III}]$ oxidation is limited by the lack of $\mathrm{Mn}$ oxides) prior to the Neoproterozoic. This concentration would have been limiting for metazoans, potentially explaining the delay in their diversification (although see Zhang et al. (2016) for an alternative opinion, as well as a comment on the opposing view by Planavsky et al. (2016)). The capacity of $\delta^{53} \mathrm{Cr}$ from shales and ironstones to resolve changes in oceanic oxygenation state depends on ability to discriminate authigenic from detrital $\mathrm{Cr}$, and this stands as a key challenge and opportunity. Nevertheless, the $\mathrm{Cr}$ record links biological and geochemical evolution indirectly via the effect that $\mathrm{O}_{2}$ has on both.

In an effort to establish a more rigorous calibration of the $\mathrm{Cr}$ isotope redox proxy in the modern, Reinhard et al. (2014) examined $\mathrm{Cr}$ isotope fractionations in the recent sediments of the Cariaco Basin, Venezuela. A slight increase in $\delta^{53} \mathrm{Cr}$ coupled with elevated $\mathrm{Cr}$ enrichments is coincident with the onset of deep-water euxinic conditions in the basin. The authors argued that this observation suggests that such sediments, and their 
ancient equivalents, can be used to track the $\mathrm{Cr}$ isotope composition of the oceans over time-because the $\delta^{53} \mathrm{Cr}$ signature of the overlying water column is approximately recorded by sediments deposited under an anoxic water column. Similar evidence of the reliability of black shales in tracking $\delta^{53} \mathrm{Cr}$ signatures is presented by Gueguen et al. (2016) from the upwelling zone of the Peru Margin, comparable to modern deepwater values. However, Scheiderich et al. (2015) recommended a more cautious approach to $\mathrm{Cr}$ isotope proxies based on important variability in $\mathrm{Cr}$ concentrations and isotopic compositions in the Arctic ocean and between the Arctic, Atlantic, and Pacific Oceans, emphasizing the need to better understand modern marine $\mathrm{Cr}$ cycling.

Most recently, Cole et al. (2016) have expanded the record of black shale $\delta^{53} \mathrm{Cr}$ values throughout Earth history, illustrating a base-level shift at $\sim 850$ Ma from largely unfractionated $\delta^{53} \mathrm{Cr}$ values similar to the composition of continental crust to highly fractionated $\delta^{53} \mathrm{Cr}$ values. The authors have used this record to suggest a lack of significant terrestrial oxidative weathering of $\mathrm{Cr}$ prior to $850 \mathrm{Ma}$ indicative of oxygen levels below $\sim 0.1 \%$ PAL (based on the pO2 estimate from Planavsky et al., 2014). Again, capacity to constrain authigenic versus detrital $\mathrm{Cr}$ is key to these interpretations.

\subsection{Iodine}

The history of iodine (I) cycling through time is biologically relevant, as its redox transformations occur at oxygen levels similar to proposed minimal requirements of early animals. Under anoxic conditions iodine occurs in the form of iodide $\left(\mathrm{I}^{-}\right)$, which is excluded from the crystal lattice of carbonates during their precipitation. When dissolved oxygen concentrations are $\geq 1 \mu \mathrm{M}$, iodate $\left(\mathrm{IO}_{3}^{-}\right)$is formed (Farrenkopf and Luther III, 
2002; Luther III and Campbell, 1991; Rue et al., 1997) and is incorporated into carbonate minerals (Lu et al., 2010). This relationship suggests that the simple presence of iodine in carbonate indicates the presence of $\mathrm{O}_{2}>1 \mu \mathrm{M}$ at the site of carbonate precipitation, i.e., in surface waters (Hardisty et al., 2014). This level of dissolved $\mathrm{O}_{2}$ in surface waters is generally consistent with the $0.1-1 \%$ PAL proposed as necessary for early animals (Mills et al., 2014; Sperling et al., 2013). However, the level of oxygen at depth remains unconstrained by the I record, and may still have posed a challenge to complex life.

A study of iodine concentrations in the carbonate record from the Neoarchean through Paleoproterozoic, indicate oxidation of the surface coincident with the GOE. This is reflected by a switch from the absence to presence of carbonate-bound iodine (Hardisty et al., 2014). Such a record indicates the potential for habitable marine environments, at least in terms of minimum $\mathrm{O}_{2}$ thresholds, hundreds of millions of years before the first evidence for animal life or eukaryotic diversification (Gingras et al., 2011; Knoll, 2014). However, records of iodine through time are currently limited, with measurements lacking through most of the Proterozoic and Paleozoic.

Beyond redox chemistry at biologically critical $\mathrm{O}_{2}$ levels, iodine is a bioessential element (Frausto da Silva and Williams, 2001), specifically within marine algae that accumulate iodine primarily in the form of iodide to reach total iodine concentrations up to several hundred ppm (Elderfield and Truesdale, 1980; Fuse et al., 1989; Muramatsu and Hans Wedepohl, 1998). These values are far greater those found in limestones (a few ppm) (Lu et al., 2010; Muramatsu and Hans Wedepohl, 1998; Zhou et al., 2014; 2015), and this organically bound iodine can ultimately end up as a component of organic-rich rocks, particularly black shales, where iodine-to-carbon ratios are slightly elevated 
relative to those found in algae: $\sim 1-5 \times 10^{-4}$ (Elderfield and Truesdale, 1980). However, most of the original organic-bound iodine is lost through diagenetic carbon remineralization (Kennedy and Elderfield, 1987). The reason for such high concentrations in marine algae is still unclear, but at least one primary role is as an antioxidant (Küpper et al., 1988; Venturi et al., 2000). It has been shown that brown algae assimilate iodine as iodide, which is excreted to react with ozone and other reactive oxygen species, providing protection against oxidative stress (Küpper et al., 1988). Regardless of this and other roles, the end result is that biological assimilation and burial act as the main marine iodine sink, with no known quantitatively important mineralogical sinks. Diagenesis of organic matter is thought to release $>99 \%$ of bound iodine back to seawater, such that internal cycling dominates the marine iodine budget; contributions from continental weathering and hydrothermalism appear negligible today ( $\mathrm{Lu}$ et al., 2010).

Though the redox requirements for the accumulation of marine iodate act as the primary control for $\mathrm{I} /(\mathrm{Ca}+\mathrm{Mg})$ ratios, the potential for carbonates to track changes in the marine iodine reservoir as well as the dominant iodine species in shallow ocean settings could provide a critical constraint on the evolution and abundance of marine algae through time. In oxyanion form, the halogens $\mathrm{Br}, \mathrm{Cl}$, and I are all relatively soluble, and one might predict that marine iodine concentrations relative to the bulk silicate Earth would be similar to that of $\mathrm{Br}$ and $\mathrm{Cl}$. However, normalized seawater is depleted in iodine by a factor of $\sim 40$ when compared to these other halogens (Sharp and Draper, 2013). This discrepancy can be explained by uptake and burial in association with marine algae, whose affinity for iodine is high relative to $\mathrm{Br}$ and $\mathrm{Cl}$ (Elderfield and Truesdale, 1980; 
Sharp and Draper, 2013), but this possibility requires that marine iodine concentrations have decreased through time. Perhaps decreases in marine iodine abundance through time occurred in pulses following the emergence and dominance of various algal clades? This pathway could be particularly relevant for the Proterozoic, where filamentous microfossils suggest red algae rhodophytes in carbonates up to 1200 Ma old (Butterfield, 2000; Knoll et al., 2013) and potential green algae chlorophytes as old as $1800 \mathrm{Ma}$ (Knoll, 2014; Moczydłowska et al., 2011).

Recent studies have tested the idea that organic carbon burial provides a secondary control on $\mathrm{I} /(\mathrm{Ca}+\mathrm{Mg})$ ratios on shorter timescales by evaluating $\mathrm{I} /(\mathrm{Ca}+\mathrm{Mg})$ in association with positive $\delta^{13} \mathrm{C}_{\text {carb }}$ excursions during Phanerozoic Oceanic Anoxic Events (OAE's), particularly OAE-2 (Lu et al., 2010; Zhou et al., 2015). The expectation is that if tracking the evolution of the iodine reservoir, $\mathrm{I} /(\mathrm{Ca}+\mathrm{Mg})$ ratios will systematically decrease to similar minimum values in global sections in step with contemporaneous $\delta^{13} \mathrm{C}_{\text {carb }}$ excursions. Though variable and particularly low $\mathrm{I} /(\mathrm{Ca}+\mathrm{Mg})$ ratios are observed in association with OAEs, these studies found that patterns and decreases in $\mathrm{I} /(\mathrm{Ca}+\mathrm{Mg})$ varied from section to section, and in most cases decrease prior to the $\delta^{13} \mathrm{C}$ excursionthe opposite of what is expected given that the residence time of iodine exceeds that of dissolved inorganic carbon by an order of magnitude (Broecker et al., 1982). Instead, the $\mathrm{I} /(\mathrm{Ca}+\mathrm{Mg})$ ratios may indicate a shift to low oxygen marine conditions prior to the $\mathrm{OAE}$, as defined by $\delta^{13} \mathrm{C}$ and black shale deposition. In other words, if changes in the total marine iodine reservoir coincide with anoxia, either locally or globally, this reservoir change may be unobservable because as $\mathrm{I} /(\mathrm{Ca}+\mathrm{Mg})$ exclusively tracks iodate ( $\mathrm{Lu}$ et al., 2010; Zhou et al., 2015). 


\subsection{Selenium}

In biological systems, selenium ( $\mathrm{Se}$ ) is found predominately in the alternative amino-acid selenocysteine, a cysteine analogue where the sulfur is replaced by selenium (Hatfield and Gladyshev, 2002). Selenocysteine is used in a variety of oxidoreductases involved in regulating oxidative stress, including methionine sulfoxide reductase and glutathione peroxidase. The proliferation of selenoproteins in select lineages, including the smallest free living eukaryote, Ostreococcus, has been suggested to be due to the selenocysteinecontaining proteins being more efficient than the corresponding cysteine version (Palenik et al., 2007). Recently, this possibility was shown to be true for a thioredoxin, with the selenocysteine version of the protein being 10-fold more catalytically active (Kim et al., 2015). Given these examples of Se utilization in biological systems, it is likely that Se plays a key role as a catalyst in intercellular processes.

The potential of Se and its stable isotopes as a paleo-redox tracer was first assessed by Johnson (2004) and Johnson and Bullen (2004), who calculated that significant stable isotope fractionation should occur during redox transformations between its four common valence states (VI, IV, 0, -II). Mitchell et al. (2012) examined Se abundances and $\delta^{82 / 76} \mathrm{Se}$ from a series of Cambrian to Holocene marine sediments and found significant variability in Se concentrations, but a narrow range of Se isotopes values (between -1 to $1 \%$ ). Since then, more complete compilations of Se through time have been presented from the pyrite record (Large et al., 2014), as well as marine and terrestrial mudrocks from the Archean through to the modern (Stüeken et al., 2015b). In their analyses of syngenetic and early diagenetic pyrite, Large et al. (2014) showed a 
temporal trend in Se with several small peaks at 3.0 and $2.4 \mathrm{Ga}$, along with a Paleoproterozoic to Mesoproterozoic perturbation between 1800-1300 Ma, and finally a rise in the Neoproterozoic to Phanerozoic. Large et al. (2014) further suggested that this trend in Se may be used as a paleoproxy for tracking oxygenation. Those same authors also suggested that the peak in Se at $\sim 3.0 \mathrm{Ga}$ in the pyrite record is consistent with $\mathrm{Cr}$ and Mo isotope data at that time (Crowe et al., 2013; Planavsky et al., 2014b). Accordingly, the pyrite record would then indicate low levels of $\mathrm{O}_{2}$ in the Proterozoic, although with some variability, before the onset of widespread ocean oxygenation in the Neoproterozoic.

Stüeken et al.'s examination of the Se cycle and its redox dynamic shed light on a number of aspects related to the oxygenation of the Earth, and we highlight a few key findings here. First, Stüeken et al. (2015b) suggested that increasing marine Se and S levels, and differences between terrestrial and marine settings between 2.8-2.7 Ga, imply that there was terrestrial oxidative weathering at that time. In 2.8-2.7 Ga non-marine samples, Stüeken et al. (2015b) found negatively fractioned $\delta^{82 / 76}$ Se values, as opposed to coeval marine samples which are generally positive, and this negative fractionation was attributed to oxidative weathering in terrestrial settings. Second, despite having several redox states, there is no evidence for mass-independent fractionation (MIF) of Se prior to the GOE. A general absence of Se-MIF is consistent with the findings of Pogge von Strandmann et al. (2014) who examined a small suite of 2.65-2.5 Ga black shales from the Ghaap Group in South Africa which had previously shown large S-MIF signals and should have been favorable for recording a Se-MIF signal, if one existed. Third, there is a decrease in sedimentary $\delta^{82 / 78} \mathrm{Se}$ values during the period between the middle Proterozoic 
and the mid-Paleozoic, which Stüeken et al. (2015b) attributed to the oxygenation of the deep ocean in the Neoproterozoic. Pogge von Strandmann et al. (2015) also examined the Se isotope record in the Neoproterozoic and found declining $8^{82 / 76} \mathrm{Se}$ values in black shales that they attributed to a protracted oxygenation of the ocean-atmosphere system between $\sim 770 \mathrm{Ma}$ and the early Cambrian.

Se isotope analyses have also been used to infer the presence of free $\mathrm{O}_{2}$ in the Neoarchean (Stüeken et al., 2015c). Selenium isotopes were measured on samples from the $2.5 \mathrm{Ga}$ Mt. McRae shale where Anbar et al. (2007) first reported a pre-GOE 'whiff' of oxygen. A peak in $\delta^{82 / 78} \mathrm{Se}$ and Se enrichment factors led Stüecken et al. (2015c) to suggest oxidative mobilization and fractionation of Se from terrestrial sources, similar to the conclusions of Anbar et al. (2007), Reinhard et al. (2009), Duan et al. (2010), and Kendall et al. (2015b), based on S-Mo-Re-Os systematics in the same horizon.

Selenium has also garnered interest in more recent sediments for its possible implications regarding biological activity in the Phanerozoic, especially its chemistry coincident to mass extinctions. Several global mass extinctions in the Phanerozoic have been correlated to severe Se depletion in the pyrite record, including the end-Ordovician, -Devonian and -Triassic events (Long et al., 2016). Coincident with these extinctions the pyrite record shows a dramatic decrease in Se, almost two orders of magnitude, suggesting that organisms relying on Se for biological functions may have become stressed, and that this may have been a contributing factor in the extinctions. Selenium has also provided clues for other Phanerozoic mass extinctions. For instance, Stüeken et al. (2015d) interpreted a profile from an outcrop in southern Alberta, Canada to indicate a brief period of euxinia, followed by a highly productive oxic period before the end- 
Permian mass extinction. They observed a large negative $\delta^{82 / 76} \mathrm{Se}$ excursion and interpreted it to reflect a large export of organic Se to the sediments immediately prior to the extinction, suggesting that productivity was high and nutrient limitation was likely not a cause of the extinction, at least locally. However, Stüeken et al. (2015d) do suggest that nutrient limitation may have played a role in the recovery from the mass extinction. In these ways we can see how Se evidence in black shales and pyrite may shed light on more recent evolutionary events in marine geochemical and biological evolution.

\subsection{Uranium}

The redox-sensitive element uranium (U), though not bioessential, provides constraints on the dynamics of the evolving oxygenation of the Earth. Some bacteria catalyze the reduction of $\mathrm{U}(\mathrm{VI})$ to $\mathrm{U}(\mathrm{IV})$ in order to obtain energy, including a few dissimilatory Fe(III)- and sulfate-reducing bacteria (e.g., Lovley et al., 1991, Behrends and Van Cappellen, 2005). Microbial U(VI) reduction, in addition to abiotic mechanisms of reduction such as sorption to organic matter or co-precipitation with iron oxides, sequesters marine $U$ into sediments. These processes provide a means to use $U$ concentration in the sedimentary record as a proxy for changes in the oxygen content of the atmosphere-ocean system. In terms of the sedimentary record, $U$ abundances have been investigated in both the IF and black shale records (Partin et al. (2013a,b), respectively, while $U$ isotopes have been used in some studies to better illuminate the oxygenation of the oceans (Asael et al., 2013; Kendall et al., 2013, 2015a; Dahl et al., 2014). More recent work has also demonstrated that $U$ isotopes can potentially be used to 
track the biotic reduction of $\mathrm{U}(\mathrm{VI})$, providing the potential for a novel redox biosignature proxy in the rock record (Stylo et al., 2015).

Temporal changes in $\mathrm{U}$ abundances in the IF and black shale datasets provide highly complementary records that document the rise and accumulation of oxygen associated with the GOE and yield insights into post-GOE oxygen dynamics (Partin et al., 2013a,b). An increase in U concentration and U/Fe ratios is observed in the IF record around 2.47-2.43 Ga and appears to mark the onset of the GOE—corroborated by a peak in both BIF and black shale U concentrations by $2.32 \mathrm{Ga}$ (Fig. 11). Following this initial peak, $\mathrm{U}$ and $\mathrm{U} / \mathrm{Fe}$ ratios in the $\mathrm{IF}$ record return to low levels during the late Paleoproterozoic (post $2.05 \mathrm{Ga}$ ), until an increase is observed in Neoproterozoic IF and Phanerozoic ironstones (Partin et al., 2013a). In the black shale record (Fig. 11), the rise in oxygen associated with the GOE is reflected in a marked increase in $\mathrm{U}$ and U/TOC values, followed by a dramatic decrease in the late Paleoproterozoic and a second increase in the latest Neoproterozoic - consistent with pervasive ocean and atmosphere oxygenation. This rise and fall in oxygen levels in the Paleoproterozoic is now the generally accepted paradigm in the evolution of the oxygenation of the Earth's surface (see Lyons et al., 2014a), though the biological implications of these events have only begun to be considered. However, laser ablation analyses of black shale matrices by Large et al. (2014) seem to show an increase in U during the Mesoproterozoic, with a peak between 1.4 to $1.7 \mathrm{Ga}$ (see their $8 \mathrm{c}$ ). They attribute this rise to enhanced oxidative weathering of U-rich granites. Although, they also show a peak with a similar maximum at 3.1 Ga which is difficult to reconcile with either interpretation of Proterozoic U abundances. Recent work using U-Th- $\mathrm{Pb}$ systematics (corrected U concentrations) and 
$\delta^{56} \mathrm{Fe}$ values from the $3.2 \mathrm{Ga}$ Manzimnyama IF in South Africa are consistent with ambient dissolved oxygen concentrations between 0.4 and $10 \mu \mathrm{M}$ (Satkoski et al., 2015).

Uranium isotopes have also been used to study the oxygenation of Earth's surface, since $\mathrm{U}$ isotope fractionations are linked to changes in the oxidation state of U. Evidence from $U$ isotopes $\left(\delta^{238} \mathrm{U}\right)$ in the Mt. McRae shale suggest $\mathrm{U}(\mathrm{IV})$ oxidation and mobilization as early as $2.5 \mathrm{Ga}$ (Kendall et al., 2013). They attributed $\delta^{238} \mathrm{U}$ values above average upper crustal values that coincide with Mo and Re enrichments (Anbar et al., 2007) to be indicative of the oxidative mobilization of $U$, possibly within the water column itself. In the late Paleoproterozoic, coupled U, Mo, and Fe isotope analyses in the 2.05 Ga Zaonega Formation suggest euxinic depositional conditions-showing values similar to those found in modern euxinic settings (Asael et al. 2103). This low redox state is consistent with a decrease in oxygenation of the atmosphere-ocean system following the GOE, as inferred for the late Paleo- to Mesoproterozoic from the black shale U abundance record (Partin et al., 2013b). Similarly, Kendall et al. (2015a) used coupled U and Mo isotopes from the Ediacaran Doushantuo Formation to examine ocean oxygenation dynamics around the time of metazoan diversification. High $\delta^{238} U$ values indicate pervasive ocean oxygenation between 560-551 Ma. Collectively, studies such as these have demonstrated the utility in using U, a non-bioessential element, for tracking the redox evolution of the Earth's atmosphere and oceans. This, in turn, has profound effects for the evolution of the biosphere, and perhaps even for tracking the biotic signature of $U$ reduction in the rock record (Stylo et al., 2015).

\section{Future work}




\subsection{General directions}

The study of trace element concentrations in sedimentary archives through geological time is a relatively young field, and only a handful of bioessential trace elements have been investigated in the sedimentary records - IF, black shale, and pyrite (Figs. 3 and 12). Additionally, other sedimentary rock types that might serve as proxies for ancient ocean trace element concentrations - chert and carbonates - demand further study, including potential overprints during diagenesis and later burial. Chert and carbonate records have yet to be extensively explored, and are poised to provide further insights on paleomarine trace element abundances. When viewed through a genomic lens in terms of metalloenzyme evolution and diversification, the constraints imposed by geochemical modeling and the paleomarine proxy record should significantly improve our understanding of the links between evolving marine geochemistry, Earth surface redox conditions, and early biological evolution (Fig. 12).

\subsection{Metals remaining to be investigated}

Specific avenues for future work that would be of immediate interest include examining the sedimentary proxy records for temporal trends in bioessential elements that have yet to be fully explored. Two in particular, copper $(\mathrm{Cu})$ and vanadium $(\mathrm{V})$, stand out in this respect. Copper is used in 'blue' copper proteins for electron transfer, energy capture, and in other oxidative enzymes (e.g., Solomon et al., 1996). The emergence of Cumetalloproteins is thought to have been quite late (Dupont et al., 2010). Similar to Zn, thermodynamic modeling indicates that the seawater $\mathrm{Cu}$ reservoir should have reached a low in Proterozoic oceans as the result of expanded water column euxinia (e.g., Frausto 
da Silva and Williams, 2001; Saito et al., 2003). However, recent examination of authigenic $\mathrm{Cu}$ enrichments in BIF and black shales, normalized to detrital input using $\mathrm{Ti}$, are remarkably static throughout the Precambrian (Chi-Fru et al., 2016). Despite the static abundance record, there is significant variation in black shale $\mathrm{Cu}$ isotope compositions over time that appears to be due to variations in $\mathrm{Cu}$ sinks and sources (Chi-Fru et al., 2016). The preferential sequestration of ${ }^{65} \mathrm{Cu}$ by iron oxides (e.g., Balistrieri et al., 2008) likely enriched seawater in residual ${ }^{63} \mathrm{Cu}$, which would have been incorporated into planktonic biomass and ultimately deposited into black shales depleted in ${ }^{65} \mathrm{Cu}$. After the GOE, oxidative continental weathering of sulfides should have increased the supply of dissolved $\mathrm{Cu}(\mathrm{II})$ and delivered more ${ }^{65} \mathrm{Cu}$-rich runoff to the oceans, while at the same time the isotopically light sink associated with iron oxides waned. This evolution towards heavy $\delta^{65} \mathrm{Cu}$ values coincides with a shift to negative sedimentary $\delta^{56} \mathrm{Fe}$ values and increased marine sulfate after the GOE, and is traceable through Phanerozoic black shales to modern marine settings, where marine dissolved and sedimentary $\delta^{65} \mathrm{Cu}$ values are universally positive.

Zerkle et al. (2005) suggested that since the onset of widespread ocean oxygenation in the Neoproterozoic, the biological utilization of $\mathrm{Cu}$ enzymes doubled, likely as a result of increased $\mathrm{Cu}$ availability. In the modern ocean, $\mathrm{Cu}$-metalloproteins are involved in the first step of nitrification, last step of denitrification, and during ammonia oxidation; the net result is a substantial bacterial $\mathrm{Cu}$ requirement (Amin et al., 2013). Low seawater $\mathrm{Cu}$ concentrations and bioavailability may also have had significant implications for the Precambrian atmosphere. In this regard, Buick (2007) proposed that in a $\mathrm{Cu}$-limited ocean, denitrification would be incomplete since $\mathrm{Cu}$ is an essential 
component of the enzymes involved in that metabolism. The effect could have been a build-up of $\mathrm{N}_{2} \mathrm{O}$ with significant climatic implications because $\mathrm{N}_{2} \mathrm{O}$ is a potent greenhouse gas. The results of Chi-Fru et al. (2016) would seem to indicate that such a scenario was unlikely, considering the relatively static sedimentary $\mathrm{Cu}$ abundance record they present. Additional work is required to understand how $\mathrm{Cu}$ abundances and stable isotopes respond to changes in ocean and atmosphere redox - and how the biological history of copper utilization fits into the evolving redox landscape.

Vanadium is also an important bioessential trace element for the early nitrogen cycle. Both Anbar and Knoll (2002) and Zhang et al. (2014) suggested that the V-Fe nitrogenase varieties might have contributed to nitrogen fixation during the Paleoproterozoic, although the V variety is less efficient (Eady, 1996). Correspondingly, Zhang et al. (2014) indicated that low $\delta^{15} \mathrm{~N}$ values in Archean cherts may be more consistent with alternative nitrogenases using Fe or V instead of Mo, suggesting a more important role for these variants in deep time - an interpretation challenged by the recent work of Stüeken et al. (2015a) (see section 3.2). A preliminary trend for V in euxinic black shales through time was presented in Sahoo et al. (2012) (see their figure 3b). It was argued that seawater $\mathrm{V}$ concentrations were low in the mid-Proterozoic, and that $\mathrm{V}$ enrichments in the Doushantuo Formation ( 635-630 Ma) were consistent with a welloxygenated ocean. Overall, it appears that the black shale record for V mirrors that of Mo, and is relatively consistent with Neoproterozoic enrichments seen in the pyrite record (Large et al., 2014). However, the IF archives have not yet been investigated, and an extensive temporal examination of $\mathrm{V}$ in the context of its biological importance is 
lacking. Further, and perhaps most importantly, the cellular stoichiometry and specific requirements for $\mathrm{V}$ remain unclear.

Collectively, the temporal trends of $\mathrm{Mo}, \mathrm{V}$, and potentially $\mathrm{Cu}$, suggest a scenario where $\mathrm{N}$-fixing cyanobacteria in the early oceans may have been affected by biolimiting levels of multiple trace metals, especially prior to the GOE. As such, an understanding of $\mathrm{Cu}$ and $\mathrm{V}$ will be essential in order to obtain a complete picture of the $\mathrm{N}$ cycle prior to Neoproterozoic ocean oxygenation. The evolving picture for widespread nitrogen fixation on the early Earth is becoming more sophisticated and complex, and ultimately may have been influenced by the intricate interplay of several key trace metals in the early oceans.

Additional biologically relevant elements whose concentrations in sedimentary archives have not yet been investigated on billion-year timescales (Fig. 3) include cadmium (Cd) and tungsten (W). In the case of $\mathrm{Cd}$, the black shale and sedimentary pyrite records may be of special interest because Cd-sulfides have recently been identified as an important sink from oxygen-deficient water columns (Janssen et al., 2014). Cadmium has been shown to stimulate Thalassiosira weissflogii under $\mathrm{Zn}$ limiting conditions because it is used in an alternative form of carbonic anhydrase, the enzyme that facilitates the interconversion of dissolved bicarbonate to $\mathrm{CO}_{2}$, and vice versa (Lane and Morel, 2000). Tungsten is used by primitive anaerobic prokaryotes and mostly filled roles now played by Mo (Williams et al., 2002; Pushie et al., 2014). Hence, W may also play a key role in the biogeochemical cycling of $\mathrm{N}$ prior to the Neoproterozoic. In modern bacteria and archaea, $\mathrm{W}$ is generally important for hyperthermophiles, suggesting that $\mathrm{W}$ bioavailability may have been critical for early life given the ancient origin of 
these organisms. In modern extant lineages, it may also fill biological roles by substituting for Mo (e.g., Frausto da Silva and Williams, 2001; L’vov et al., 2002).

Finally, explaining the continued utilization of $\mathrm{Fe}$ (and $\mathrm{Mn}$ ) in biology despite decreasing seawater concentrations and bioavailability from the Archean to the Phanerozoic (Zerkle et al., 2005) is of great interest to biogeochemists. There are several pathways that have evolved to utilize alternative trace metals in place of Fe (see below). Dissolved Fe concentrations in the Archean and Paleoproterozoic oceans would have had to have been high in order to permit the formation of extensive IF via Fe(II) oxidation by anoxygenic and oxygenic photosynthesis (Bekker et al., 2010). However, Anbar and Knoll (2002) suggested that declining seawater $\mathrm{Fe}$ concentrations after the Paleoproterozoic, triggered by the increased precipitation of Fe-oxides and sulfides (Canfield, 1998), may have suppressed the activity of nitrogenase (whose different versions all depend on $\mathrm{Fe}$ ), and in turn, potentially limited Mesoproterozoic primary productivity via a dearth of fixed $\mathrm{N}$.

High dissolved concentrations of $\mathrm{Fe}$ in Archean seawater may have also directly impacted the activity of cyanobacteria. Swanner et al. (2015) showed that for cyanobacteria cultured under high-Fe conditions, there is an increase in destructive reactive oxygen species (ROS) produced in the cell; indeed, they reported a two-fold increase in ROS at $100 \mu \mathrm{M} \mathrm{Fe(II)} \mathrm{and} \mathrm{a} \mathrm{five-fold} \mathrm{increase} \mathrm{at} 1000 \mu \mathrm{M} \mathrm{Fe}(\mathrm{II})$. These ROS would have negatively affected the survival of early cyanobacteria, potentially delaying the proliferation of oxygenic photosynthesis prior to the GOE. However, despite declining Fe concentrations following the final Paleoproterozoic episode of widespread IF deposition at $1.88 \mathrm{Ga}$ (Rasmussen et al., 2012), Fe utilization in biological systems 
remains high. Several recent molecular innovations are employed by organisms in the modern environment to reduce Fe requirements - but always with a tradeoff. These tradeoffs include the replacement of a Fe-containing superoxide dismutase with a $\mathrm{Ni}$ containing version (Dupont et al., 2012), exchanging an Fe protein with a $\mathrm{Cu}$ protein in the electron transport chains in photosynthesis (Peers and Price, 2006) and ammonia oxidation (Santoro et al., 2015), and using $\mathrm{B}_{12}$ instead of Fe for ribonucleotide reductase. In all cases, the exchange necessitates the acquisition of a different micronutrient. Declining Fe concentrations may also have stimulated the evolutionary development of organic ligand complexes, such as siderophores, that target elements such as Fe for facilitated acquisition (Hider, 1984; Neilands, 1989; Kendall et al., 2012).

\section{Conclusions}

There has been significant progress made in recent years in the examination of sedimentary proxy records (black shales, IF, pyrite) for the paleomarine availability of biologically critical trace elements, including $\mathrm{P}, \mathrm{Mo}, \mathrm{Ni}, \mathrm{Zn}, \mathrm{Cr}$, and $\mathrm{Co}$ (Fig. 12). In several instances, fundamental differences between thermodynamic based solubility models and the sedimentary proxy record highlight the need for a multi-disciplinary approach when evaluating paleomarine trace element abundances. As such, updated geochemical models should accompany future studies of the sedimentary proxy record in order to provide parsimonious explanations for paleomarine concentrations and resultant biological implications. It is critical in studies of the temporal trends of bioessential trace elements and organismal stoichiometries to consider both thermodynamic and kinetic controls on the composition of seawater. Collectively, studies on the proxy record thus far 
indicate that there is a complex and dynamic interplay between biological and geochemical processes that have not only affected the composition of Earth's surface through time, but the evolution of life as well.

\section{Acknowledgements}

LJR gratefully acknowledges the support of a Vanier Canada Graduate Scholarship. Discovery Grants from the Natural Sciences and Engineering Research Council of Canada (NSERC) to CAP, BK, DSA, SAC, and KOK supported this work. This material is based upon work supported by the National Aeronautics and Space Administration through the NASA Astrobiology Institute under Cooperative Agreement No. NNA15BB03A issued through the Science Mission Directorate. NJP receives support from the Alternative Earths NASA Astrobiology Institute. Funding from the NASA Astrobiology Institute, and the NSF FESD and ELT programs to TWL, and the Region of Brittany and LabexMER funding to SVL are also gratefully acknowledged. AB thanks the Society of Independent Thinkers. The authors thank two anonymous reviewers for comments that greatly improved the manuscript, and Dr. Karsten Pedersen for his editorial efforts.

\section{References}

Aguirre, J.D., Clark, H.M., Mcllvin, M., Vazquez, C., Palmere, S.L., Grab, D.J., Seshu, J., Hart, P.J., Saito, M., Culotta, V.C., 2013. A manganese-rich environment supports superoxide dismutase activity in a Lyme disease pathogen, Borrelia burgdorferi. J. Biol. Chem. 288: 8468-8478.

Ahlgren, N.A., Noble, A., Patton, A.P., Roache-Johnson, K., Jackson, L., Robinson, D., McKay, C., Moore, L.R., Saito, M.A., Rocap, G., 2014. The unique trace metal and mixed layer conditions of the Costa Rica upwelling dome support a distinct dense community of Synechococcus. Limnol. Oceanogr. 59: 2166-2184. 
Alexander, B., Bau, M., Andersson, P., Dulski, P., 2008. Continentally-derived solutes in shallow Archean seawater: Rare earth element and $\mathrm{Nd}$ isotope evidence in iron formation from the 2.9 Ga Pongola Supergroup, South Africa. Geochim. Cosmochim. Acta 72: 378-394.

Algeo, T.J., Lyons, T.W., 2006. Mo-total organic carbon covariation in modern anoxic marine environments: Implications for analysis of paleoredox and paleohydrographic conditions. Paleoceanography 21: doi:10.1029/2004PA001112.

Algeo, T.J., Tribovillard, N., 2009. Environmental analysis of paleoceanographic systems based on molybdenum-uranium covariation. Chem. Geol. 268: 211-225.

Algeo, T.J., Rowe, H., 2012. Paleooceanographic application of trace-metal concentration data. Chem. Geol. 324-325: 6-18.

Allwood, A.C., Walter, M.R., Kamber, B.S., Marshall, C.P., Burch, I.W., 2006. Stromatolite reef from the Early Archaean era of Australia. Nature 441: 714-718.

Amin, S.A., Moffett, J.W., Martens-Habbena, W., Jacquot, J.E., Han, Y., Devol, A., Ingalls, A.E., Stahl, D.A., Armbrust, E.V., 2013. Copper requirements of the ammonia-oxidizing archaeon Nitrosopumilus maritimus SCM1 and implications for nitrification in the marine environment. Limnol. Oceanogr. 58: 2037-2045.

Anbar, A.D., 2008. Elements and Evolution. Science 322: 1481-1483.

Anbar, A.D., Duan, Y., Lyons, T.W., Arnold, G.L., Kendall, B., Creaser, R.A., Kaufman, A.J., Gordon, G.W., Scott, C., Garvin, J., Buick, R., 2007. A Whiff of Oxygen Before the Great Oxidation Event? Science, 317: 1903-1906.

Anbar, A.D., Knoll, A.H., 2002. Proterozoic ocean chemistry and evolution: A bioinorganic bridge? Science 297: 1137-1142.

Aristilde, L., Xu, Y., Morel, F.M.M., 2012. Weak Organic Ligands Enhance Zinc Uptake in Marine Phytoplankton. Environ. Sci. Technol. 46: 5438-5445.

Arnold, G.L., Anbar, A.D., Barling, J., Lyons, T.W., 2004. Molybdenum Isotope Evidence for Widespread Anoxia in Mid-Proterozoic Oceans. Science 304: 87-90.

Arnold, G.L., Lyons, T.W., Gordon, G.W., Anbar, A.D., 2012. Extreme change in sulfide concentrations in the Black Sea during the Little Ice Age reconstructed using molybdenum isotopes. Geology 40: 595-598.

Asael, D., Tissot, F.L.H., Reinhard, C.T., Rouxel, O., Dauphas, N., Lyons, T.W., Ponzevera, E., Liorzou, C., Chéron, S., 2013. Coupled molybdenum, iron, and uranium stable isotopes as oceanic paleoredox proxies during the Paleoproterozoic Shunga Event. Chem. Geol. 362: 193-210.

Bau, M., 1993. Effects of syn- and post-depositional processes on the rare-earth element distribution in Precambrian iron-formations. Eur. J. Mineral. 5: 257-267.

Bau, M., Möller, P., 1993. Rare earth element systematics of the chemically precipitated component in Precambrian iron formations and the evolution of the terrestrial atmosphere-hydrosphere-lithosphere system. Geochim. Cosmochim. Acta 57: 2239-2249.

Bau, M., Dulski, P., 1996. Distribution of yttrium and rare-earth elements in the Penge and Kuruman iron-formations, Transvaal Supergroup, South Africa. Precambrian Res. 79: 37-55.

Baldwin, G.J., Thurston, P.C., Kamber, B.S., 2011. High-precision rare earth element, nickel, and chromium chemistry of chert microbands pre-screened with in-situ analysis. Chem. Geol. 285: 133-143. 
Balistrieri, L.S., Borrok, D., Wanty, R., and Ridley, W., 2008, Fractionation of Cu and Zn isotopes during adsorption onto amorphous Fe(III) oxyhydroxide: Experimental mixing of acid rock drainage and ambient river water. Geochim. Cosmochim. Acta, 72: 311-328.

Banerjee, N.R., Furnes, H., Muehlenbachs, K., Staudigel, H., de Wit, M., 2006. Preservation of 3.4-3.5 Ga microbial biomarkers in pillow lavas and hyaloclastites from the Barberton Greenstone Belt, South Africa. Earth Planet. Sci. Lett. 241: 707-722.

Banerjee, N.R., Simonetti, A., Furnes, H., Muehlenbachs, K., Staudigel, H., Heaman, L., Van Kranendonk, M.J., 2007. Direct dating of Archean microbial ichnofossils. Geology 35: 487-490.

Behrends, T., Van Cappellen, P., 2005. Competition between enzymatic and abiotic reduction of uranium(VI) under iron reducing conditions. Chem. Geol. 220: 315327.

Bekker, A., 2014. Great Oxygenation Event, in: Encyclopedia of Astrobiology. Springer Berlin Heidelberg, Berlin, Heidelberg, pp. 1-9.

Bekker, A., Holland, H.D., Wang, P.-L., Ruble III, D., Stein, H.J., Hannah, J.L., Coetzee, L.L., Beukes, N.J., 2004. Dating the rise of atmospheric oxygen. Nature 427: 117120.

Bekker, A., Slack, J.F., Planavsky, N., Krapež, B., Hofmann, A., Konhauser, K.O., Rouxel, O.J., 2010. Iron Formation: The Sedimentary Product of a Complex Interplay among Mantle, Tectonic, Oceanic, and Biospheric Processes. Econ. Geol. 105: 467-508.

Bekker, A., Planavsky, N.J., Krapež, B., Rasmussen, B., Hofmann, A., Slack, J.F., Rouxel, O.J., Konhauser, K.O., 2014. Iron Formations: Their Origins and Implications for Ancient Seawater Chemistry in Holland, H.K., Turekian, K., (eds.) Treatise on Geochemistry, $2^{\text {nd }}$ edition: 561-628.

Bell, E.A., Boehnke, P., Harrison, T.M., Mao, W.L., 2015. Potentially biogenic carbon preserved in a 4.1 billion-year-old zircon. Proc. Natl. Acad. Sci. 112: 14518-14521.

Berg, J., Shi, Y., 1996. The Galvanization of Biology: A Growing Appreciation for the Roles of Zinc. Science 271: 1081-1085.

Berner, R.A., 1970. Sedimentary pyrite formation. Am. J. Sci. 268:1-23.

Bjerrum, C.J., Canfield, D.E., 2002. Ocean productivity before about 1.9 Gyr ago limited by phosphorus adsorption onto iron oxides. Nature 417: 159-162.

Bolhar, R., Kamber, B.S., Moorbath, S., Fedo, C.M., Whitehouse, M.J., 2004. Characterisation of early Archaean chemical sediments by trace element signatures. Earth. Planet. Sci. Lett. 222: 43-60.

Boyd, E.S., Anbar, A.D., Miller, S., Hamilton, T.L., Lavin, M., Peters, J.W., 2011. A late methanogen origin for molybdenum-dependent nitrogenase. Geobiology 9: 221232.

Brasier, M.D., Green, O.R., Jephcoat, A.P., Kleppe, A.K., Van Kranendonk, M.J., Lindsay, J.F., Steele, A., Grassineau, N.V., 2002. Questioning the evidence for Earth's oldest fossils. Science 416: 76-81.

Brasier, M.D., Lindsay, J.F., 1998. A billion years of environmental stability and the emergence of eukaryotes: New data from northern Australia. Geology 26: 555-558. 
Brand, L.E., Sunda, W.G., Guillard, R.R.L., 1983. Limitation of Marine Phytoplankton Reproductive Rates by Zinc, Manganese, and Iron. Limnol. Oceanogr. 28: 11821198.

Brocks, J.J., Logan, G.A., Buick, R., Summons, R.E., 1999. Archean Molecular Fossils and the Early Rise of Eukaryotes. Science 285: 1033-1036.

Brocks, J.J., Buick, R., Logan, G.A., Summons, R.E., 2003a. Composition and sygeneity of molecular fossils from the 2.78 to 2.45 billion-year-old Mount Bruce Supergroup, Pilbara Craton, Western Australia. Geochim. Cosmochim. Acta 67: 4289-4319.

Brocks, J.J., Buick, R., Summons, R.E., Logan, G.A., 2003b. A reconstruction of Archean biological diversity based on molecular fossils from the 2.78-2.45 billionyear-old Mount Bruce Supergroup, Hamersley Basin, Western Australia. Geochim. Cosmochim. Acta 67: 4321-4335.

Brocks, J.J., Summons, R.E., Buick, R., Logan, G.A., 2003c. Origin and significance of aromatic hydrocarbons in giant iron ore deposits of the late Archean Hamersley Basin, Western Australia. Org. Geochem. 34: 1161-1175.

Broecker, E.S., 1971. A Kinetic Model for the Chemical Composition of Sea Water. Quaternary Res. 1: 188-207.

Broecker, W.S., Peng, T.-H. and Beng, Z., 1982. Tracers in the Sea. Lamont-Doherty Geological Observatory, Columbia University. pp. 1-690.

Bruland, K., 1980. Oceanographic distributions of cadmium, zinc, nickel, and copper in the North Pacific. Earth Planet. Sci. Lett. 47: 176-198.

Bruland, K.W., 1989. Complexation of Zinc by Natural Organic Ligands in the Central North Pacific. Limnol. Oceanogr. 34, 269-285.

Bruland, K.W., Lohan, M.C., 2003. Controls of Trace Metals in Seawater. In Holland, H.K., Turekian, K., (eds.) Treatise on Geochemistry, $1^{\text {st }}$ edition, volume 6: 23-47.

Buick, R., 2007. Did the Proterozoic 'Canfield Ocean' cause a laughing gas greenhouse? Geobiology 5: 97-100.

Butterfield, N.J., 2000. Bangiomorpha pubescens n. gen., n. sp.: implications for the evolution of sex, multicellularity, and the Mesoproterozoic/Neoproterozoic radiation of eukaryotes. Paleobiology 26: 386-404.

Byrne, R. H., Kim K. -H., 1990. Rare earth element scavenging in seawater. Geochim. Cosmochim. Acta 54: 2645-2656.

Canfield, D.E., 1989. Reactive iron in marine sediments. Geochim. Cosmochim. Acta 53, 619-632.

Canfield, D.E., 1998. A new model for Proterozoic ocean chemistry. Nature 396: 450453.

Canfield, D.E., Poulton, S.W., Narbonne, G.M., 2007. Late-Neoproterozoic Deep-Ocean Oxygenation and the Rise of Animal Life. Nature 315: 92-95.

Canfield, D.E., Poulton, S.W., Knoll, A.H., Narbonne, G.M., Ross, G., Goldberg, T., Strauss, H., 2008. Ferruginous Conditions Dominated Later Neoproterozoic DeepWater Chemistry. Science 321: 949-952.

Chappaz, A., Lyons, T.W., Gregory, D.D., Reinhard, C.T., Gill, B.C., Li, C., Large, R.R., 2014. Does pyrite act as an important host for molybdenum in modern and ancient euxinic sediments? Geochim. Cosmochim. Acta 126: 112-122. 
Chen, X., Ling, H.-F., Vance, D., Shields-Zhou, G.A., Zhu, M., Poulton, S.W., Och, L.M., Jiang, S.-Y., Li, D., Cremonese, L., Archer, C., 2015. Rise to modern levels of ocean oxygenation coincided with the Cambrian radiation of animals. Nat. Commun. 6: 7142.

Chi-Fru, E., Rodríguez, N.P., Partin, C.A., Lalonde, S.V., Andersson, P., Weiss, D.J., Albani, El, A., Rodushkin, I., Konhauser, K.O., 2016. Cu isotopes in marine black shales record the Great Oxidation Event. Proc. Natl. Acad. Sci.113: 4941-4946.

Cole, D.B., Reinhard, C.T., Wang, X., Gueguen, B., Halverson, G.P., Gibson, T., Hodgskiss, M.S.W., McKenzie, N.R., Lyons, T.W., Planavsky, N.J., 2016. A shalehosted $\mathrm{Cr}$ isotope record of low atmospheric oxygen during the Proterozoic. Geology 44: 555-558.

Collier, R. W., 1985. Molybdenum in the Northeast Pacific Ocean. Limnology and Oceanography 30: 1351-1354.

Condie, K.C., 1993. Chemical composition and evolution of the upper continental crust: contrasting results from surface samples and shales. Chem. Geol. 104: 1-37.

Crusius, J., Calvert, S., Pedersen, T., Sage, D., 1996. Rhenium and molybdenum enrichments in sediments as indicators of oxic, suboxic and sulfidic conditions of deposition. Earth. Planet. Sci. Lett. 145: 65-78.

Crowe, S.A., O’Neill, A.H., Katsev, S., Hehanussa, P., Haffner, G.D., Sundby, B., Mucci, A., Fowle, D.A., 2008. The biogeochemistry of tropical lakes: A case study from Lake Matano, Indonesia. Limnol. Oceanogr. 53: 319-331.

Crowe, S.A., Døssing, L.N., Beukes, N.J., Bau, M., Kruger, S.J., Frei, R., Canfield, D.E., 2013. Atmospheric oxygenation three billion years ago. Nature 501: 535-538.

Czaja, A.D., Johnson, C.M., Roden, E.E., Beard, B.L., Voegelin, A.R., Nägler, T.F., Beukes, N.J., Wille, M. (2012) Evidence for free oxygen in the Neoarchean ocean based on coupled iron-molybdenum isotope fractionation. Geochim. Cosmochim. Acta 86: 118-137.

Dahl, T.W., Hammarlund, E.U., Anbar, A.D., Bond, D.P., Gill, B.C., Gordon, G.W., Knoll, A.H., Nielsen, A.T., Schovsbo, N.H., Canfield, D.E., 2010. Devonian rise in atmospheric oxygen correlated to the radiations of terrestrial plants and large predatory fish. Proc. Natl. Acad. Sci. 107: 17911-17915.

Dahl, T.W., Canfield, D.E., Rosing, M.T., Frei, R.E., Gordon, G.W., Knoll, A.H., Anbar, A.D., 2011. Molybdenum evidence for expansive sulfidic water masses in $\sim 750 \mathrm{Ma}$ oceans. Earth Planet. Sci. Lett. 311: 264-274.

Dahl, T.W., Boyle, R.A., Canfield, D.E., Connelly, J.N., Gill, B.C., Lenton, T.M., Bizzarro, M., 2014. Uranium isotopes distinguish two geochemically distinct stages during the later Cambrian SPICE event. Earth Planet. Sci. Lett. 401: 313-326.

David, L.A., Alm, E.J., 2011. Rapid evolutionary innovation during an Archaean genetic expansion. Nature 469, 93-96.

Davis, J. A., Coston, J. A., Kent, D. B., Fuller, C. C., 1998. Application of the surface complexation concept to complex mineral assemblages. Environ. Sci. Technol. 32: 2820-2828.

Dierssen, H., Balzer, W., Landing, W.M., 2001. Simplified synthesis of an 8hydroxyquinoline chelating resin and a study of trace metal profiles from Jellyfish Lake, Palau. Mar. Chem. 73: 173-192. 
Douville, E., Charlou, J.L., Oelkers, E.H., Bienvenu, P., Jove Colon, C.F., Donval, J.P., Fouquet, Y., Prieur, D., Appriou, P., 2002. The rainbow vent fluids $\left(36^{\circ} 14^{\prime} \mathrm{N}\right.$, MAR): the influence of ultramafic rocks and phase separation on trace metal content in Mid-Atlantic Ridge hydrothermal fluids. Chem. Geol. 184: 37-48.

Duan, Y., Anbar, A.D., Arnold, G.L., Lyons, T.W., Gordon, G.W., Kendall, B., 2010. Molybdenum isotope evidence for mild environmental oxygenation before the Great Oxidation Event. Geochim. Cosmochim. Acta 74: 6655-6668.

Dupont, C.L., Yang, S., Palenik, B., Bourne, P.E., 2006. Modern proteomes contain putative imprints of ancient shifts in trace metal geochemistry. Proc. Natl. Acad. Sci. USA 103: 17822-17827.

Dupont, C.L., Neupane, K., Shearer, J., Palenik, B., 2008. Diversity, function and evolution of genes coding for putative Ni-containing superoxide dismutases. Environ. Microbiol. 10: 1831-1843.

Dupont, C.L., Butcher, A., Valas, R.E., Bourne, P.E., Caetano-Anollés, G., 2010. History of biological metal utilization inferred through phylogenomic analysis of protein structures. Proc. Natl. Acad. Sci. USA 107: 10567-10572.

Dupont, C.L., Johnson, D.A., Phillippy, K., Paulsen, I.T., Brahamsha, B., Palenik, B., 2012. Genetic identification of a high-affinity Ni transporter and the transcriptional response to Ni deprivation in Synechococcus sp. strain WH8102. Appl. Envrion. Microbiol. 78: 7822-7832.

Dzombak, D. A., Morel, F. M. M., 1990. Surface complexation modeling Hydrous ferric oxide. John Wiley and Sons, pp 1-393.

Eady, R.R., 1996. Structure-Function Relationships of Alternative Nitrogenases. Chem. Rev. 96: 3013-3030.

Eickhoff, M., Obst, M., Schröder, C., Hitchcock, A.P., Tyliszczak, T., Martinez, R.E., Robbins, L.J., Konhauser, K.O., Kappler, A., 2014. Nickel partitioning in biogenic and abiogenic ferrihydrite: The influence of silica and implications for ancient environments. Geochim. Cosmochim. Acta 140: 65-79.

Eigenbrode, J.L., Freeman, K.H., 2006. Late Archean rise of aerobic microbial ecosystems. Proc. Natl. Acad. Sci. USA 103:15759-15764.

Elderfield, H., Truesdale, V.W., 1980. On the biophilic nature of iodine in seawater. Earth Planet. Sci.Lett. 50: 105-114.

Elderfield, H., Schultz, A., 1996. Mid-ocean ridge hydrothermal fluxes and the chemical composition of the ocean. Annu. Rev. Earth Planet. Sci. 24: 191-224.

Ellis, A.S., Johnson, T.M., Bullen, T.D., 2002. Chromium Isotopes and the Fate of Hexavalent Chromium in the Environment. Science 295: 2060-2062.

Emerson, S.R., Heusted, S.S., 1991. Ocean anoxia and the concentrations of molybdenum and vanadium in seawater. Mar. Chem. 34: 177-96.

Erel, Y., Stolper, E.M., 1993. Modeling of rare-earth element partitioning between particles and solution in aquatic environments. Geochim. Cosmochim. Acta 57: 513-518.

Erickson, B.E., Helz, G.R., 2000. Molybdenum (VI) speciation in sulfidic waters: stability and lability of thiomolybdates. Geochim. Cosmochim. Acta 64: 11491158 . 
Erwin, D.H., LaFlamme, M., Tweedt, S.M., Sperling, E.A., Pisani, D., Peterson, K.J., 2011. The Cambrian Conundrum: Early Divergence and Later Ecological Success in the Early History of Animals. Science 334: 1091-1097.

Eyles, N., Young, G.M., 1994. Earth's glacial record and geodynamic controls on glaciation in Earth history. In: Deynoux, M., Miller, J.M.G., Domack, E.W., Eyles, N., Fairchild, I.J., Young, G.M. (Eds.), Earth's Glacial Record. Cambridge University Press, pp. 1-28.

Farquhar, J., Bao, H., Thiemens, M., 2000. Atmospheric Influence of Earth's Earliest Sulfur Cycle. Science 289: 756-758.

Farquhar, J., Zerkle, A.L., Bekker, A., 2011. Geological constraints on the origin of oxygenic photosynthesis. Photosynth. Res. 107: 11-36.

Farrenkopf, A.M. and Luther III, G.W., 2002. Iodine chemistry reflects productivity and denitrification in the Arabian Sea: evidence for flux of dissolved species from sediments of western India into the OMZ. Deep Sea Res. Part II Top. Stud. Oceanogr. 49: 2303-2318.

Frausto da Silva, J.J.R., Williams, R.J., 2001. The biological chemistry of the elements: The inorganic chemistry of life. 2nd ed., Oxford University Press, Oxford, United Kingdom. p. 1- 575.

Feely, R.A., Trefry, J.H., Massoth, G.J., Metz, S., 1991. A comparison of the scavenging of phosphorus and arsenic from seawater by hydrothermal iron oxyhydroxides in the Atlantic and Pacific Oceans. Deep Sea Res. A 38: 617-623.

Feely, R.A., Trefry, J.H., Lebon, G.T., German, C.R., 1998. The relationship between $\mathrm{P} / \mathrm{Fe}$ and $\mathrm{V} / \mathrm{Fe}$ ratios in hydrothermal precipitates and dissolved phosphate in seawater. Geophys. Res. Lett. 25: 2253-2256.

Fedonkin, M.A., 2003. The origin of the Metazoa in the light of the Proterozoic fossil record. Paleontol. Res. 7: 9-41.

Fein, J. B., Daughney, C. J., Yee, N., Davis, T. A., 1997. A chemical equilibrium model for metal adsorption onto bacterial surfaces. Geochim. Cosmochim. Acta 61: 33193328.

Fein, J. B., Boily, J. -F., Yee, N., Gorman-Lewis, D., Turner, B. F., 2005. Potentiometric titrations of Bacillus subtilis cells to low $\mathrm{pH}$ and a comparison of modeling approaches. Geochim. Cosmochim. Acta 69: 1123-1132.

Frei, R., Gaucher, C., Poulton, S.W., Canfield, D.E., 2009. Fluctuations in Precambrian atmospheric oxygenation recorded by chromium isotopes. Nature 461: 250-253.

French, K.L., Hallmann, C., Hope, J.M., Schoon, P.L., Zumberge, J.A., Hoshino, Y., Peters, C.A., George, S.C., Love, G.D., Brocks, J.J., Buick, R., Summons, R.E., 2015. Reappraisal of hydrocarbon biomarkers in Archean rocks. Proc. Natl. Acad. Sci. USA 112: 5915-5920.

Frierdich, A.J., Luo, Y.L., Catalano, J.G., 2011. Trace element cycling through iron oxide minerals during redox driven dynamic recrystallization. Geology 39: 1083-1086.

Frierdich, A.J., Catalano, J.G., 2012. Controls on Fe(II)-Activated Trace Element Release from Goethite and Hematite. Environ. Sci. Tech. 46: 1519-1526.

Frierdich, A.J., Scherer, M.M., Bachman, J.E., Englehard, M.H., Rapponotti, B.W., Catalano, J.G., 2012. Inhibition of Trace Element Release During Fe(II)-Activated Recrystallization of Al-, Cr-, and Sn-Substituted Goethite and Hematite. Environ. Sci. Tech. 46: 10031-10039. 
Frost, C.D., von Blanckenburg, F., Schoenberg, R., Frost, B.R., Swapp, S.M., 2007. Preservation of $\mathrm{Fe}$ isotope heterogeneities during diagenesis and metamorphism of banded iron formation. Contrib. Mineral. Petrol. 153: 211-235.

Furnes, H., Banerjee, N.R., Muehlenbachs, K., Staudigel, H., de Wit, M., 2004. Early Life Recorded in Archean Pillow Lavas. Science 304: 578-581.

Fuse, H., Takimura, O., Yamaoka, Y., 1989. Effects of iodide and iodate ions on marine phytoplankton. In: Okaichi, T., Anderson, D., Nemoto, T. (eds) Red tides: biology, environmental science and toxicology. Elsevier, Amsterdam, p. 229-232.

Gallagher, M., Turner, E.C., Kamber, B.S., 2015. In situ trace metal analysis of Neoarchaean-Ordovician shallow-marine microbial-carbonate-hosted pyrites. Geobiology 13: 316-339.

Garcia-Ruiz, J.M., Hyde, S.T., Carnerup, A.M., Christy, A.G., Van Kranendonk, M.J., Welham, N.J., 2003. Self-Assembled Silica-Carbonate Structures and Detection of Ancient Microfossils. Science 302: 1194-1197.

Gellatly, A.M., Lyons, T.W., 2005. Trace sulfate in mid-Proterozoic carbonates and the sulfur isotope record of biospheric evolution. Geochim. Cosmochim. Acta 69: 3813-3829.

Gill, B.C., Lyons, T.W., Slatzman, M.R., 2007. Parallel, high-resolution carbon and sulfur isotope records for the evolving Paleozoic marine sulfure reservoir. Palaeogeogr. Paleoclimatol. Palaeoecol. 256: 156-173.

Gill, B.C., Lyons, T.W., Frank, T.D., 2008. Behavior of carbonate-associated sulfate during meteoric diagenesis and implications for the sulfur isotope paleoproxy. Geochim. Cosmochim. Acta: 72: 4699-4711.

Gill, B.C., Lyons, T.W., Young, S.E., Kump, L.R., Knoll, A.H., Slatzman, M.R., 2011. Geochemical evidence for widespread euxinia in the Later Cambrain ocean. Nature 469: 80-83.

Gingras, M.K., Hagadorn, J.W., Seilacher, A., Lalonde, S., Pecoits, E., Petrash, D., Konhauser, K.O., 2011. Possible evolution of mobile animals in association with microbial mats. Nat. Geosci. 4: 372-375.

Glass, J., Orphan, V.J., 2012. Trace metal requirements for microbial enzymes involved in the production and consumption of methane and nitrous oxide. Front. Microbiol. 3: $1-20$.

Glass, J.B., Wolfe-Simon, F., Anbar, A.D., 2009. Coevolution of metal availability and nitrogen assimilation in cyanobacteria and algae. Geobiology 7: 100-123.

Goldberg, S., Criscenti, L. J., 2007 Modeling adsorption of metals and metalloids by soil components. In: Biophysico-Chemical Processes of Heavy Metals and Metalloids in Soil Environments, A. Violante, P. M. Huang, G. M. Gadd, Eds., pp. 215-264.

Gordon, G.W., Lyons, T.W., Arnold, G.L., Roe, J., Sageman, B.B., and Anbar, A.D., 2009. When do black shales tell molybdenum isotope tales? Geology 37: 535-538.

Gregory, D., Meffre, S., Large, R., 2014. Comparison of metal enrichment in pyrite framboids from a metal-enriched and metal-poor estuary. Am. Mineral. 99: 633644.

Grosch, E.G., McLoughlin, N., 2014. Reassessing the biogenicity of Earth's oldest trace fossil with implications for biosignatures in the search for early life. Proc. Natl. Acad. Sci. USA 111: 8380-8385. 
Grotzinger, J.P., Knoll, A.H., 1999. Stromatolites in Precambrian Carbonates: Evolutionary Mileposts or Environmental Dipsticks? Annu. Rev. Earth Planet. Sci. 27: 313-358.

Gueguen, B., Reinhard, C.T., Algeo, T.J., Peterson, L.C., Nielsen, S.G., Wang, X., Rowe, H., Planavsky, N.J., 2016. The chromium isotope composition of reducing and oxic marine sediments. Geochim. Cosmochim. Acta 184: 1-19.

Guilbald, R., Poulton, S.W., Butterfield, N.J., Zhu, M., Shields-Zhou, G.A., 2015. A global transition to ferruginous conditions in the early Neoproterozoic oceans. Nat. Geosci. 8: 466-470.

Guo, Q., Strauss, H., Kaufman, A.J., Shröder, S., Gutzmer, J., Wing, B., Baker, M.A., Bekker, Z., Jin, Q., Kim, S.-T., Farquhar, J., 2009. Reconstructing Earth's surface oxidation across the Archean-Proterozoic transition. Geology 37: 399-402.

Hardisty, D.S., Lu, Z., Planavksy, N.J., Bekker, A., Philippot, P., Zhou, Xi., Lyons, T.W., 2014. An iodine record of Paleoproterozoic surface ocean oxygenation. Geology 42: 619-622.

Hatfield, D.L., Gladyshev, V.N., 2002. How Selenium Has Altered Our Understanding of the Genetic Code. Mol. Cell. Biol. 22: 3565-3576.

Haugaard, R., Frei, R., Stendal, H., Konhauser, K., 2013. Petrology and geochemistry of the $\sim 2.9 \mathrm{Ga}$ Itilliarsuk banded iron formation and associated supracrustal rocks, West Greenland: Source characteristics and depositional environment. Precambrian Res. 22: 150-176.

Haugaard, R., Pecoits, E., Lalonde, S., Rouxel, O., Konhauser, K., 2016. The Joffre banded iron formation, Hamersley Group, Western Australia: Assessing the palaeoenvironment through detailed petrology and chemostratigraphy. Precambrian Res. 273: 12-37.

Hausinger, R.P., 1987. Nickel Utilization by Microorganisms. Microbiol. Rev. 51: 22-42.

Helz, G.R., Miller, C.V., Charnock, J.M., Mosselmans, J.F.W., Pattrick, R.A.D., Garner, C.D., Vaughan, D.J., 1996. Mechanism of molybdenum removal from the sea and its concentration in black shales: EXAFS evidence. Geochim. Cosmochim. Acta 60: 3631-3642.

Helz, G.R., Bura-Nakić, E., Mikac, N., Ciglenečki, 2011. New model for molybdenum behavior in euxinic waters. Chem. Geol. 284: 323-332.

Heubeck, C., 2009. An early ecosystem of Archean tidal microbial mats (Moodies Group, South Africa, ca. $3.2 \mathrm{Ga}$ ). Geology 37: 931-934.

Hider, R.C., 1984. Siderophore mediated absorption of iron. Structure and Bonding 58: 25-87.

Hofmann, H.J., Grey, K., Hickman, A.H., Thorpe, R.I., 1999. Origin of 3.45 Ga coniform stromatolites in Warrawoona Group, Western Australia. Geol. Soc. Am. Bull. 111: 1256-1262.

Hoffman, P.F., Kaufman, A.J., Halverson, G.P., Schrag, D.P., 1998. A Neoproterozoic Snowball Earth. Science 281: 1342-1346.

Holland, H.D., 2006. The oxygenation of the atmosphere and oceans. Philos. T. R. Soc. B 361: 903-915.

Horton, F., 2015. Did phosphorus derived from the weathering of large igneous provinces fertilize the Neoproterozoic ocean? Geochem. Geophy. Geosy. 16: 1723-1738. 
Isley, A.E., Abbott, D.H., 1999. Plume-related mafic volcanism and the deposition of banded iron formation. J. Geophys. Res. 104: 15461-15477.

James, H.L., 1954. Sedimentary facies of iron-formation. Econ. Geol. 49: 235-293.

Janssen, D.J., Conway, T.M., John, S.G., Christian, J.R., Kramer, D.I., Pedersen, T.F., Cullen, J.T., 2014. Undocumented water column sink for cadmium in open ocean oxygen-deficient zones. Proc. Natl. Acad. Sci. USA 111: 6888-6893.

Javaux, E.J., Knoll, A.H., and Walter, M.R., 2001, Morphological and ecological complexity in early eukaryotic ecosystems: Nature 412: 66-69.

Johnston, D.T., Poulton, S.W., Dehler, C., Porter, S., Husson, J., Canfield, D.E., Knoll, A.H., 2010. An emerging picture of Neoproterozoic ocean chemistry: Insights from the Chuar Group, Grand Canyon, USA. Earth Planet. Sci. Lett. 290: 64-73.

Johnson, J.E., Webb, S.M., Thomas, K., Ono, S., Kirschvink, J.L., Fischer, W.W., 2013. Manganese-oxidizing photosynthesis before the rise of cyanobacteria. Proc. Natl. Acad. Sci. USA 110: 11238-11243.

Johnson, T.M., 2004. A review of mass-dependent fractionation of selenium isotopes and implications for other heavy stable isotopes. Chem. Geol. 204: 201-214.

Johnson, T.M., Bullen, T.D., 2004. Mass-dependent fractionation of selenium and chromium isotopes in low-temperature environments. Rev. Mineral. Geochem. 55: 289-317.

Jones, C. Nomosatryo, S., Crowe, S.A., Bjerrum, C.J., Canfield, D.E., 2015. Iron oxides, divalent cations, silica, and the early earth phosphorus crisis. Geology 43: 135-138.

Kah, L.C., Lyons, T.W., and Frank, T.D. (2004) Low marine sulphate and protracted oxygenation of the Proterozoic biosphere. Nature 431: 834-838.

Kasting, J.F., 2013. What caused the rise of atmospheric O2? Chem. Geol. 362: 13-25.

Kato, Y., Yamaguchi, K.E., Ohmoto, H., 2006. Rare earth elements in Precambrian banded iron formations: Secular changes of $\mathrm{Ce}$ and $\mathrm{Eu}$ anomalies and evolution of atmospheric oxygen, in: Rare Earth Elements in Precambrian Banded Iron Formations: Secular Changes of $\mathrm{Ce}$ and $\mathrm{Eu}$ Anomalies and Evolution of Atmospheric Oxygen. Geological Society of America, pp. 269-289.

Kendall, B., Creaser, R., Gordon, G.W., Anbar, A.D., 2009. Re-Os and Mo isotope systematics of black shales from the Middle Proterozoic Velkerri and Wollogorang Formations, McArthur Basin, northern Australia. Geochim. Cosmochim. Acta 73: 2534-2558.

Kendall, B., Reinhard, C.T., Lyons T.W., Kaufman, A.J., Poulton, S.W., Anbar, A.D., 2010. Pervasive oxygenation along late Archaean ocean margins. Nat. Geosci. 3: 647-652.

Kendall, B., Gordon, G.W., Poulton, S.W., Anbar, A.D., 2011. Molybdenum isotope constraints on the extent of late Paleoproterozoic ocean euxinia. Earth Planet. Sci. Lett. 307: 450-460.

Kendall, B., Anbar, A.D., Kappler, A., Konhauser, K.O., 2012. The Global Iron Cycle. In Knoll, A.H., Canfield, D.E., Konhauser, K.O., Fundamentals of Geobiology. John Wiley \& Son's, Oxford, UK. pp. 65-92.

Kendall, B., Brennecka, G.A., Weyer, S., Anbar, A.D., 2013. Uranium isotope fractionation suggests oxidative uranium mobilization at $2.50 \mathrm{Ga}$. Chem. Geol. 362 : $105-114$. 
Kendall, B., Komiya, T., Lyons, T.W., Bates, S.M., Gordon, G.W., Romaniello, S.J., Jiang, G., Creaser, R.A., Xiao, S., McFadden, K., Sawaki, Y., Tahata, M., Shu, D., Han, J., Li, Y., Chu, X, Anbar, A.D., 2015a. Uranium and molybdenum isotope evidence for an episode of widespread ocean oxygenation during the late Ediacaran Period. Geochim. Cosmochim. Acta 156: 173-193.

Kendall, B., Creaser, R.A., Reinhard, C.T., Lyons, T.W., Anbar, A.D., 2015b. Transient episodes of mild environmental oxygenation and oxidative continental weathering during the late Archean. Science Advances 1, e1500777-e1500777.

Kennedy, H.A., Elderfield, H., 1987. Iodine diagenesis in pelagic deep-sea sediments. Geochim. Cosmochim. Acta, 51: 2489-2504.

Kim, M.-J., Lee, B.C., Hwang, K.Y., Gladyshev, V.N., Kim, H.-Y., 2015. Selenium utilization in thioredoxin and catalytic advantage provided by selenocysteine. Biochem. Biophys. Res. Commun. 461: 648-652.

Kishida, K., Sohrin, Y., Okamura, K., Ishibashi, J., 2004. Tungsten enriched in submarine hydrothermal fluids. Earth Planet. Sci. Lett. 222: 819-827.

Kisker, C., Schindelin, H., Rees, D.C., 1997. Molybdenum-Cofactor-Containing Enzymes: Structure and Mechanism. Annu. Rev. Biochem. 66: 233-267.

Klein, C., 2005. Some Precambrian banded iron-formations (BIFs) from around the world: Their age, geologic setting, mineralogy, metamorphism, geochemistry and origin. Am. Mineral. 90: 1473-1499.

Knauth, L.P., Lowe, D.R., 2003. High Archean climatic temperature inferred from oxygen isotope geochemistry of cherts in the $3.5 \mathrm{Ga}$ Swaziland Supergroup, South Africa. Geol. Soc. Am. Bull. 115: 566-580.

Knauth, L.P., 2005. Temperature and salinity history of the Precambrian ocean: implications for the course of microbial evolution. Palaeogeogr. Palaeocl. 219: 5369.

Knoll, A.H., 2014. Paleobiological Perspectives on Early Eukaryotic Evolution. Cold Spring Harb. Perspect. Biol. 6: 1-14.

Knoll, A.H., Carroll, S.B., 1999. Early Animal Evolution: Emerging Views from Comparative Biology and Geology. Science 284: 2129-2137.

Knoll, A.H., Wörndle, S., Kah, L.C., 2013. Covariance of microfossil assemblages and microbialite textures across an upper Mesoproterozoic carbonate platform. Palaios, 28(7): 453-470.

Kobayashi, M., Shimizu, S., 1999. Cobalt proteins. Eur. J. Biochem. 261: 1-9.

Koeppenkastrop, D., De Carlo, E.H., 1992. Sorption of rare-earth elements from seawater onto synthetic mineral particles: An experimental approach. Chem. Geol. 95: 251263.

Konhauser. K.O., Lalonde S.V., Amskold, L.A., Holland, H.D., 2007. Was There Really an Archean Phosphate Crisis? Science 315: 1234.

Konhauser, K.O., Pecoits, E., Lalonde, S.V., Papineau, D., Nisbet, E.G., Barley, M.E., Arndt, N.T., Zahnle, K., Kamber, B.S., 2009. Oceanic nickel depletion and a methanogen famine before the Great Oxidation Event. Nature 458: 750-753.

Konhauser, K.O., Lalonde, S.V., Planavsky, N.J., Pecoits, E., Lyons, T.W., Mojzsis, S.J., Rouxel, O.J., Barley, M.E., Rosière, C., Fralick, P.W., Kump, L.R., Bekker, A., 2011. Aerobic bacterial pyrite oxidation and acid rock drainage during the Great Oxidation Event. Nature 478: 369-373. 
Konhauser, K.O., Robbins, L.J., Pecoits, E., Peacock, C.L., Kappler, A., Lalonde, S.V., 2015. The Archean nickel famine revisited. Astrobiology 15: 804-815.

Koretsky, C., 2000. The significance of surface complexation reactions in hydrologic systems: a geochemist's perspective. Journal of Hydrology 230: 127-171.

Krapež, B., Barley, M.E., Pickard, A.L., 2003. Hydrothermal and resedimented origins of the precursor sediments to banded iron formation: sedimentological evidence from the Early Palaeoproterozoic Brockman Supersequence of Western Australia. Sedimentology 50: 979-1011.

Kunzmann, M., Halverson, G.P., Sossi, P.A., Raub, T.D., Payne, J.L., Kirby, J., 2013. Zn isotope evidence for immediate resumption of primary productivity after snowball Earth. Geology 41: 27-30.

Küpper, F.C., Schweigert, N., Ar Gall, E., Legendre, J.-M., Vilter, H., Kloareg, B., 1988. Iodine uptake in Laminariales involves extracellular, haloperoxidase-mediated oxidation of iodide. Planta 207: 163-171.

L'vov, N.P., Nosikov, A.N., Antipov, A.N., 2002. Tungsten-Containing Enzymes. Biokhimiia 67: 196-200.

Lalonde, S.V., Konhauser, K.O., 2015. Benthic perspective on Earth's oldest evidence for oxygenic photosynthesis. Proc. Natl. Acad. Sci. USA 112: 995-1000.

Lane, T.W., Morel, F.M.M., 2000. A biological function for cadmium in marine diatoms. Proc. Natl. Acad. Sci. USA 97: 4627-4631.

Landing, W.M., Burnett, W.C., Lyons, W.B., Orem, W.H., 1991. Nutrient Cycling and the Biogeochemistry of Manganese, Iron, and Zinc in Jellyfish Lake, Palau. Limnol. Oceanogr. 36: 515-525.

Large, R.R., Danyushevsky, L., Hollit, C., Maslennikov, V., Meffre, S., Gilbert, S., Bull, S., Scott, R., Emsbo, P., Thomas, H., Singh, B., Foster, J., 2009. Gold and trace element zonation in pyrite using a laser imaging technique: implications for the timing of gold in orogenic and carlin-style sediment-hosted deposits. Econ. Geol. 104: 635-668.

Large, R.R., Halpin, J.A., Danyushevsky, L.V., Maslennikov, V.V., Bull, S.W., Long, J.A., Gregory, D.D., Lounejeva, E., Lyons, T.W., Sack, P.J., McGoldrick, P.J., Claver, C.R., 2014. Trace element content of sedimentary pyrite as a new proxy for deep-time ocean-atmosphere evolution. Earth Planet. Sci. Lett. 389: 209-220.

Large, R.R., Halpin, J.A., Lounejeva, E., Danyushevsky, L.V., Maslennikov, V.V., Gregory, D., Sack, P.J., Haines, P.W., Long, J.A., Makoundi, C., Stepanov, S., 2015. Cycles of nutrient trace elements in the Phanerozoic ocean. Gondwana Res. 28: 1282-1293.

Lepland, A., Van Zuilen, M.A., Philippot, P., 2011. Fluid-deposited graphite and its geobiological implications in early Archean gneiss from Akilia, Greenland. Geobiology 9: 2-9.

Li, C., Love, G.D., Lyons, T.W., Fike, D.A., Sessions, A.L., Chu, X., 2010. A Stratified Redox Model for the Ediacaran Ocean. Science 328: 80-83.

Li, C., Planavsky, N.J., Love, G.D., Reinhard, C.T., Hardisty, D., Feng, L., Bates, S.M., Huang, J., Zhang, Q., Chu, X., Lyons, T.W., 2015. Marine redox conditions in the middle Proterozoic ocean and isotopic constraints on authigenic carbonate formation: Insights from the Chuanlinggou Formation, Yanshan Basin, North China. Geochim. Cosmochim. Acta 150: 90-105. 
Li, Y.L., Konhauser, K.O., Cole, D.R., Phelps, T.J., 2011. Mineral ecophysiological data provide growing evidence for microbial activity in banded-iron formations. Geology 39: 707-710.

Lipscomb, W.N., Sträter, N., 1996. Recent Advances in Zinc Enzymology. Chem. Rev. 96: 2375-2433.

Liu, Y., Alessi, D.S., Owttrim, G.W., Petrash, D.A., Mloszewska, A.M., Lalonde, S.V., Martinez, R.E., Zhou, Q., Konhauser, K.O., 2015. Cell surface reactivity of Synechococcus sp. PCC 7002: Implications for metal sorption from seawater. Geochim. Cosmochim. Acta 169: 30-44.

Lohan, M.C., Crawford, D.W., Purdie, D.A., Statham, P.J., 2005. Iron and zinc enrichments in the northeastern subarctic Pacific: Ligand production and zinc availability in response to phytoplankton growth. Limnol. Oceanogr. 50: 14271437.

Long, J.A., Large, R.R., Lee, M.S.Y., Benton, M.J., Danyushevsky, L.V., Chiappe, L.M., Halpin, J.A., Cantrill, D., Lottermoser, B., 2016. Severe selenium depletion in the Phanerozoic oceans as a factor in three global mass extinction events. Gondwana Res. 36: 209-218.Love, G., Grosjean, E., Stalvies, C., Fike, D., Grotzinger, J., Bradley, A., Kelly, A., Bhatia, M., Meredith, W., Snape, C., 2009. Fossil steroids record the appearance of Demospongiae during the Cryogenian period. Nature 457: 718-721.

Lovley, D.R., Phillips, E.J.P., Gorby, Y.A., Landa, E.R., 1991. Microbial reduction of uranium. Nature 350: 413-416.

Lowe, D.R., 1994. Abiological origin of described stromatolites older than $3.2 \mathrm{Ga}$. Geology 22: 387-390.

Lu, Z., Jenkyns, H.C., Rickaby, R.E., 2010. Iodine to calcium ratios in marine carbonate as a paleo-redox proxy during oceanic anoxic events. Geology, 38: 1107-1110.

Luther III, G.W., Campbell, T., 1991. Iodine speciation in the water column of the Black Sea. Deep Sea Res. A 38: S875-S882.

Lyons, T.W., Berner, R.A., 1992. Carbon-sulfur-iron systematics of the uppermost deepwater sediments of the Black Sea. Chem. Geol. 99: 1-27.

Lyons, T.W., Werne, J.P., Hollander, D.J., Murray, R.W., 2003. Contrasting sulfur geochemistry and $\mathrm{Fe} / \mathrm{Al}$ and $\mathrm{Mo} / \mathrm{Al}$ ratios across the last oxic-to-anoxic transition in the Cariaco Basin, Venezuela. Chem. Geol. 195: 131-157.

Lyons, T.W., Walter, L.M., Gellatly, A.M., Martini, A.M., Blake, R.E., 2004. Sites of anomalous organic remineralization in the carbonate sediments of South Florida, USA: the sulfur cycle and carbonate-associated sulfate. Geol. S. Am. S. 379: 161176.

Lyons, T.W., Gellatly, A.M., McGoldrick, P.J., Kah, L.C., 2006. Proterozoic sedimentary exhalative (SEDEX) deposits and links to evolving global ocean chemistry. In Kesler, S.E., and Ohmoto, H., eds., Evolution of Early Earth's Atmosphere, Hydrosphere, and Biosphere-Constraints from Ore Deposits. Geological Society of America Memoir 198:169-184.

Lyons, T.W., Anbar, A.D., Severmann, S., Scott, C., Gill, B.C., 2009. Tracking Euxinia in the Ancient Ocean: A Multiproxy Perspective and Proterozoic Case Study. Earth-Sci. Rev. 37: 507-534. 
Lyons, T.W., Reinhard, C.T., Planavsky, N.J., 2014a. The rise of oxygen in Earth's early ocean and atmosphere. Nature 506: 307-315.

Lyons, T.W., Reinhard, C.T., Planavsky, N.J., 2014b. Evolution: A Fixed-Nitrogen Fix in the Early Ocean? Curr. Biol. 24: R276-R278.

Maliva, R.G., Knoll, A.H., Simonson, B.M., 2005. Secular change in the Precambrian silica cycle: Insights from chert petrology. Geol. Soc. Am. Bull. 117: 835-845.

Marin-Carbonne, J., Robert, F., Chaussidon, M., 2014. The silicon and oxygen isotope compositions of Precambrian cherts: A record of oceanic paleo-temperatures? Precambrian Res. 247: 223-234.

Marsh, E.N.G., 1999. Coenzyme B 12 (cobalamin)-dependent enzymes. Essays Biochem. 34: $139-154$.

Martin, J.H., Fitzwater, S.E., 1988. Iron deficiency limits phytoplankton growth in the north-east Pacific subarctic. Nature 331: 341-343.

Martinez, R.E., Konhauser, K.O., Paunova, N., Wu, W., Alessi, D.S., Kappler, A., 2016. Surface reactivity of the anaerobic photoferrotrophic Fe(II)-oxidizing bacterium Rhodovulum iodosum: Implications for trace metal budgets in ancient oceans and banded iron formation. Chem. Geol.: in press.

März, C., Poulton, S.W., Beckmann, B., Küster, K., Wagner, T., Kasten, S., 2008. Redox sensitivity of $\mathrm{P}$ cycling during marine black shale formation: Dynamic of sulfidic and anoxic, non-sulfidic bottom waters. Geochim. Cosmochim. Acta 72: 37033717.

McKeegan, K.D., Kudryavtsev, A.B., Schopf, J.W., 2007. Raman and ion microscopic imagery from older than 3830 Ma Akilia supracrustal rocks, west Greenland. Geology 35: 591-594.

Mills, D.B., Ward, L.M., Jones, C., Sweeten, B., Forth, M., Treusch, A.H., Canfield, D.E., 2014. Oxygen requirements of the earliest animals. Proc. Natl. Acad. Sci. USA 111: 4168-4172.

Mitchell, K., Mason, P.R.D., Van Cappellen, P., Johnson, T.M., Gill, B.C., Owens, J.D., Diaz, J., Ingall, E.D., Reichart, G.-J., Lyons, T.W., 2012. Selenium as paleooceanographic proxy: A first assessment. Geochim. Cosmochim. Acta 89: 302-317.

Moczydłowska, M., Landing, E., Zang, W., Palacios, T., 2011. Proterozoic phytoplankton and timing of chlorophyte algae origins. Palaeontology 54: 721-733.

Mojzsis, S.J., Arrhenius, G., McKeegan, K.D., Harrison, T.M., Nutman, A.P., Friend, C.R.L., 1996. Evidence for life on Earth before 3,800 million years ago. Science 384: 55-59.

Moore, C.M., Mills, M.M., Arrigo, K.R., Berman-Frank, I., Bopp, L., Boyd, P.W., Galbraith, E.D., Geider, R.J., Guieu, C., Jaccard, S.L., Jickells, T.D., La Roche, J., Lenton, T.M., Mahowald, N.M., Marañón, E., Marinov, I., Moore, J.K., Nakatsuka, T., Oschlies, A., Saito, M.A., Thingstad, T.F., Tsuda, A., Ulloa, O., 2013. Processes and patterns of oceanic nutrient limitation. Nat. Geosci. 6: 701-710.

Morel, F.M.M., Reinfelder, J.R., Roberts, S.B., Chamberlain, C.P., Lee, J.G., Yee, D., 1994. Zinc and carbon co-limitation of marine phytoplankton. Nature 369: 740-742.

Morel, F.M.M., Price, N.M., 2003. The Biogeochemical Cycles of Trace Metals in the Oceans. Science 300: 944-947.

Morel, F.M.M., 2008. The co-evolution of phytoplankton and trace element cycles in the oceans. Geobiology 6: 318-324. 
Morford, J.L., Emerson, S., 1999. The geochemistry of redox sensitive trace elements in sediments. Geochem. Cosmochim. Acta 63: 1735-1750.

Morford, J.L., Emerson, S.R., Breckel, E.J., Kim, S.H., 2005. Diagenesis of oxyanions (V, U, Re, and Mo) in pore waters and sediments from a continental margin. Geochim. Cosmochim. Acta 69: 5021-5032.

Morris, R.C., 1993. Genetic modeling for banded iron-formation of the Hamersley Group, Pilbara Craton, Western Australia. Precambrian Res. 60: 243-286.

Mücke, A., Farshad, F., 2005. Whole-rock and mineralogical composition of Phanerozoic ooidal ironstones: Comparison and differentiation of types and subtypes. Ore Geol. Rev. 26, 227-262.

Mukherjee, I., Large, R.R., 2016. Pyrite trace element chemistry of the Velkerri Formation, Roper Group, McArthur Basin: Evidence for atmospheric oxygenation during the Boring Billion. Precambrian Res. 281: 1-37.

Muramatsu, Y., Hans Wedepohl, K., 1998. The distribution of iodine in the earth's crust. Chem. Geol., 147: 201-216.

Neilands, J.B., 1989. Siderophore systems of bacteria and fungi. In Doyle, R.J. (ed), Metal Ions and Bacteria. John Wiley \& Sons, New York, pp. 141-163.

Neubert, N., Nägler, T.F., and Böttcher, M.E., 2008. Sulfidity controls molybdenum isotope fractionation into euxinic sediments: Evidence from the modern Black Sea. Geology 36: 775-778.

Noffke, N., 2009. The criteria for the biogenecity of microbially induced sedimentary structures (MISS) in Archean and younger, sandy deposits. Earth-Sci. Rev. 96: 173180.

Noffke, N., Christian, D., Wacey, D., Hazen, R.M., 2013. Microbially Induced Sedimentary Structures Recording an Ancient Ecosystem in the ca. 3.48 BillionYear-Old Dresser Formation, Pilbara, Western Australia. Astrobiology 13: 11031124.

Nursall, J.R., 1959. Oxygen as a prerequisite to the origin of the metazoa. Nature 183: 1170-1172.

Nutman, A.P., Bennett, V.C., Friend, C.R.L., Van Kranendonk, M.J., Chivas, A.R., 2016. Rapid emergence of life shown by discovery of 3,700-million-year-old microbial structures. Nature 537: 535-538.

Ohnemueller, F., Prave, A. R., Fallick, A. E., Kasemann, S. A., 2014. Ocean acidification in the aftermath of the Marinoan glaciation. Geology 42: 1103-1106.

Olson, S.L., Kump, L.R., Kasting, J.F., 2013. Quantifying the areal extent and dissolved oxygen concentrations of Archean oxygen oases. Chem. Geol. 362: 35-43.

Palenik, B., Grimwood, J., Aerts, A., Rouzé, P., Salamov, A., Putnam, N., Dupont, C., Jorgensen, R., Derelle, E., Rombauts, S., Zhou, K., Otillar, R., Merchant, S.S., Podell, S., Gaasterland, T., Napoli, C., Gendler, K., Manuell, A., Tai, V., Vallon, O., Piganeau, G., Jancek, S., Heijde, M., Jabbari, K., Bowler, C., Lohr, M., Robbens, S., Werner, G., Dubchak, I., Pazour, G.J., Ren, Q., Paulsen, I., Delwiche, C., Schmutz, J., Rokhsar, D., Van de Peer, Y., Moreau, H., Grigoriev, I.V., 2007. The tiny eukaryote Ostreococcus provides genomic insights into the paradox of plankton speciation. Proc. Natl. Acad. Sci. USA 104: 7705-7710. 
Partin, C.A., Lalonde, S.V., Planavksy, N.J., Bekker, A., Rouxel, O.J., Lyons, T.W., Konhauser, K.O., 2013a. Uranium in iron formations and the rise of atmospheric oxygen. Chem. Geol. 362: 82-90.

Partin, C.A., Bekker, A., Planavsky, N.J., Scott, C.T., Gill, B.C., Li, C., Podkovyrov, V., Maslov, A., Konhauser, K.O., Lalonde, S.V., Love, G.D., Poulton, S.W., Lyons, T.W., 2013b. Large-scale fluctuations in Precambrian atmospheric and oceanic oxygen levels from the record of $U$ in shales. Earth Planet. Sci. Lett. 369-370: 284293.

Pavlov, A.A., Kasting, J.F., 2002. Mass-Independent Fractionation of Sulfur Isotopes in Archean Sediments: Strong Evidence for an Anoxic Archean Atmosphere. Astrobiology 2: 27-41.

Pearson, P. N., Palmer, M. R., 1999. Middle Eocene seawater $\mathrm{pH}$ and atmospheric carbon dioxide concentrations. Science 284: 1824-1826.

Pecoits, E., Gingras, M.E., Barley, M.E., Kappler, A., Posth, N.R., Konhauser, K.O., 2009. Petrography and geochemistry of the Dales Gorge banded iron formation: Paragenetic sequence, source and implications for palaeo-ocean chemistry. Precambrian Res. 172: 163-187.

Pecoits, E., Konhauser, K.O., Aubet, N., Heaman, L.M., Veroslavsky, G., Stern, R., Gingras, M.K., 2012. Bilaterian burrows and grazing behavior at $>585$ million years ago. Science, 336: 1693-1696.

Peers, G., Price, N.M., 2006. Copper-containing plastocyanin used for electron transport by an oceanic diatom. Nature 441: 341-344.

Planavsky, N., Bekker, A., Rouxel, O.J., Kamber, B., Hofmann, A., Knudsen, A., Lyons, T.W., 2010a. Rare Earth Element and yttrium compositions of Archean and Paleoproterozoic Fe formations revisited: New perspectives on the significance and mechanisms of deposition. Geochim. Cosmochim. Acta 74: 6387-6405.

Planavsky, N.J., Rouxel, O.J., Bekker, A., Lalonde, S.V., Konhauser, K.O., Reinhard, C.T., Lyons, T.W., 2010b. The evolution of the marine phosphate reservoir. Nature 467: 1088-1090.

Planavksy, N.J., McGoldrick, P., Scott, C.T., Li, C., Reinhard, C.T., Kelly, A.E., Chu, X., Bekker, A., Love, G.D., Lyons, T.W., 2011. Widespread iron-rich conditions in the mid-Proterozoic ocean. Nature 477: 448-451.

Planavsky, N.J., Bekker, A., Hofmann, A., Owens, J.D., Lyons, T.W., 2012. Sulfur record of rising and falling marine oxygen and sulfate levels during the Lomagundi event. Proc. Natl. Acad. Sci. USA 109: 18300-18305.

Planavsky, N.J., Reinhard, C.T., Wang, X., Thomson, D., McGoldrick, P., Rainbird, R.H., Johnson, T., Fischer, W.W., Lyons, T.W., 2014a. Low Mid-Proterozoic atmospheric oxygen levels and the delayed rise of animals. Science 346: 635-638.

Planavsky, N.J., Asael, D., Hofmann, A., Reinhard, C.T., Lalonde, S.V., Knudsen, A., Wang, X., Ossa Ossa, F., Pecoits, E., Smith, A.J.B., Beukes, N.J., Bekker, A., Johnson, T.M., Konhauser, K.O., Lyons, T.W., Rouxel, O.J., 2014b. Evidence for oxygenic photosynthesis half a billion years before the Great Oxidation Event. Nat. Geosci. 7: 283-286.

Planavsky, N.J., Cole, D.B., Reinhard, C.T., Diamond, C., Love, G.D., Luo, G., Zhang, S., Konhauser, K.O., Lyons, T.W., 2016. No evidence for high atmospheric oxygen levels 1,400 million years ago. Proc. Natl. Acad. of Sci. USA 113: E2550-E2551. 
Pogge von Strandmann, P.A.E., Coath, C.D., Catling, D.C., Poulton, S.W., Elliot, T., 2014. Analysis of mass dependent and mass independent selenium isotope variability in black shales. J. Anal. At. Spectrom. 29: 1648-1659.

Pogge von Strandmann, P.A.E., Stüeken, E.E., Elliot, T., Poulton, S.W., Dehler, C.M., Canfield, D.E., Catling, D.C., 2015. Selenium isotope evidence for progressive oxidation of the Neoproterozoic biosphere. Nat. Commun. 6: 10157.

Pons, M.L., Fujii, T., Rosing, M., Quitté, G., Télouk, P., Albarède, F., 2013. A Zn isotope perspective on the rise of continents. Geobiology 11: 201-214.

Posth, N.R., Canfield, D.E., Kappler, A., 2014. Biogenic Fe(III) minerals: From formation to diagenesis and preservation in the rock record. Earth-Sci. Rev. 135: 103-121.

Poulton, S.W., Fralick, P.W., Canfield, D.E., 2004. The transition to a sulphidic ocean $\sim 1.84$ billion years ago. Nature 431: 173-177.

Poulton, S.W., Canfield, D.E., 2005. Development of a sequential extraction procedure for iron: implications for iron partitioning in continentally derived particulates. Chem. Geol. 214: 209-221.

Poulton, S.W., Fralick, P.W., Canfield, D.E., 2010. Spatial variability in oceanic redox structure 1.8 billion years ago. Nat. Geosci. 3: 486-490.

Poulton, S.W., Canfield, D.E., 2011. Ferruginous Conditions: A Dominant Feature of the Ocean through Earth's History. Elements 7: 107-112.

Pushie, M.J., Cotelesage, J.J., George, G.N., 2014. Molybdenum and tungsten oxygen transferases - structural and functional diversity within a common active site motif. Metallomics 6: 15-24.

Ragsdale, S.W., Kumar, M., 1996. Nickel-Containing Carbon Monoxide Dehydrogenase/Acetyl-CoA Synthase. Chem. Rev. 96: 2515-2539.

Rasmussen, B., Fletcher, I.R., Brocks, J.J., Kilburn, M.R., 2008. Reassessing the first appearance of eukaryotes and cyanobacteria. Nature 455: 1101-1104.

Rasmussen, B., Fletcher, I.R., Bekker, A., Muhling, J.R., Gregory, C.J., Thorne, A.M., 2012. Deposition of 1.88-billion-year-old iron formations as a consequence of rapid crustal growth. Nature 484: 498-501.

Reinhard, C.T., Raiswell, R., Scott, C., Anbar, A.D., Lyons, T.W., 2009. A Late Archean Sulfidic Sea Stimulated by Early Oxidative Weathering of the Continents. Science 326: 713-716.

Reinhard, C.T., Planavsky, N.J., Lyons, T.W., 2013a. Long-term sedimentary recycling of rare sulphur isotope anomalies. Nature 497: 100-103.

Reinhard, C.T., Planavksy, N.J., Robbins, L.J., Partin, C.A., Gill, B.C., Lalonde, S.V., Bekker, A., Konhauser, K.O., Lyons, T.W., 2013b. Proterozoic ocean redox and biogeochemical stasis. Proc. Natl. Acad. Sci. USA 110: 5357-5362.

Reinhard, C.T., Planavsky, N.J., Wang, X., Fischer, W.W., Johnson, T.M., Lyons, T.M., 2014. The isotopic composition of authigenic chromium in anoxic marine sediments: A case study from the Cariaco Basin. Earth Planet. Sci. Lett. 407: 9-18.

Robbins, L.J., Lalonde, S.V., Saito, M.A., Planavsky, N.J., Mloszewska, A.M., Pecoits, E., Scott, C., Dupont, C.L., Kappler, A., Konhauser, K.O., 2013. Authigenic iron oxide proxies for marine zinc over geological time and implications for eukaryotic metallome evolution. Geobiology 11: 295-306. 
Robbins, L.J., Swanner, E.D., Lalonde, S.V., Eickhoff, M., Paranich, M.L., Reinhard, C.T., Peacock, C.L., Kappler, A., Konhauser, K.O., 2015. Limited Zn and Ni mobility during simulated Iron Formation diagenesis. Chem. Geol. 402: 30-39.

Robert, F., Chaussidon, M., 2006. A palaeotemperature curve for the Precambrian oceans based on silicon isotopes in cherts. Nature 443: 969-972.

Roberts, S., Lane, T., Morel, F.M.M., 1997. Carbonic anhydrase in the marine diatom Thalassiosira weissflogii (Bacillariophyceae). J. Phycol. 33: 845-850.

Rosing, M.T., 1999. ${ }^{13}$ C-Depleted Carbon Microparticles in >3700-Ma Sea-Floor Sedimentary Rocks from West Greenland. Science 283: 674-676.

Rosing, M.T., Frei, R., 2004. U-rich Archaean sea-floor sediments from Greenland indications of $>3700$ Ma oxygenic photosynthesis. Earth Planet. Sci. Lett. 217: 237244.

Rothman, D.H., Fournier, G.P., French, K.L., Alm, E.J., Boyle, E.A., Cao, C., Summons, R.E., 2014. Methanogenic burst in the end-Permian carbon cycle. Proc. Natl. Acad. Sci. USA 111: 5462-5467.

Rue, E.L., Smith, G.J., Cutter, G.A., Bruland, K.W., 1997. The response of trace element redox couples to suboxic conditions in the water column. Deep Sea Res. Part I Oceanogr. Res. Pap. 44: 113-134.

Sageman, B.B., Murphy, A.E., Werne, J.P., Ver Streten, C.A., Hollander, D.J., Lyons, T.W., 2003. A tale of shales: the relative roles of production, decomposition, and dilution in the accumulation of organic-rich strata, Middle-Upper Devonian, Appalachian basin. Chem. Geol. 195: 229-273.

Sahoo, S.K., Planavsky, N.J., Kendall, B., Wang, X., Shi, X., Scott, C., Anbar, A.D., Lyons, T.W., Jiang, G., 2012. Ocean oxygenation in the wake of the Marinoan glaciation. Nature 489: 546-549.

Sahoo, S.K., Planavsky, N.J., Jiang, G., Kendall, B., Owens, J.D., Wang, X., Shi, X., Anbar, A.D., Lyons, T.W., 2016. Oceanic oxygenation events in the anoxic Ediacaran ocean. Geobiology 14: 457-468.

Saito, M.A., Moffett, J.W., 2001. Complexation of cobalt by natural organic ligands in the Sargasso Sea as determined by a new high-sensitivity electrochemical cobalt speciation method suitable for open ocean work. Mar. Chem. 75: 49-68.

Saito, M.A., Moffett, J.W., Chisholm, S.E., Waterbury, J.B., 2002. Cobalt limitation and uptake in Prochlorococcus. Limnol. Oceanogr. 47: 1629-1636.

Saito, M.A., Sigman, D.M., Morel, F.M.M., 2003. The bioinorganic chemistry of the ancient ocean: the co-evolution of cyanobacterial metal requirements and biogeochemical cycles at the Archean-Proterozoic boundary? Inorg. Chim. Acta 356: 308-318.

Saito, M.A., Rocap, G., Moffett, J.W., 2005. Production of cobalt binding ligands in a Synechococcus feature at the Costa Rica upwelling dome. Limnol. Oceanogr. 50: 279-290.

Sánchez-Baracaldo, P., Ridgwell, A., Raven, J.A., 2014. A Neoproterozoic Transition in the Marine Nitrogen Cycle. Curr. Biol. 24: 652-657.

Sanford, W.E., Doughten, M.W., Coplen, T.B., Hunt, A.G., Bullen, T.D., 2013. Evidence for high salinity of Early Cretaceous sea water from the Chesapeake Bay crater. Nature 503: 252-256. 
Santoro, A.E., Dupont, C.L., Richter, R.A., Craig, M.T., Carini, P., McIlvin, M.R., Yang, Y., Orsi, W.D., Moran, D.M., Saito, M.A., 2015. Genomic and proteomic characterization of "Candidatus Nitrosopelagicus brevis": An ammonia-oxidizing archaeon from the open ocean. Proc. Natl. Acad. Sci. USA 112: 1173-1178.

Satkoski, A.M., Beukes, N.J., Li, W., Beard, B.L., Johnson, C.M., 2015. A redoxstratified ocean 3.2 billion years ago. Earth Planet. Sci. Lett. 430: 43-53.

Scheiderich, K., Amini, M., Holmden, C., Francois, R., 2015. Global variability of chromium isotopes in seawater demonstrated by Pacific, Atlantic, and Arctic Ocean samples. Earth Planet. Sci. Lett. 423: 87-97.

Schopf, J.W., Packer, B.M., 1987. Early Archean (3.3 to 3.5 billion-year-old) microfossils from Warrawoona Group, Australia. Science 237: 70-73.

Schopf, J.W., 1993. Microfossils of the Early Archean Apex Chert: new evidence of the antiquity of life. Science 260: 640-646.

Schopf, J.W., 2006. Fossil evidence of Archaean life. Philos. T. Roy. Soc. B. 361: 869885.

Schrag, D.P., Higgins, J.A., Macdonald, F.A., Johnston, D.T., 2013. Authigenic carbonate and the history of the global carbon cycle. Science: $339: 540-543$.

Scott, C., Lyons, T.W., Bekker, A., Shen, Y., Poulton, S.W., Chu, X., Anbar, A.D., 2008. Tracing the stepwise oxygenation of the Proterozoic ocean. Nature 452: 456-459.

Scott, C., Lyons, T.W., 2012. Contrasting molybdenum cycling and isotopic properties in euxinic versus non-euxinic sediments and sedimentary rocks: Refining the paleoproxies. Chem. Geol. 324-325: 19-27.

Scott, C., Planavsky, N.J., Dupont, C.L., Kendall, B., Gill, B.C., Robbins, L.J., Husband, K.F., Arnold, G.L., Wing, B.A., Poulton, S.W., Bekker, A., Anbar, A.D., Konhauser, K.O., Lyons, T.W., 2013. Bioavailability of zinc in marine systems through time. Nat. Geosci. 6: 125-128.

Sharp, Z., Draper, D., 2013. The chlorine abundance of Earth: Implications for a habitable planet. Earth Planet. Sci. Lett. 369: 71-77.

Siebert, C., Kramers, J.D., Meisel, T., Morel, P., Nägler, T.F., 2005. PGE, Re-OS, and Mo isotope systematics in Archean and early Proterozoic sedimentary systems as proxies for redox conditions of the early Earth. Geochim. Cosmochim. Acta 69: 1787-1801.

Siever, R., 1992. The silica cycle in the Precambrian. Geochim. Cosmochim. Acta 56: 3265-3272.

Simonson, B.M., 1985. Sedimentology of cherts in the Early Proterozoic Wishart Formation, Quebec-Newfoundland, Canada. Sedimentology 32: 23-40.

Simonson, B.M., Goode, A.D.T., 1989. First discovery of ferruginous chert arenites in the early Precambrian Hamersley Group of Western Australia. Geology 17: 269272.

Solomon, E.I., Sundaram, U.M., Machonkin, T.E., 1996. Multicopper oxidases and oxygenases. Chem. Rev. 96: 2563-2605.

Sperling, E.A., Halverson, G.P., Knoll, A.H., Macdonald, F.A. and Johnston, D.T., 2013. A basin redox transect at the dawn of animal life. Earth Planet. Sci. Lett. 371: 143155.

Sperling, E.A., Wolock, C.J., Morgan, A.S., Gill, B.C., Kunzmann, M., Halverson, G.P., Macdonald, F.A., Knoll, A.H., Johnston, D.T., 2015. Statistical analysis of iron 
geochemical data suggests limited late Proterozoic oxygenation. Nature 523: 451454.

Sposito, G., 1982. On the use of the Langmuir equation in the interpretation of "adsorption" phenomena. II. The "two-surface" Langmuir equation. Soil Sci. Soc. Am. J. 46: 1147-1152.

Stefurak, E.J.T., Lowe, D.R., Zentner, D., and Fischer, W.W., 2014. Primary silica granules - A new mode of Paleoarchean sedimentation. Geology 42: 283-286.

Stefurak, E.J.T., Lowe, D.R., Zentner, D., Fischer, W.W., 2015. Sedimentology and geochemistry of Archean silica granules. Geol. Soc. Am. Bull. 127: 1090-1107.

Steinhoefel, G., von Blanckenburg, F., Horn, I., Konhauser, K.O., Beukes, N.J., Gutzmer, J., 2010. Deciphering formation processes of banded iron formations from the Transvaal and the Hamersley successions by combined $\mathrm{Si}$ and $\mathrm{Fe}$ isotope analysis using UV femtosecond laser ablation. Geochim. Cosmochim. Acta 74: 2677-2696.

Stüeken, E.E., Buick, R., Guy, B.M., Koehler, C., 2015a. Isotopic evidence for nitrogen fixation by molybdenum-nitrogenase from 3.2 Gyr. Nature 520: 666-669.

Stüeken, E.E., Buick, R., Bekker, A., Catling, D., Foriel, J., Guy, B.M., Kah, L.C., Machel, H.G., Montañez, I.P., Poulton, S.W., 2015b. The evolution of the global selenium cycle: Secular trends in Se isotopes and abundances. Geochim. Cosmochim. Acta 162: 109-125.

Stüeken, E.E., Buick, R., Anbar, A.D., 2015c. Selenium isotopes support free $\mathrm{O}_{2}$ in the latest Archean. Geology 43: 259-262.

Stüeken, E.E., Foriel, J., Buick, R., Schoepfer, S.D., 2015d. Selenium isotope ratios, redox changes and biological productivity across the end-Permian mass extinction. Chem. Geol. 410: 28-39.

Stylo, M., Neubert, N., Wang, Y., Monga, N., Romaniello, S.J., Weyer, S., BernierLatmani, R., 2015. Uranium isotopes fingerprint biotic reduction. Proc. Natl. Acad. Sci. USA: 112, 5619-5624.

Sunda, W.G., Huntsman, S.A., 1995. Cobalt and zinc interreplacement in marine phytoplankton: Biological and geochemical implications. Limnol. Oceanogr. 40: 1404-1417.

Swanner, E.D., Bekker, A., Pecoits, E., Konhauser, K.O., Cates, N.L., Mojzsis, S.J., 2013. Geochemistry of pyrite from diamictites of the Boolgeeda Iron Formation, Western Australia with implications for the GOE and Paleoproterozoic ice ages. Chem. Geol. 362: 131-142.

Swanner, E.D., Planavsky, N.J., Lalonde, S.V., Robbins, L.J., Bekker, A., Rouxel, O.J., Saito, M.A., Kappler, A., Mojzsis, S.J., Konhauser, K.O., 2014. Cobalt and marine redox evolution. Earth Planet. Sc. Lett. 390: 253-263.

Swanner, E.D., Mloszewska, A.M., Cirpka, O.A., Schoenberg, R., Konhauser, K.O., Kappler, A., 2015. Modulation of oxygen production in Archaean oceans by episodes of Fe(II) toxicity. Nat. Geosci. 8: 126-130.

Swart, P.K., Kennedy, M.J., 2012. Does the global stratigraphic reproducibility of $\delta^{13} \mathrm{C}$ in Neoproterozoic carbonates require a marine origin? A Pliocene-Pleistocene comparison. Geology: 40: 87-90.

Thomson, D., Thomson, D., Rainbird, R.H., Rainbird, R.H., Planavsky, N., Planavsky, N., Lyons, T.W., Lyons, T.W., Bekker, A., 2015. Chemostratigraphy of the Shaler 
Supergroup, Victoria Island, NW Canada: a record of ocean composition prior to the Cryogenian glaciations. Precambrian Res. 263, 232-245.

Tossell, J.A., 2005. Calculating the partitioning of the isotopes of Mo between oxidic and sulfidic species in aqueous solution. Geochim. Cosmochim. Acta 69: 2981-2993.

Trefry, J.H., Metz, S., 1989. Role of hydrothermal precipitates in the geochemical cycling of vanadium. Nature 342: 531-533.

Trendall, A.F., 2002. The significance of iron-formation in the Precambrian stratigraphic record. Spec. Publs. Int. Ass. Sediment. 33: 33-36.

Trendall, A.F., Blockley, J.G., 1970. The iron formations of the Precambrian Hamersley Group, Western Australia with special reference to the associated crocidolite. Geological Society of Western Australia Bulletin 119: 1-366.

Tribovillard, N., Algeo, T.J., Lyons, T., Riboulleau, A., 2006. Trace metals as paleoredox and paleoproductivity proxies: An update. Chem. Geol. 232:12-32.

Tyrell, T., 1999. The relative influences of nitrogen and phosphorus on oceanic primary production. Nature 400: 525-531.

Van Kranendonk, M.J., Webb, G.E., Kamber, B.S., 2003. Geological and trace element evidence for a marine sedimentary environment of deposition and biogenicity of $3.45 \mathrm{Ga}$ stromatolitic carbonates in the Pilbara Craton, and support for a reducing Archean ocean. Geobiology 1: 91-108.

Van Kranendonk, M.J., Philippot, P., Leopt, K., Bodorkos, S., Pirajno, F., 2008. Geological setting of Earth's oldest fossils n the ca. 3.5 Ga Dresser Formation, Pilbara Craton, Western Australia. Precambrian Res. 167: 93-124.

van Zuilen, M.A., Lepland, A., Arrhenius, G., 2002. Reassessing the evidence for the earliest traces of life. Nature 418: 627-630.

Venturi, S., Donati, F.M., Venturi, A., Venturi, M., di Igiene, S., 2000. Environmental Iodine Deficiency: A Challenge to the Evolution of Terrestrial Life? Thyroid 10: 727-729.

Waldbauer, J.R., Sherman, L.S., Sumner, D.Y., Summons, R.E., 2009. Late Archean molecular fossils from the Transvaal Supergroup record the antiquity of microbial diversity and aerobiosis. Precambrian Res. 169: 28-47.

Waldron, K.J., Tottey, S., Yanagisawa, S., Dennison, C., Robinson, N.J., 2007. A Periplasmic Iron-binding Protein Contributes toward Inward Copper Supply. J. Biol. Chem. 282: 3837-3846.

Walter, M.R., Buick, R., Dunlop, J.S.R., 1980. Stromatolites 3,400-3,500 Myr old from the North Pole area, Western Australia. Nature 284: 443-445.

Whitehouse, M.J., Fedo, C.M., 2007. Microscale heterogeneity of Fe isotopes in $>3.71$ Ga banded iron formation from the Isua Greenstone Belt, southwest Greenland. Geology 35: 719-722.

Wille, M., Kramers, J.D., Nägler, T.F., Beukes, N.J., Schröder, S., Meisel, T., Lacassie, J.P., Voegelin, A.R., 2007. Evidence for a gradual rise of oxygen between 2.6 and $2.5 \mathrm{Ga}$ from Mo isotopes and Re-PGE signatures in shales. Geochim. Cosmochim. Acta 71: 2417-2435.

Williams, R.J.P., Frausto da Silva, J.J.R., 2002. The Involvement of Molybdenum in Life. Biochem. Bioph. Res. Co. 292: 293-299.

Williams, R.J.P., Frausto da Silva, J.J.R., 2003. Evolution was Chemically Constrained. J. Theor. Biol. 220: 323-343. 
Williams, R.J.P., Frausto da Silva, J.J.R., 2004. The Trinity of Life: The Genome, the Proteome, and the Mineral Chemical Elements. J. Chem. Educ. 81: 738-749.

Williams, R.J.P., Rickaby, R.E.M., 2012. Evolution's Destiny: Co-evolving Chemistry of the Environment and Life. The Royal Society of Chemistry. Cambridge, United Kingdom. p. 1-319.

Xu, Y., Shi, D., Aristilde, L., Morel, F., 2012. The effect of $\mathrm{pH}$ on the uptake of zinc and cadmium in marine phytoplankton: Possible role of weak complexes. Limnol. Oceanogr. 57: 293-304.

Zahariev, K., Christian, J.R., Denman, K.L., 2008. Preindustrial, historical, and fertilization simulations using a global ocean carbon model with new parameterizations of iron limitation, calcification, and N2 fixation. Prog. Oceanogr. 77: $56-82$.

Zegeye, A., Bonneville, S., Benning, L.G., Sturm, A., Fowle, D.A., Jones, C., Canfield, D.E., Ruby, C., MacLean, L.C., Nomosatryo, S., Crowe, S.A., Poulton, S.W., 2012. Green rust formation controls nutrient availability in a ferruginous water column. Geology 40, 599-602.

Zerkle, A.L., House, C.H., Brantley, S.L., 2005. Biogeochemical Signatures Through Time As Inferred From Whole Microbial Genomes. Am. J. Sci. 305: 467-502.

Zerkle, A.L., House, C.H., Cox, R.P., Canfield, D.E., 2006. Metal limitation of cyanobacterial $\mathrm{N}_{2}$ fixation and implications for the Precambrian nitrogen cycle. Geobiology 4: 285-297.

Zhang, X., Sigman, D.M., Morel, F.M.M., Kraepiel, A.M.L., 2014. Nitrogen isotope fractionation by alternative nitrogenases and past ocean anoxia. Proc. Natl. Acad. Sci. 111: 4782-4787.

Zhang, S., Wang, X., Wang, H., Bjerrum, C.J., Hammarlund, E.U., Costa, M.M., Connelly, J.N., Zhang, B., Su, J., Canfield, D.E., 2016. Sufficient oxygen for animal respiration 1,400 million years ago. Proc. Natl. Acad. Sci. USA 113: 17311736.

Zhou, X., Thomas, E., Rickaby, R.E., Winguth, A.M. and Lu, Z., 2014. I/Ca evidence for upper ocean deoxygenation during the PETM. Paleoceanography, 29: 964-975.

Zhou, X., Jenkyns, H.C., Owens, J.D., Junium, C.K., Zheng, X.Y., Sageman, B.B., Hardisty, D.S., Lyons, T.W., Ridgwell, A., Lu, Z., 2015. Upper ocean oxygenation dynamics from $\mathrm{I} / \mathrm{Ca}$ ratios during the Cenomanian-Turonian OAE 2. Paleoceanography 30: 510-523. 


\section{Figures}

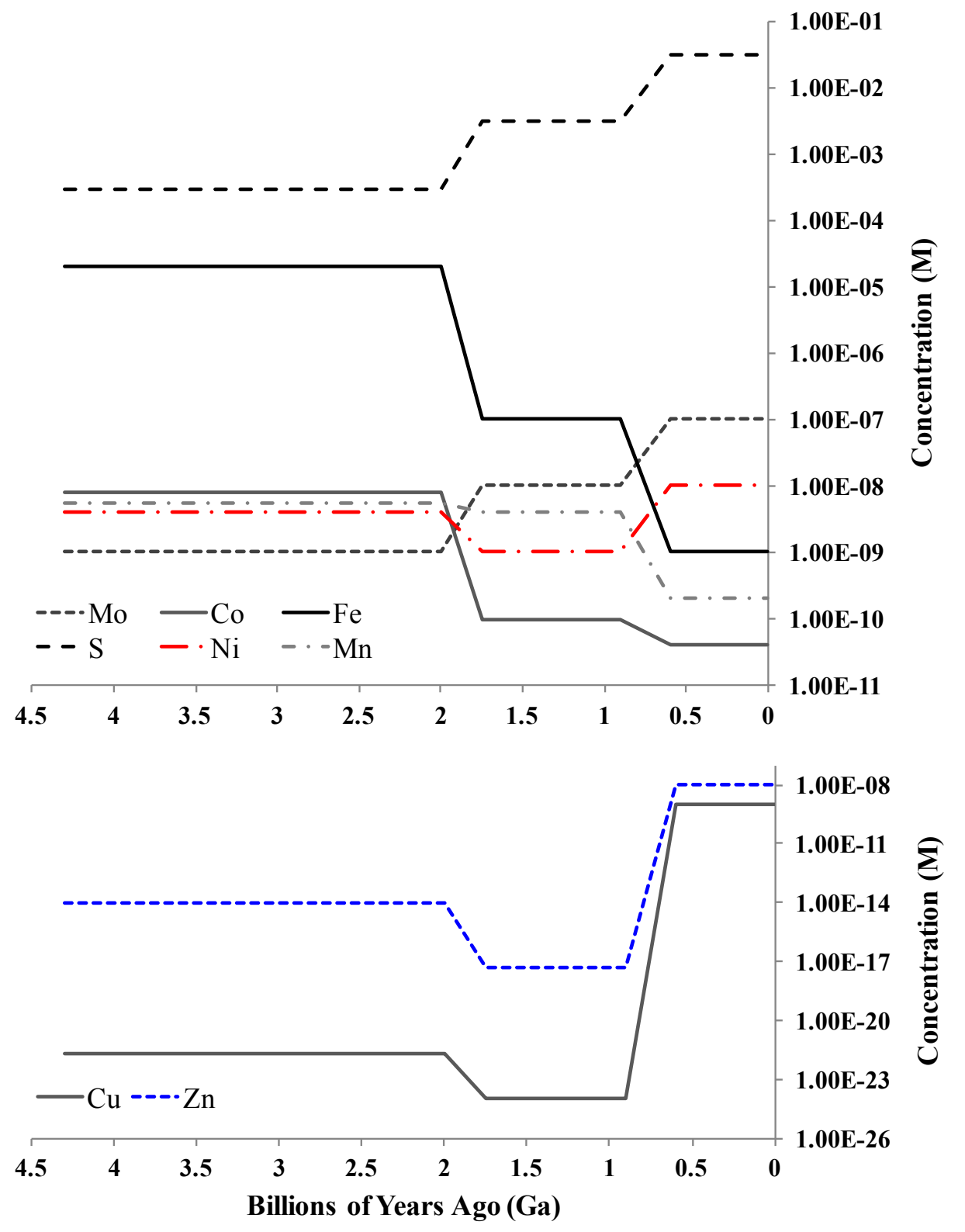

Figure 1. Approximate trace element concentrations though time based on previous geochemical modeling and genomic inferences. This traditional view of temporal trace element evolution is largely adapted from the work of Saito et al. (2003), except for Mo which was based on the ocean box models of Anbar and Knoll (2002), and has been further discussed by Zerkle et al. (2005) and Anbar (2008). Highlighted are nickel (red) and zinc (blue) whose patterns in the rock record diverge greatly from these modeling and genomic suggestions and are discussed in detail below. 


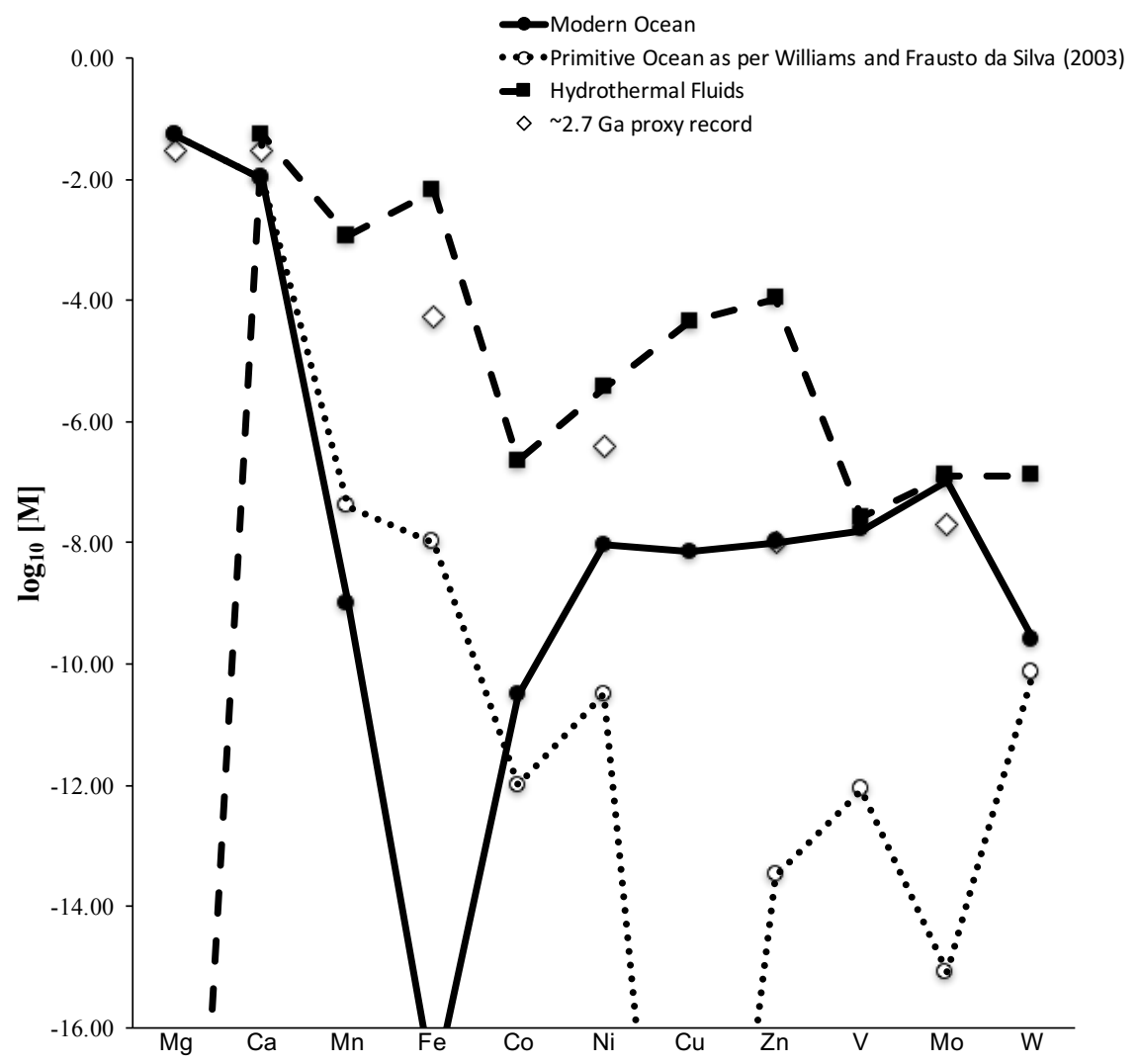

Figure 2.

Updated version of a classic figure from Williams and Frausto da Silva (2003; their figure 4), highlighting the concentration of selected elements in the modern ocean (Elderfield and Schultz, 1996; Williams and Frausto da Silva, 2003; Scott et al., 2008; Konhauser et al., 2009), the primitive ocean (as per Williams and Frausto da Silva, 2003), hydrothermal fluids (Trefry and Metz, 1989; Elderfield and Schultz, 1996; Douville et al., 2002; Kishida et al., 2004), and values based on the proxy record for $\sim 2.7 \mathrm{Ga}$ (Jones et al., 2015; Scott et al., 2008; Konhauser et al., 2009; Scott et al., 2013; Robbins et al., 2013). Clear differences exist between the predicted primitive ocean values of Williams and Frausto da Silva (2003), who based their estimates off of sulfide mineral solubility, and those indicated by the proxy record. Some proxy records exhibit values more typical of hydrothermal fluids, possibly indicating a greater relative contribution from hydrothermal sources to the early oceans (e.g., Robbins et al., 2013). 


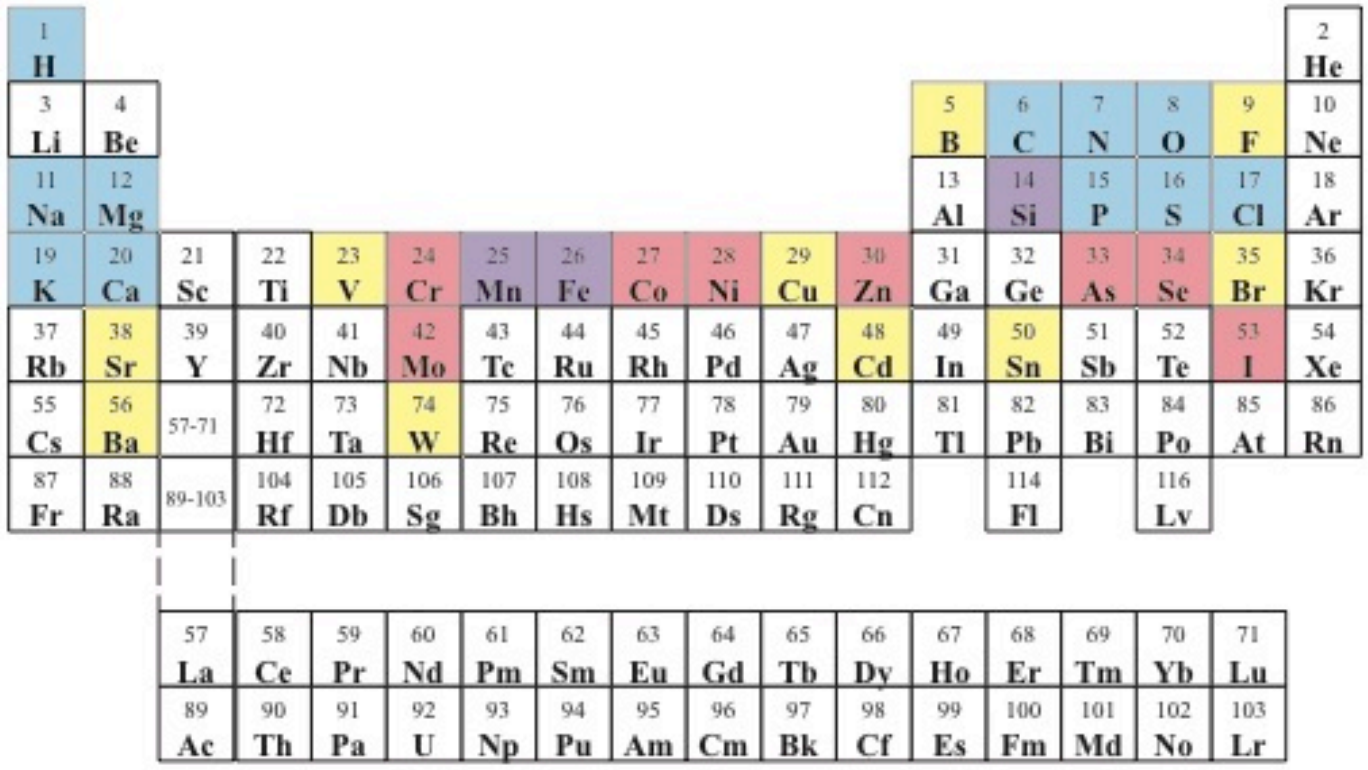

Figure 3. The periodic table of elements showing biologically essential elements as identified by Frausto da Silva and Williams (2001), and highlighting those that have been investigated in the sedimentary record to date. Blue indicates major bioessential elements, yellow - bioessential trace elements that have not been investigated in the proxy record, purple - major elements with biological importance whose general seawater geochemical behavior is fairly well known, and red - trace elements investigated in at least one of the sedimentary proxy records, such as IF, black shales, sedimentary pyrite, and/or carbonates. 


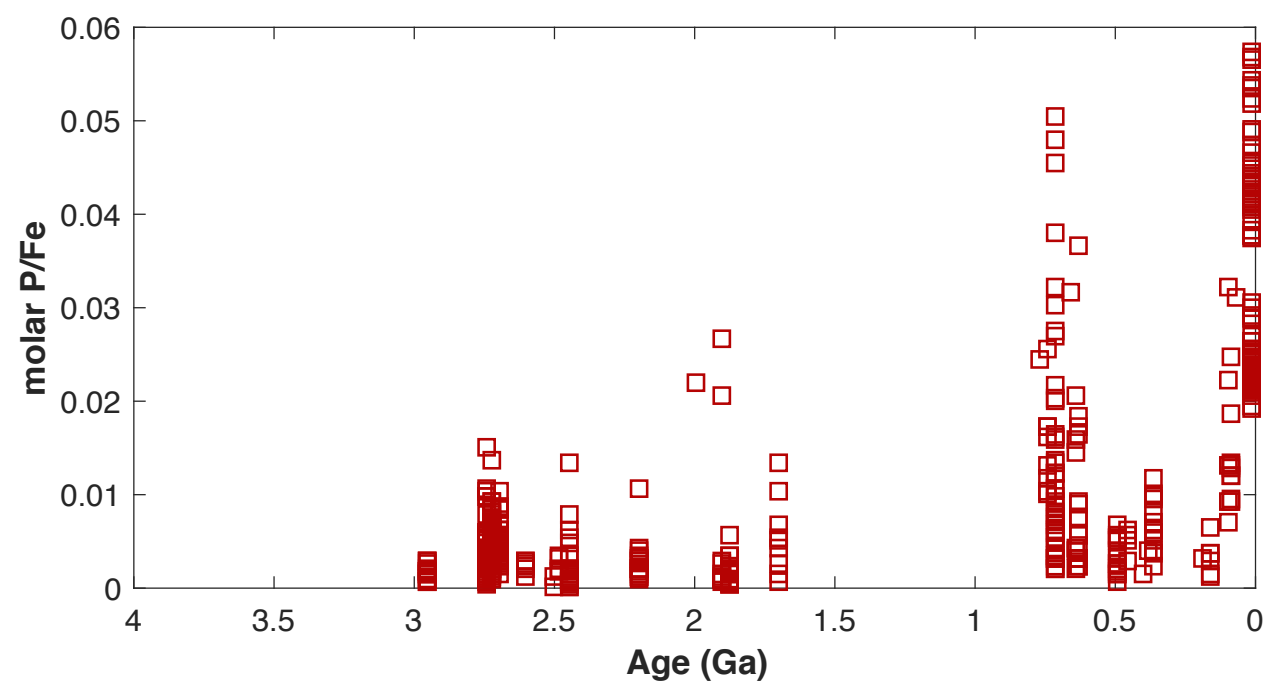

Figure 4. Molar $\mathrm{P}$ to $\mathrm{Fe}$ ratios in iron formations through time. Reproduced from Planavsky et al. (2010b). Although several partitioning scenarios and coefficients have been proposed (see Bjerrum and Canfield, 2002; Konhauser et al., 2007; Planavksy et al., 2010b; and Jones et al., 2015) the concentration of $\mathrm{P}$ in the oceans in deep time remains a matter of ongoing debate. 


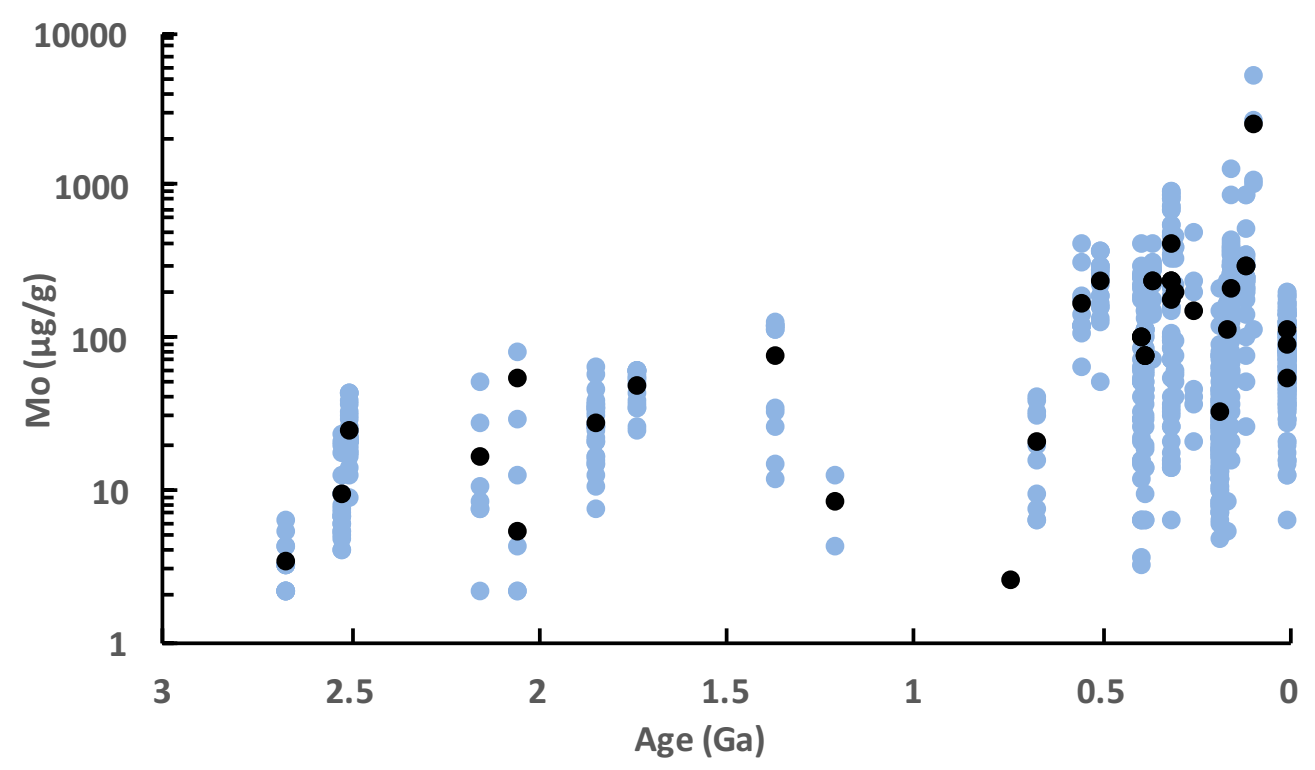

Figure 5. Molybdenum in black shales through time. The Mo record in black shales shows a relatively systematic increase through time, with a minor spike near the GOE, followed by a decrease in the Paleoproterozoic and Mesoproterozoic, and an increase in the Neoproterozoic to modern. This can be seen in the range of values recorded (blue) as well as formation average (black). This plot is a variation of data presented in Reinhard et al. (2013b). 


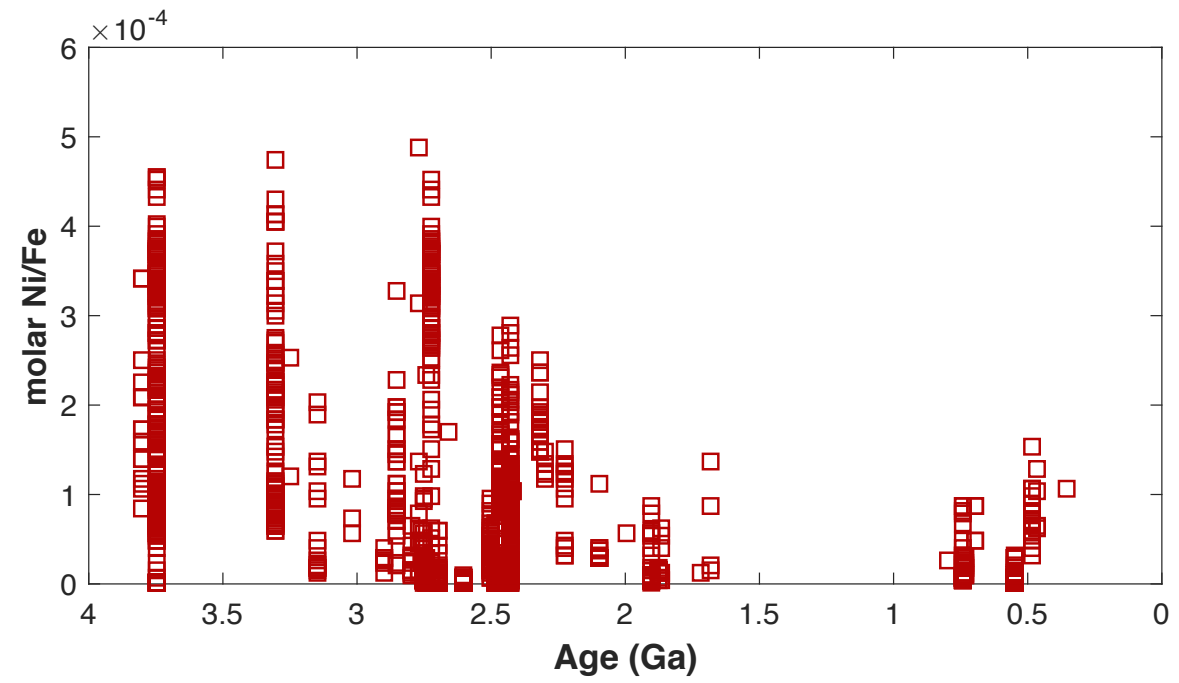

Figure 6. Molar $\mathrm{Ni}$ to $\mathrm{Fe}$ ratios in iron formation through time. This dataset has most recently been updated by Konhauser et al. (2015), who nearly doubled the points available since its initial presentation in Konhauser et al. (2009). A unidirectional decline in molar $\mathrm{Ni} / \mathrm{Fe}$ is stark and robust. A similar trend is observed in the pyrtie record as presented by Large et al. (2014), however, some variability in the Phanerozoic is observed in the pyrite record that is not present in the IF record. 


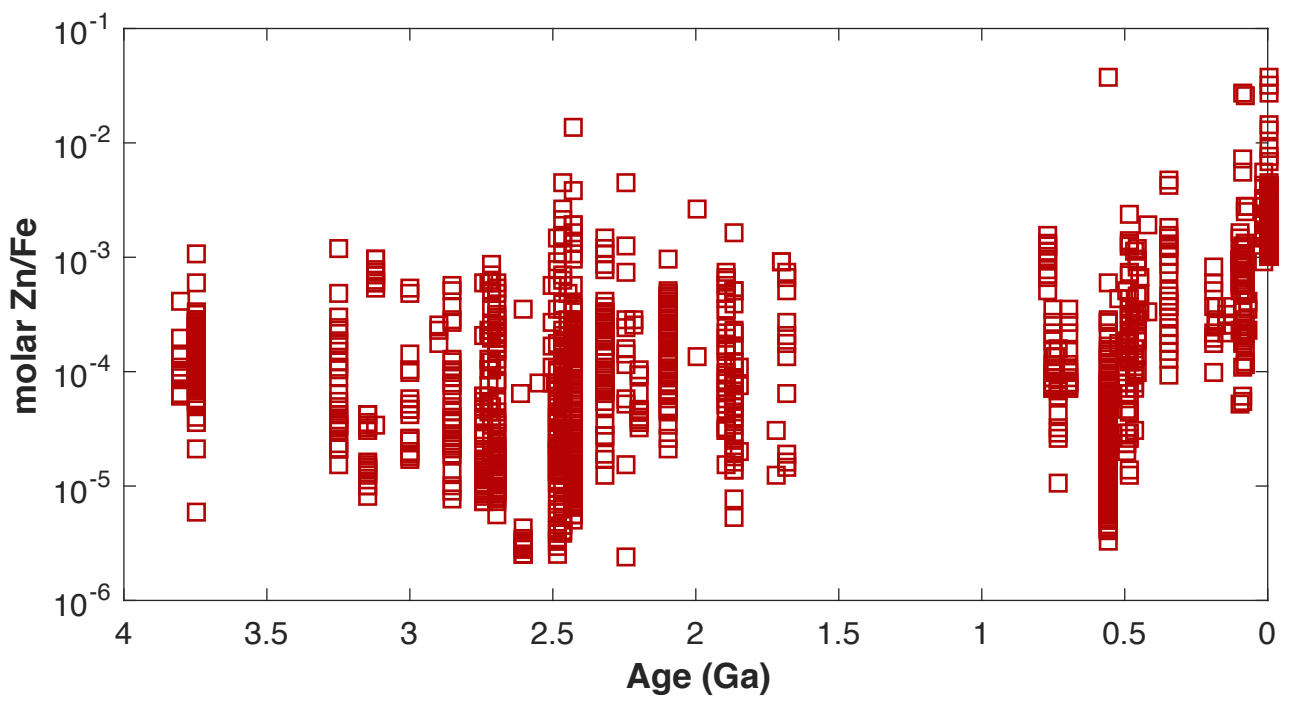

Figure 7. Concentrations of $\mathrm{Zn}$ in iron formation through time (reproduced from Robbins et al., 2013). This version includes all available IF data and is plotted without the removal of samples indicating detrital contamination (i.e., $>1 \% \mathrm{Al}_{2} \mathrm{O}_{3}$ or $>0.1 \% \mathrm{TiO}_{2}$ ). Even when the all samples are included, $\mathrm{Zn} / \mathrm{Fe}$ ratios in IF tend to fall in a field that spans 2-3 orders of magnitude and is relatively consistent through time. The only notable deviation from this long term trend is the most modern samples, which are may be reflective of local $\mathrm{Zn}$ enrichment in near-vent hydrothermal exhalative sediments. See Robbins et al. (2013) for further discussion. 


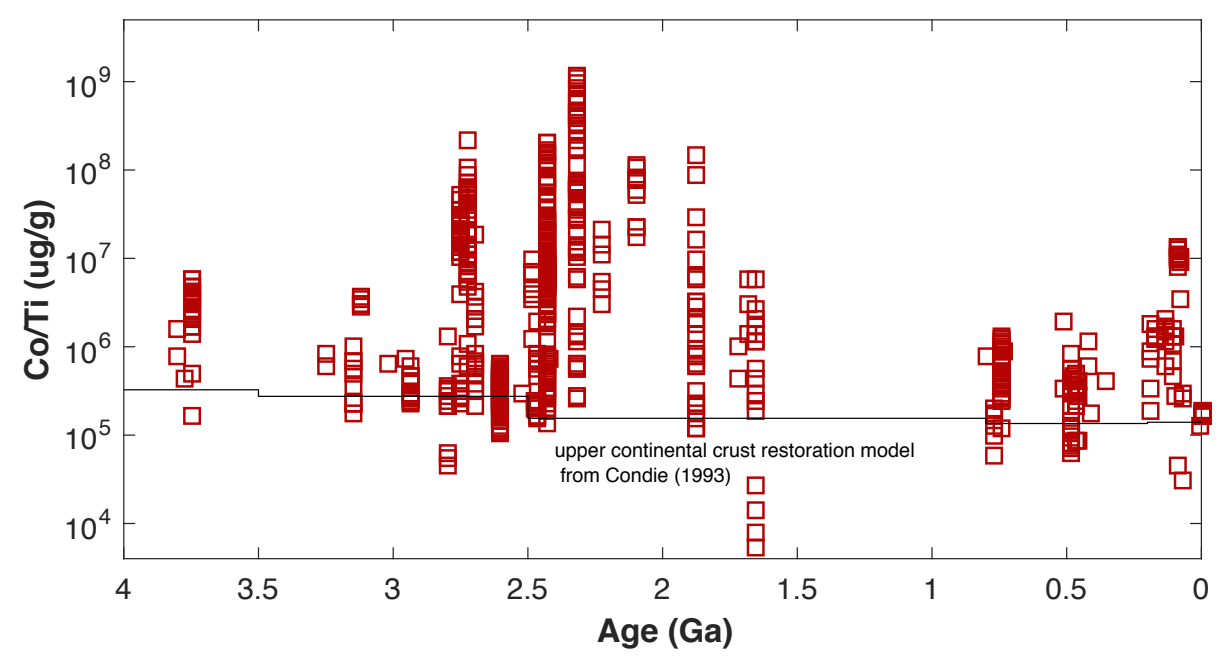

Figure 8. Molar cobalt to titanium ratios normalized to evolving continental crust through time. Normalization was performed using the upper continental curst restoration model of Condie (1993). The $\mathrm{Co} / \mathrm{Ti}$ trend shows an expansion of authigenic Co enrichments in iron formations between $\sim 2.8-1.8 \mathrm{Ga}$. Replotted from Swanner et al. (2014). 


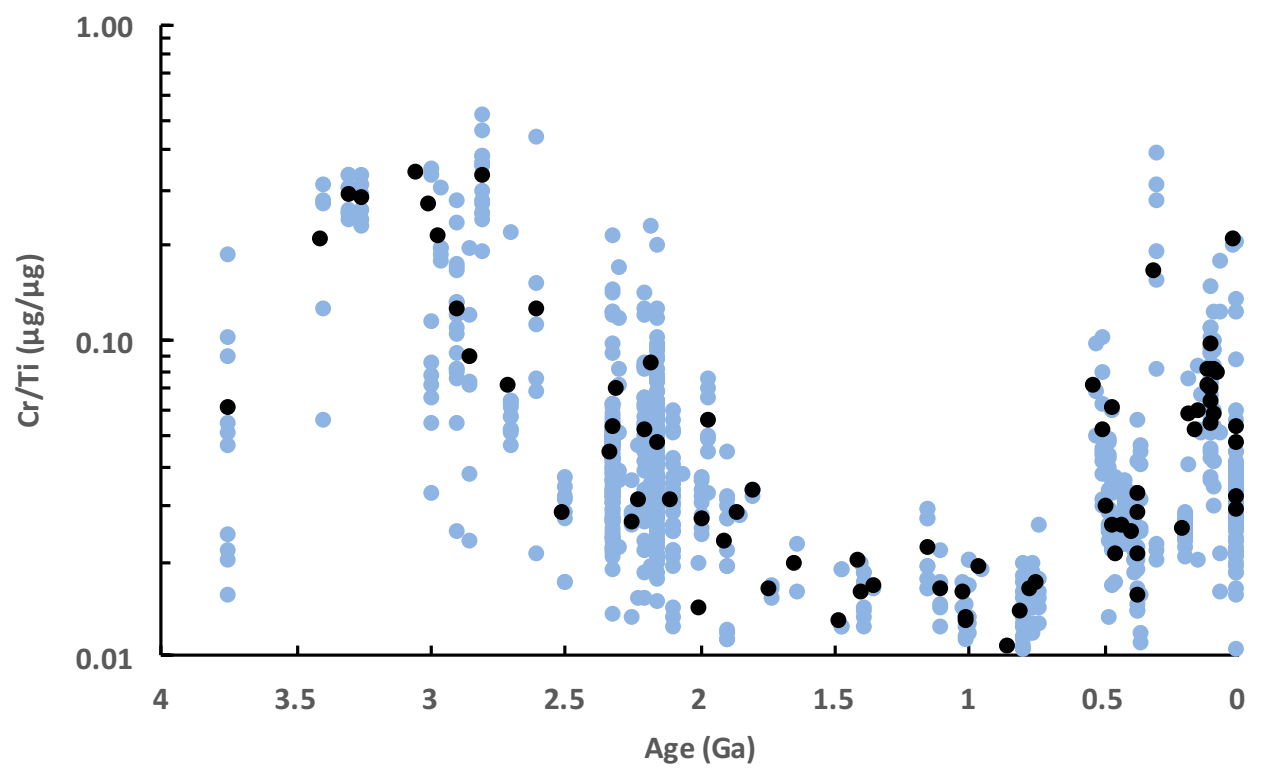

Figure 9. Chromium abundances in black shales normalized to titanium $(\mu \mathrm{g} / \mu \mathrm{g})$, reflecting authigenic $\mathrm{Cr}$ enrichments though time. Replotted from Reinhard et al. (2013b). The $\mathrm{Cr}$ record in black shales has two interesting features worth highlighting. First, there is a decline in the Archean to Proterozoic, similar to the shale matrix record of Large et al. (2014), which has been attributed to a change in the abundance of ultramafic source rocks. Second, muted enrichments characterize the Mesoproterozoic, which have been attributed to pervasive anoxia (Reinhard et al., 2013b). 


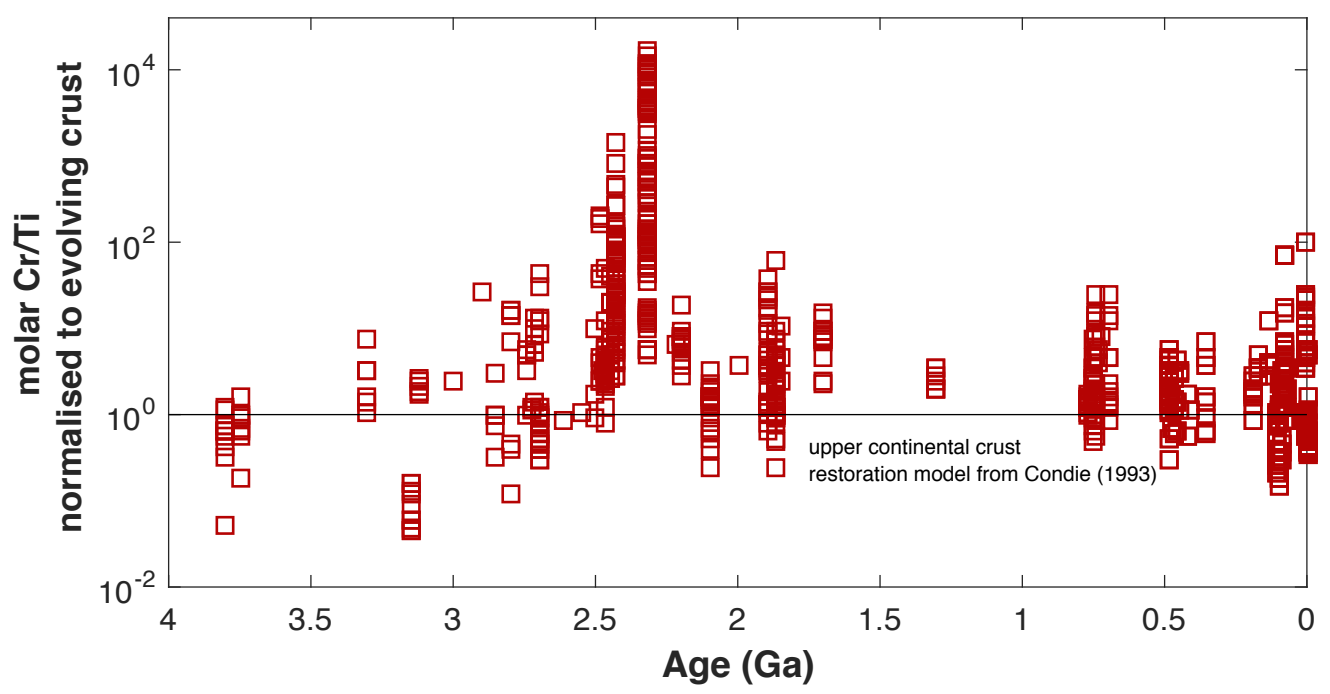

Figure 10. Authigenic Cr enrichments in the IF record. Here a peak in molar $\mathrm{Cr} / \mathrm{Ti}$ ratios is observed at $2.4 \mathrm{Ga}$ and has been interpreted to reflect acid mine drainage cause by massive oxidation of pyrite by aerobic bacteria on land around the time of the GOE. The data, normalized to the upper continental restoration model of Condie (1993), has been replotted from Konhauser et al. (2011). 


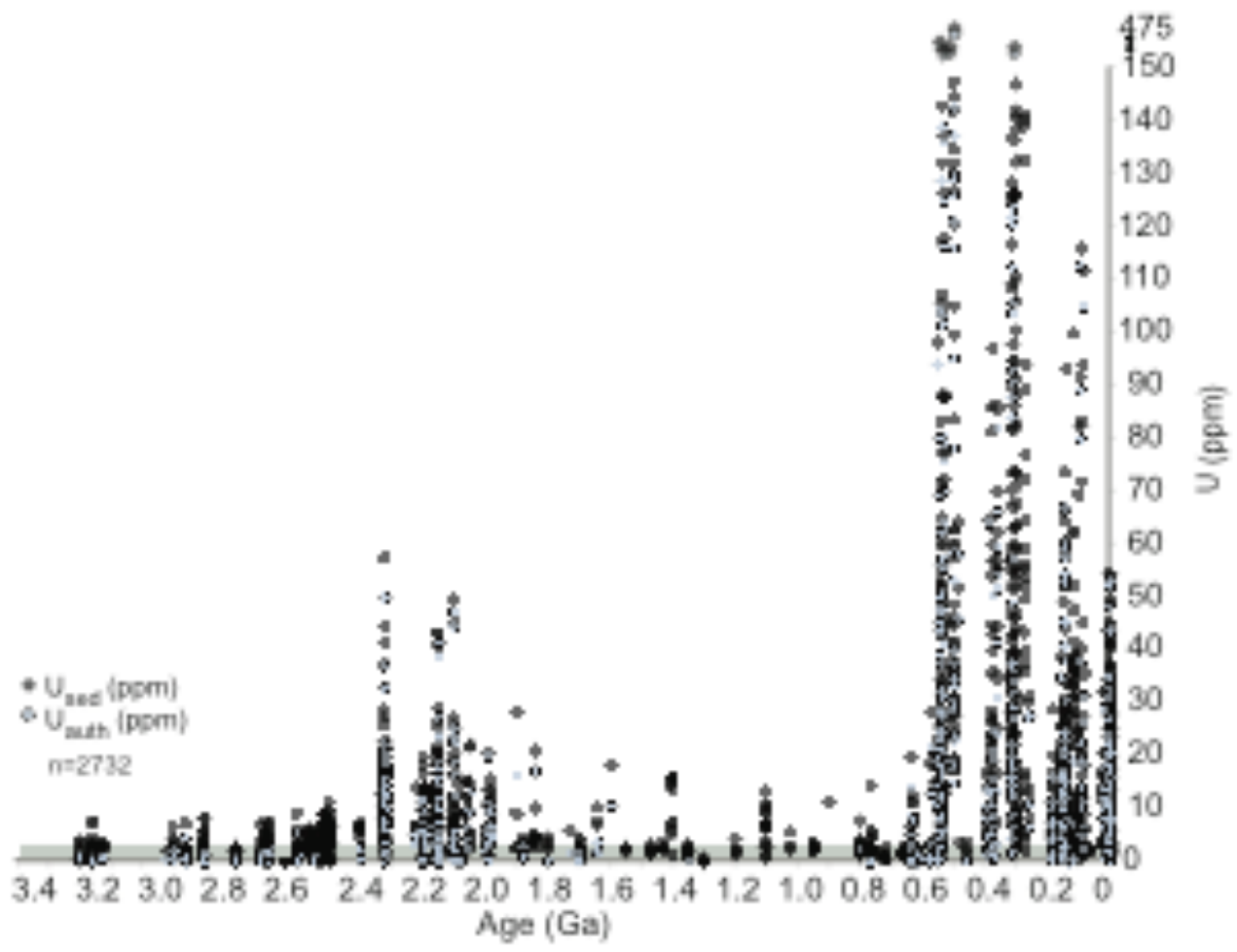

Figure 11. Sedimentary and authigenic $U$ enrichments in black shales through time adapted from Partin et al. (2013b). The grey bar signifies the U concentration of average continental crust. This record has been interpreted to reflect the evolution of atmospheric oxygen, with an increase in U, delivered by oxidative weathering, between 2.4 and $2.0 \mathrm{Ga}$ corresponding to the GOE and a subsequent fall to low oxygen levels in the Paleoproterozoic, before the drastic increase in $U$ enrichments corresponding to Neoproterozoic oxygenation. 

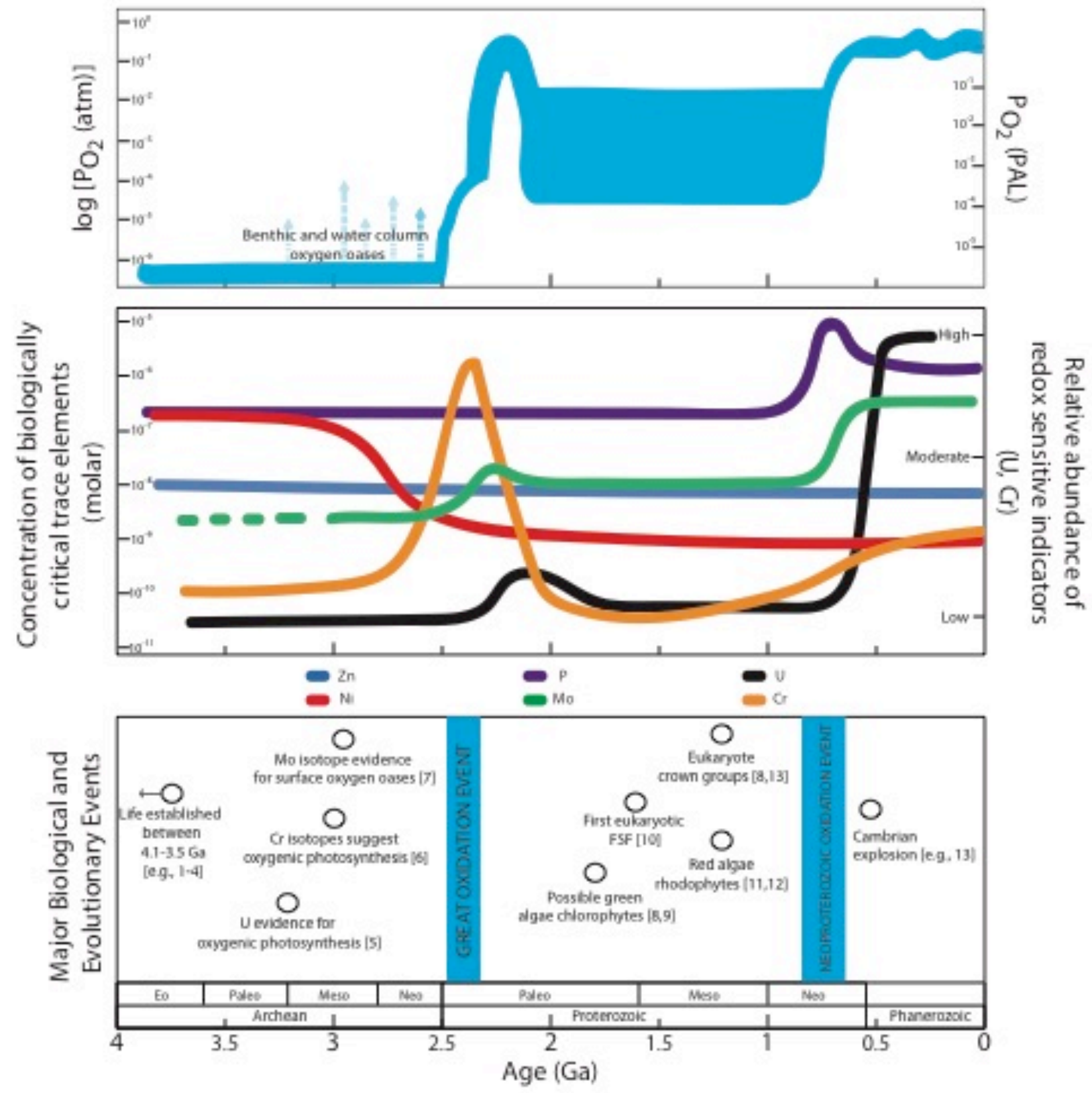

Figure 12. The top panel shows a recently refined view on the evolution of oxygen levels in the atmosphere-ocean system through time as described Lyons et al. (2014a). Whiffs of oxygen prior to $2.7 \mathrm{Ga}$ may be attributed to the photosynthetic activity of benthic microbial mats as per Lalonde and Konhauser (2015) and water column oxygen oases as per Olson et al. (2013). The middle panel highlights a relatively conservative view on trace element abundances in the early ocean based on insights from the sedimentary records: Zn (blue), Ni (red), Mo (green), P (purple), U (black) and Cr (orange). For elements with low concentration in seawater where estimates of the seawater reservoir size have been offered ( $\mathrm{Zn}, \mathrm{Ni}, \mathrm{Mo}$ and $\mathrm{P})$, molar concentrations have been indicated, 
while for redox-sensitive elements $(\mathrm{Cr}$ and $\mathrm{U})$, relative rock abundance has been indicated on the secondary vertical axis. References used in the compilation of this view are highlighted in the text discussing the respective elements. The bottom panel provides a timeline highlighting key geochemical and biological evolutionary events between $4 \mathrm{Ga}$ and present. Indicated are notable geochemical and biological events involving trace elements, [\#] beside each event corresponds to the following references. [1] Bell et al. (2015). [2] Mojzsis et al. (1996). [3] Rosing (1999). [4] Furnes et al. (2004). [5] Satkoski et al. (2015). [6] Crowe et al. (2013). [7] Planavsky et al. (2014b). [8] Knoll (2014). [9] Moczydłowska et al. (2011). [10] Dupont et al. (2010). [11] Butterfield (2000). [12] Knoll et al. (2013). [13] Erwin et al. (2011). For reviews on the Great Oxidation Event and Neoproterozoic Oxidation Event, see Farquhar et al. (2011), Lyons et al. (2014a) and Bekker (2014). 